NBER WORKING PAPER SERIES

\title{
THE SHORT-AND LONG-TERM CAREER EFFECTS OF GRADUATING IN A RECESSION: HYSTERESIS AND HETEROGENEITY IN THE MARKET FOR COLLEGE GRADUATES
}

\author{
Philip Oreopoulos \\ Till von Wachter \\ Andrew Heisz \\ Working Paper 12159 \\ http://www.nber.org/papers/w12159 \\ NATIONAL BUREAU OF ECONOMIC RESEARCH \\ 1050 Massachusetts Avenue \\ Cambridge, MA 02138 \\ April 2006
}

We would like to thank David Card, Ken Chay, Pierre-André Chiappori, Damon Clark, John DiNardo, David Figlio, David Lee, Justin McCrary, Bentley McLeod, Daniel Parent, Mike Riordan, Eric Verhoogen, and participants at the NBER Summer Institute 2005 and at seminars in UC Berkeley, Cornell, UCLA, Stanford, Columbia University, University of British Columbia, University of Maryland, University of Michigan, University of Florida, the Bank of Italy, and Tor' Vergata for helpful comments. All remaining errors are our own. Corresponding author: Till von Wachter vw2112@ columbia.edu. The views expressed herein are those of the author(s) and do not necessarily reflect the views of the National Bureau of Economic Research.

(C2006 by Philip Oreopoulos, Till von Wachter and Andrew Heisz. All rights reserved. Short sections of text, not to exceed two paragraphs, may be quoted without explicit permission provided that full credit, including $\odot$ notice, is given to the source. 
The Short- and Long-Term Career Effects of Graduating in a Recession: Hysteresis and Heterogeneity in the Market for College Graduates

Philip Oreopoulos, Till von Wachter and Andrew Heisz

NBER Working Paper No. 12159

April 2006

JEL No. J0, J3, J6, E3

\begin{abstract}
$\underline{\text { ABSTRACT }}$
The standard neo-classical model of wage setting predicts short-term effects of temporary labor market shocks on careers and low costs of recessions for both more and less advantaged workers. In contrast, a vast range of alternative career models based on frictions in the labor market suggests that labor market shocks can have persistent effects on the entire earnings profile. This paper analyzes the long-term effects of graduating in a recession on earnings, job mobility, and employer characteristics for a large sample of Canadian college graduates with different predicted earnings using matched university-employer-employee data from 1982 to 1999, and uses its results to assess the importance of alternative career models. We find that young graduates entering the labor market in a recession suffer significant initial earnings losses that eventually fade, but after 8 to 10 years. We also document substantial heterogeneity in the costs of recessions and important effects on job mobility and employer characteristics, but small effects on time worked. These adjustment patterns are neither consistent with a neo-classical spot market nor a complete scarring effect, but could be explained by a combination of time intensive search for better employers and long-term wage contracting. All results are robust to an extensive sensitivity analysis including controls for correlated business cycle shocks after labor market entry, endogenous timing of graduation, permanent cohort differences, and selective labor force participation.
\end{abstract}

Philip Oreopoulos

Department of Economics

University of Toronto

150 St. George Street

Toronto, ON M5S 3G7

Canada

and NBER

oreo@economics.utoronto.ca

Till von Wachter

Columbia University

1022 International Affairs Building

420 West 118th Street

New York, NY 10027

www.columbia.edu/ vw2112
Andrew Heisz

Statistics Canada - Analytical Studies Branch 120 Parkdale Avenue

24th Floor, R.H. Coats Building

Ottawa, Ontario K1A 0T6

Canada

andrew.Heisz@statcan.ca 


\section{Introduction}

In the standard neo-classical view, labor markets function like perfectly competitive spot markets and any effects of bad luck - such as from a labor demand shock or a recession - are temporary and inconsequential for wages and career development (Friedman 1953). In such a setting, lasting wage differences among similar workers arise from leisure preferences or from choices over human capital acquisition, rather than luck (Mincer 1974). Within this framework, typical estimates imply small welfare costs of recessions (Lucas 1987). On the other extreme, models based on institutional wage setting or segmented labor markets predict that temporary shocks can have permanent consequences, especially for less advantaged workers (Doeringer and Piore 1971, Okun 1973). More recent theoretical models of wage determination based on job search (Burdett 1978, Topel and Ward 1992), contracting (Harris and Holmstrom 1982, Macleod and Malcolmson 1994), or efficiency wage considerations (Akerlof and Yellen 1985, Acemoglu 2001) also emphasize the role of frictions in the labor market, but predict persistent, not permanent, negative effects on career outcomes from temporary labor market shocks.

Recent empirical work uses exogenous variation in economic conditions to test directly for the shortand long-term effects of luck (Bertrand and Mullainathan (2001) for CEOs; Baker, Gibbs, and Holmstrom (1994) for workers at a large firm; Jacobson, Lalonde, and Sullivan (1993) for workers displaced by mass layoffs; Welch (1979) and Freeman (1979) for workers in large cohorts). Although these studies find that certain groups of workers experience highly persistent effects from random luck, it may be difficult to generalize these findings to the effects caused by a commonly recurring labor market shock - such as a recession - and for a more representative group of workers. However, another strand of recent literature, based on more representative samples of the labor market, suggests that frictions play an important role in the wider labor market as well, with job mobility (Topel and Ward 1992, Neal 1999), wage differentials (Dickens and Katz 1987, Krueger and Summers 1988, Abowd, Creecy, and Kramarz 2002) and long-term job attachment (Farber 1999, Gibbons and Waldman 1999) all playing an important role. Alternative models implied by these stylized facts have starkly different predictions on the long-term effect of short term labor market shocks. However, few papers have used variation from recessions to learn about the role of frictions in the labor market, and whether such shocks and frictions affect some workers more than others. ${ }^{2}$

In this paper, we analyze the short- and long-term effects of graduating in a recession on college graduates with different educational backgrounds using an unusual match between administrative universityemployee-employer data from Canada. We thereby fill three important gaps in the literature. First, we analyze the effect of a typical recurring shock - economic downturns - affecting a large group of workers, while

\footnotetext{
${ }^{2}$ Important exceptions are Beaudry and DiNardo (1991) and some of the literature on 'scarring,' further discussed below. Although a long literature assesses the current effects of recessions for low-income workers, little is known about the long-term effects (e.g., Hines, Hoynes, and Krueger 2002, Cutler and Katz 1991).
} 
minimizing the confounding effects of correlated shocks in the labor market or selection. Second, we use the detailed longitudinal information on employment, job mobility, and employer characteristics covering a horizon of ten years to assess the empirical relevance of competing models that predict persistent effects of early labor market conditions. Third, unique information about an individual's school and academic program allows us to investigate whether workers predicted to earn less suffer larger long-term losses and adjust differently to an initial shock.

Young workers are an ideal group to study the importance of 'luck', since they may be particularly affected by temporary labor market conditions (Katz and Autor 1999, Freeman 1979, Okun 1973). ${ }^{3}$ Since labor market entrants have similar prior labor market experience, they are affected by luck in a comparable moment of their career and can be more easily categorized into more and less advantaged groups based on their university background. ${ }^{4}$ In addition, the unique data set at our disposition allows us to address several important empirical challenges inherent in estimating the long-term impact from initial labor market shocks. First, the distinction between temporary and persistent shocks is crucial to isolate the role of luck. The broad range of cohorts in our sample yields sufficient variation to isolate the effect of the very first labor market conditions. Second, typically there are too few recurring labor market shocks affecting large groups of similar workers. Our data cover almost the universe of 20 years of graduating cohorts encompassing two large recessions with differential strength across ten regions. ${ }^{5}$ Third, detailed information on longitudinal employment patterns and the timing of college entry and exit allows us minimize the confounding effects from selective participation or graduation.

This is the first paper to use matched university-employer-employee data to systematically analyze the effects of initial luck on the entire process of dynamic adjustment for a large number of cohorts and groups of college graduates with different earnings capacities. Our results suggest three main findings. First, luck matters - graduating in a recession leads to large initial earnings losses that do fade, but slowly and over an eight to ten year period after graduation. A typical recession -- a rise in unemployment rates by five

\footnotetext{
${ }^{3}$ During the first 10 years of work, individuals experience $70 \%$ of overall wage growth, cha nge jobs frequently, and find a career occupation and employer (Murphy and Welch 1990, Topel and Ward 1992). In this formative period young workers are particularly at risk of earnings losses (Blanchflower and Oswald 1994), job losses (Farber 2003), and unemployment (Ryan 2001) from a recession. Similarly, a long literature documents how disadvantaged workers are hurt most in recessions and may gain most in expansions (e.g., Hines, Hoynes, and Krueger 2002, Freeman 2001).

${ }^{4}$ For more mature workers, hard-to-observe differences in on-the-job experience, training, and job levels may not be approximated well by potential labor experience. Thus, a labor market shock at a given year of potential experience may affect them at different points in their actual career development and at different skill levels. Similarly, college background is a worse predictor of potential earnings as workers accumulate experience.

${ }^{5}$ Several previous studies on the persistent effects of aggregate labor market conditions have used the Panel Study of Income Dynamics (Devereux 2003) and the National Longitudinal Studies of Youth (Gardecki and Neumark 1998, Neumark 2002, Kahn 2005). While providing detailed survey information on careers and worker demographics, the small samples of these data sets do not allow controlling for cohort, state, and year effects, controlling for persistent correlated labor market conditions, or studying other career outcomes than wages with sufficient degree of precision. Moreover, often the range of cohorts studied covers a limited range of business cycles. For example, Kahn's (2005) careful study of white male college graduates can exploit longitudinal information on somewhat more than 500 workers graduating around one major recession (1982).
} 
percentage points in our context -- implies an initial loss in earnings of about 9 percent that halves within 5 years and finally fades to zero by 10 years. This result is robust to the use of both national and regional unemployment rates, does not appear to arise due to correlation with labor market shocks occurring later in workers' careers, and does not seem to be due to selective employment and graduation decisions.

Second, initial random shocks affect the entire career profile, including systematic changes in job mobility and firm characteristics. We find that temporary reductions in the quality of the first employer can explain $30-40 \%$ of initial earnings losses. The dynamic adjustment process is characterized by increased mobility across employers and industries and improvements in average firm characteristics, but little effects on employment or time worked. Only workers with the lowest predicted earnings are permanently downranked to firms paying lower wages. We also find an important degree of persistence of unemployment rate shocks within firms, especially for very large and high paying employers.

Third, some workers are more affected by luck than others. In particular, earnings losses from temporarily high unemployment rates are strongest for labor market entrants and small for workers with two or more years of labor market experience. Among graduates, those at the bottom of the wage distribution and those with the lowest predicted earnings suffer significantly larger and much more persistent earnings losses than those at the top. Thus, we see a temporary increase in inequality from recessions lasting up to ten years and lasting increases in inequality in the present discounted value of earnings.

For all but the most disadvantaged workers, these findings appear inconsistent with the "long-term scarring" view of the labor market. Yet, the "perfect spot market" model of labor market may only be a good approximation in the very long run (a time horizon of 10 years). In the short- to-medium run the observed patterns of job mobility and firm characteristics imply a process of time-intensive job search in the presence of wage differentials (e.g., Okun 1973, Krause and Lubik 2005). In such an environment, least able workers are hurt most in recessions as firms raise their hiring standards (e.g., Hall 1974), consistent with what we find. ${ }^{6}$ Yet, job search alone cannot explain differences in the effects between labor market entrants and more mature workers, and the finding that cyclical effects are more persistent for workers starting to work at large, high-paying employers. These differences may be due to the presence of long-term implicit contracts (Harris and Holmstrom 1982), or due to cyclical job assignment and differences in on-the-job training (Gibbons and Waldman 2004). Overall, it seems that a combination of search and contracting models is necessary to fully explain patterns of recovery from temporary demand shocks seen in our data.

Our paper contributes to several recent strands of literature. By examining the long-term effects of a typical labor market shock free of confounding effects from persistent shocks and selection for a representative number of cohorts, a wide range of career outcomes, and workers of different experience and ability, it extends the existing literature documenting that luck can matter for single occupations (Betrand and

\footnotetext{
${ }^{6}$ However, also consistent with our results is a process of sequential sorting with employer learning as in Gibbons, Katz, Lemieux, and Parent (2005) in which workers are sorted into high-wage firms (Fox 2004).
} 
Mullainathan 2001, Oyer 2005), for job losers (Jacobson, Lalonde, and Sullivan 1993, von Wachter and Bender 2005), or for single cohorts of workers (Freeman 1975, Welch 1979, Kahn 2005).

This is also one of the few papers showing that job mobility and employer characteristics respond systematically to exogenous labor market shocks (von Wachter and Bender 2006). It thereby extends earlier studies on the role of job search without access to exogenous variation or detailed information on employers (Topel and Ward 1992); studies on the effect of unemployment shocks within firms (Beaudry and DiNardo 1991, Baker, Gibbs, and Holmstrom 1994); and studies suggesting an important role of industry and firm characteristics in wage determination (e.g., Dickens and Katz 1987, Krueger and Summers 1988, Abowd, Creecy, and Kramarz 2002). ${ }^{7}$

Our paper also contributes to two strands of literature in macroeconomics. First, while macroeconomists typically measure the cost of recessions for a representative worker (Lucas 1987), 8 a large literature suggests that less able workers may be hurt most in recessions (e.g., Hines, Hoynes, and Krueger 2002, Freeman 2001). Our data allows us to provide actual estimates of the change in the present discounted value of earnings due to a recession for more and less advantaged workers. Second, our evidence on the response of wage setting and job mobility to recessions suggests an important role of search frictions in generating cyclical labor market dynamics (Hall 2005, Shimer 2005), but also suggests an important role for mobility across firms and sectors (Krause and Lubik 2005) and long-term wage contracts (Beaudry and DiNardo 1991).

The rest of the paper is organized as follows. Section 2 gives an overview of relevant models of career determination. Section 3 outlines the empirical strategy we use to address these questions and our approach to deal with selective labor market entry, selective labor force participation, and the presence of correlated unemployment shocks. The main results on earnings, employment, job mobility, and firm characteristics are discussed in Section 4, followed by an analysis of heterogeneity. A detailed sensitivity analysis addressing among others the question of selection and omitted variable bias due to recurring aggregate unemployment conditions is summarized in the Appendix. The sixth section discusses our results in light of different models of dynamic adjustment. The last section concludes.

\section{Models of Career Determination}

The following section briefly reviews the main models of career determination that have guided the interpretation of our results. Although most features of these models are relevant for the full labor market, we focus the discussion on young workers who may be hurt most by conditions in the external labor market

\footnotetext{
${ }^{7}$ By analyzing workers' adjustment patterns to a recession shock, it also contributes to the recent macroeconomic literature on job and earnings dynamics over the business cycle (e.g., Hall 2005, Shimer 2005, Krause and Lubik 2005).

${ }^{8}$ Lucas' original measure asked how much additional consumption would make workers indifferent between economies with and without consumption risk based. More recent papers distinguish between individuals with and without wealth holdings, or between workers on the job and those laid-off (see, e.g., Barlevy 2005 for an excellent survey).
} 
(e.g., Freeman 1975, Katz, Loveman, and Blanchflower 1995, Katz and Autor 1999). ${ }^{9}$ Existing results indeed suggest young workers may be hurt most by recessions, but little is known about the degree of persistence of these losses. ${ }^{10}$

As a common benchmark, the neo-classical model of wage determination with or without human capital accumulation does not predict long-term effects from short term labor market shocks. Without human capital accumulation, the basic neo-classical model predicts earnings should only depend on current labor market conditions in similar fashion for all age groups, and long-term effects of early labor market conditions only arise due to correlated persistent labor market shocks. ${ }^{11}$ If human capital accumulation occurs on the job (e.g., Mincer 1974), long spells of non-employment or reduced working hours initially lower earnings growth for younger workers. However, the standard model has difficulty explaining lasting effects of recessions that involve short spells of unemployment as typically observed for young college graduates. Extensions of the standard model assign a role to the accumulation of firm specific capital (e.g., Becker 1964) or industry specific capital (e.g., Neal 1995). If persistent early labor market conditions lead to increased job mobility, workers may initially accumulate less specific human capital, and catch up by finding stable employment in a firm or industry. ${ }^{12}$

Some more recent models of career determination imply that even temporarily adverse labor market conditions can have persistent effects, particularly for workers who just entered the labor market. As opposed to the 'standard human capital' view, these could be broadly termed the 'contracting' or 'within firm' view, and the 'search' or 'between firm' view. The full implications from these models for the pattern of adjustment to labor market shocks have not been fully exploited in the literature.

Among the several variants of the 'within firm' view (e.g., Prendergast 1999, Gibbons and Waldman 1999), two are particularly relevant. First, models of long-term contracting (e.g., Harris and Holmstrom 1982,

\footnotetext{
${ }^{9}$ Katz, Loveman, and Blanchflower (1995) and Katz and Autor (1999) suggest that demand shifts towards high-skilled labor may have hurt younger unskilled workers more than mature unskilled workers. The same may hold for changes in relative supply (Freeman 1975). A large theoretical literature has invoked the presence of implicit contracts for mature workers to explain the weak cyclicality of real wages for mature workers (e.g., Prendergast 1999, Malcolmson 1999). ${ }^{10}$ E.g., Clark and Summers (1981), Blanchflower and Oswald (1994), and Farber (2003) document the responsiveness of young workers' employment, wages, and job stability to cyclical shocks. We know that job movers have more procyclical wages than workers on the job (e.g., Devereux 2001, Bils 1985), and that job finding rates are more pro-cyclical than job separation rates (e.g., Shimer 2005b). Since labor market entrants are most likely to be among those searching for jobs (Topel and Ward 1992) and most likely to be unemployed (Clark and Summers 1981), this further underscores their vulnerability to cyclical shocks

${ }^{11}$ This could be modeled as temporary adjustment processes, as in a standard neo-classical model with flexible (but possibly slow) wage adjustment. It could also arise within a neo-classical model augmented with an explicit equilibrium relationship between wages and unemployment. A complete model of regional wage and employment adjustment with and without unemployment is outlined in Blanchard and Katz (1992).

${ }^{12}$ If workers pay for training by wage cuts (Mincer 1974) and jobs offer different degrees of learning (Rosen 1972), then earnings trajectories may also be affected by changes in the availability of jobs in the economy. However, if the amount of 'learning' jobs declines, then wage trajectory should be characterized by higher entry wages and lower growth rates. On the other hand, if workers forsake more earnings in recessions to have faster catch-up, we may underestimate initial earnings losses.
} 
MacLeod and Malcolmson 1993) have been used by Beaudry and DiNardo (1991) to explain persistent effects of labor market conditions when workers enter a firm. Second, models of job assignment (e.g., Prendergast 1993) can also imply persistent recession effects within firms. For example, Gibbons and Waldman (2004) rationalize persistent conditions found by Baker, Gibbs, and Holmstrom (1994) by the presence of task specific skills. Since workers should move employers to avoid persistent losses, firms-specific effects of recessions require some form of barrier to job mobility. This is more likely to occur in large firms that may provide rents, insurance, career-options, or other non-pecuniary benefits not captured in the wage, something we will analyze explicitly below.

Neither the standard approach nor the 'within firm' approach explicitly model job change. Yet, beneficial job mobility as predicted by models of search appears an integral part of young workers' careers (e.g., Topel and Ward 1992). For workers entering the labor market in a recession, search models predict that a temporary worsening of the wage offer distribution leads to a time intensive catch-up process. This process involves a high degree of job mobility with wage gains concentrated at job changes rather than accruing on the job (e.g., Burdett 1978). Given the prevalence of job mobility for young workers job search is likely to be an important channel of adjustment in the face of early unemployment shocks. However, although the job search model is featured in many empirical and theoretical analyses of the labor market, as of yet few papers analyze the causal determinants of job search, the role of search in the adjustment to labor market shocks, or the role of firm characteristics in the search process. ${ }^{13}$

The analysis of employer characteristics is important for understanding how workers advance in the labor market and respond to shocks. Recently, a number of studies suggest firms pay rents that cannot be explained by worker characteristics (e.g., Acemoglu 2001, Abowd, Kramarz, and Margolis 1999, Abowd, Creecy, and Kramarz 2003). Clearly, if high wage jobs are concentrated in firms that pay more on average, job search leads workers to switch towards high wage employers. Similarly, a longstanding hypothesis in labor economics suggests some firms and sectors pay rents, that high wage firms have more pro-cyclical job creation, and that young and less able workers are down ranked as employment at high wage firms and sectors contracts in recessions (e.g., Reynolds 1951, Reder 1955, Okun 1973, Cutler and Katz 1991, Hines et al. 2002). In this case, the initial loss from graduating in a recession occurs due to a reduction in employer quality, and the catch-up process involves transitions to better employers. ${ }^{14}$

\footnotetext{
${ }^{13}$ Since the seminal characterization of the job mobility process over workers' careers by Topel and Ward (1992), several authors have refined the notion and determinants of search. For example, McCall (1990) and Neal (1999) extend the definition of the search process to include occupations and industries and argue that some job switches have larger effects on future search than others. Yet, few papers estimate the determinants or differences in the pattern of job search, with the exception of the role of gender (e.g., Ureta and Light 1995, Keith and McWilliams 1999). Similarly, few papers analyze the role of firms. An exception are Topel and Ward (1992) themselves, who note that transitions to larger firms lead to more stable jobs and a related literature documenting correlation in turnover rates and firm size (e.g., Anderson and Meyer 1994)

${ }^{14}$ A process of cyclical upgrading can be motivated in a multi-sector model with queuing due to search frictions or some form of wage rigidity (McDonald and Solow 1985, Akerlof and Yellen 1985). Krause and Lubik (2005) formalize this
} 
Such a process of cyclical upgrading is supported by several stylized facts. First, industries pay wage premiums that cannot be easily rationalized by worker characteristics (e.g., Krueger and Summers 1988, Dickens and Katz 1988). Second, sectors paying higher wages have more pro-cyclical job creation, partly because of more volatile demand for their products (Okun 1973, McLaughlin and Bils 2001, Aaronson and Christopher 2004). Third, less able workers tend to flow to larger firms and high wage sectors in booms (Vroman 1977, Albaek and Sorensen 1998, Devereux 2002). Yet, to our knowledge few papers analyze the effect of labor market shocks on job transitions between different types of firms and industries (von Wachter and Bender 2006).

Standard career models do not predict differential effects of recessions on less advantaged workers; if wages are equal to workers' marginal product, similar shocks should lead to comparable losses. Only in the presence of rents do firms have incentives to select the most able workers for employment, and to reduce the employment of less able workers. In this case, labor market entrants are more affected than workers with greater labor market experience. Similarly, among labor market entrants, the least advantaged workers are likely to be most affected by cyclical conditions in the labor market. ${ }^{15}$

We know that low-skilled workers, non-whites, or women lose most in recessions in terms of wages (Hoynes 2000, Hines et al. 2002) and are most likely to drop out of the labor market (Bils 1985, Solon, Barsky, and Parker 1994). Yet, a high degree of heterogeneity in college quality or parental background suggests that even within the group of male college graduates those least advantaged may bear most of the burden of recessions. Large differences in the long-term cost of labor market shocks among prime earners would be a further indication that uniform measures may understate the true cost of business cycles (e.g., Lucas 1987, Barlevy 2005).

\section{Empirical Strategy and Data}

\subsection{Basic Earnings Model}

To measure the long-term effects on earnings of starting to work in a recession, our main specification exploits cyclical variation in unemployment rates for young workers at the regional level. Since

process in a general equilibrium framework with good and bad employers and on the job search. Alternatively, it could arise due to a process of sorting by comparative advantage (Gibbons, Katz, Lemieux, and Parent 2002, McLaughlin and Bils 2001). A process of cyclical up- and down-grading due to the adjustment of hiring and promotion standards was first described by Reynolds (1951) and Reder (1955), and taken up by Okun (1973, 1981), and Hall (1974). Barsky and Solon (1989), Solon, Whatley, and Stevens (1997), and Devereux and Hart (2005), among others, examine the importance of such a process within firms.

15 A cyclical process of adjustment in hiring and promotion standards has been often noted (e.g., Reder 1955). Barsky and Solon (1989) develop a numerical example. Generally, any model in which wages contain rents that vary inversely with worker ability predicts that high-wage firms should try to selectively hire more able workers, giving rise to the presence of queues. Such rents can arise due to rigid pay scales as in Hall (1974), or unions, as in Solow and MacDonald (1988). Lemieux (1998) describes the two-sided selection process for the case of unionized firms. While layoffs may be over-proportionately composed of less able workers in recessions if they accumulate less firm specific skills, as suggested by Neal (1998), this should affect low-skilled labor market entrants only indirectly via increased competition in the labor market. 
our main independent variable - the rate of unemployment - varies across province and over time, we collapse the individual level data at the level of graduation cohort, initial region of residence, and calendar year and work only with the cell means $\bar{y}_{c r t}$ of the log of annual earnings and other variables (weighted by the corresponding cell sizes). ${ }^{16}$ The cell level model on which most of the estimates in the paper are based on is

$$
\bar{y}_{c r t}=\alpha+\beta_{e} U R_{c r 0}+\phi_{t}+\theta_{r}+\gamma_{e}+\chi_{c}+u_{c r t}
$$

where $\theta_{r}, \chi_{c}, \gamma_{e}$, and $\phi_{t}$ represent unrestricted fixed effects for first region of residence (r), year of graduation (c), year of potential labor market experience (e), and calendar year $(\mathrm{t})$. The unemployment rate is measured at the time of graduation and the region of first residence $\left(U R_{c r 0}\right)$. The coefficients $\beta_{e}$ on the interaction of potential experience with the unemployment rate in the year of college graduation are the main effects of interest. To account for group specific error-components, we cluster standard errors at the cohortregion level.

Our data, further described below, allow us to observe almost the universe of male college graduates in Canada from the end of their first college degree every year for ten years into their careers. In our main specifications, we follow 20 cohorts entering from 1976 to 1995 in ten regions. Cohort effects control for permanent differences in earnings of different graduation years at the national level. ${ }^{17}$ Cohort dummies also eliminate earnings effects due to national time series variation in unemployment rates that is common across provinces. Province fixed effects ensure that we estimate effects of initial labor market conditions from changes in unemployment rates at the provincial level. Given the presence of unrestricted experience effects, the coefficients $\beta_{e}$ on the initial unemployment rates we estimate measure changes in experience profiles in earnings and other outcomes resulting from province-cohort-specific variation in unemployment rates.

We interpret the variation in UR to arise from changes in aggregate labor demand that are uncorrelated with characteristics of different graduation cohorts. Year-to-year variations in cyclical labor market conditions that identify our estimates move at a higher frequency than age-specific population,

\footnotetext{
${ }^{16}$ The only individual characteristics we could include are the actual duration of college and age. Instead of including years of college in an individual level model, we split the sample between workers who graduated and all workers with some college.

${ }_{17}$ That earnings may permanently differ across cohorts has been noted in previous research (e.g., Welch 1979, Card and Lemieux 2001). As it is well-known, cohort, potential experience, and year effects cannot be identified separately without an additional restriction on cohort effects is needed. Since we are mainly interested in experience effects and in their change over the business cycle, we simply drop one additional cohort effect from the regression. We could have chosen to restrict cohort effects to sum to zero (as suggested by Deaton 1997). This alternative does not alter our estimates of the experience profile. Of course, the resulting cohort effects differ. We also have assessed the linearity assumption implicit in Equation (1) by plotting and regressing the residuals of earnings and unemployment rates (from first stage regressions on province, year, and cohort dummies) by experience years. The results (shown in Appendix Figure 2) suggest that the linearity assumption is highly plausible.
} 
participation, or enrollment trends. ${ }^{18}$ To make sure we pick up mainly effects occurring due to demand conditions and avoid influences from cohort-specific labor supply changes of young workers, in our sensitivity analysis we have also used the unemployment rate for all workers as measure of initial labor market shock. ${ }^{19}$ Below and in the appendix we address other potential biases due to changes in cohort quality from selective graduation and selective employment. We also present a wide range of specification and robustness checks, such as different sample restrictions or different cohort restrictions.

At experience year zero our regression estimates the effects on earnings from current unemployment rates in region of residence plus region and year fixed effects. This specification is familiar from the wagecurve literature. ${ }^{20}$ By extending this basic model to allow for dynamic effects of the initial unemployment rate, we introduce the history of labor market shocks a worker has been exposed to as possible determinant of earnings. Since the wage-curve literature has shown that current unemployment rates affect workers of all ages, in some specifications we also allow the complete unemployment rate history since the start of the career to affect current wages.

On the one hand, this allows us to isolate the effect of labor market conditions at entry net of subsequent effects on earnings from exposure to a possibly prolonged recession or expansion. Among others, this distinguishes the role of labor market conditions at entry from the effect of labor market conditions when entering a new firm in mid-career (as stressed for example by Beaudry and DiNardo 1991). On the other hand, this allows us to directly compare the effect of aggregate unemployment rates at time of entry to the effect of unemployment rates for more mature workers. The result will help to assess the exceptional position of young labor market entrants and give us a benchmark to gauge the degree of persistence of early labor market shocks.

While our basic model can be easily extended to include persistent effects of unemployment rates in the region of residence at higher experience years, identifying persistent effects of market conditions at each experience level faces difficulties because of a lack of variation in regional unemployment rates in the data. Thus, we first consider including the current unemployment rate interacted with experience as an additional control. This extension assumes that only the unemployment rate at the time of labor market entry has dynamic effects on earnings.

To gauge the limitation this restriction places, we also experimented with a more complete dynamic model. Suppose we allow for dynamic effects of the aggregate unemployment rate a worker was exposed to at

\footnotetext{
${ }^{18}$ Despite increases in college enrollment rates in Canada since the 1980s, the correlation between unemployment rates for young and old workers is high and it has remained stable (Beaudry et al. 2000).

${ }^{19}$ Similarly, to assess the role of participation changes, we also replicated our results using the employment-populationratio for 15 to 24 year olds.

${ }^{20}$ However, unlike the wage-curve literature, the main focus of our paper is to estimate the long-term effects on earnings of temporary unemployment rate shocks rather than uncovering an equilibrium relationship between wage levels and unemployment rates.
} 
each in experience year (e) in the relevant region $\left(r_{e}\right)$, denoted by $U R_{r_{e} e}$ (note that this unemployment rate will differ for different graduation cohorts). Denote the effect on earnings in experience year e from the unemployment rate at experience year $0(1,2,3,4, \ldots)$ by $\beta_{e, 0}\left(\beta_{e, 1}, \beta_{e, 2}, \beta_{e, 3}, \ldots\right)$. Dropping other regressors and the region subscripts on the unemployment rates for simplicity, the complete dynamic model can be written succinctly as

$$
\bar{y}_{c r t}=\phi_{t}+\theta_{r}+\chi_{c}+\gamma_{e}+\beta_{e, 0} U R_{c r 0}+\beta_{e, 1} U R_{r_{1} 1}+\beta_{e, 2} U R_{r_{2} 2}+\ldots+\beta_{e, 10} U R_{r_{10} 10}+\varepsilon_{c r t},(2)
$$

where we impose the restriction $\beta_{e, s}=0 \forall s<e$. The full dynamic regression estimates the effect of the transitory component of each aggregate unemployment condition, net of its correlation with other unemployment rates affecting the worker in adjacent experience years.

This more complex model allows us to interpret the coefficient of basic regression model that omits control variables for subsequent unemployment rates after labor market entry. Without dynamic UR controls, our basic estimate of the effect of the first unemployment rate exposure captures the average change in earnings from graduating in a recession given the regular evolution of the regional unemployment rate faced afterwards. In other words, it estimates the dynamic effect of the first unemployment rate plus the weighted sum of the effect of unemployment rates a worker faces in his career. ${ }^{21}$

Due to high inter-temporal correlation of aggregate unemployment rates, it is difficult to estimate the fully unrestricted model in Equation (2). However, it turns out that more parsimonious models can yield the desired results. For example, the time series process of unemployment is often characterized as an AR(2) with high persistence of the first lag. ${ }^{22}$ We estimate the full dynamic model including unemployment rates at all periods fully interacted with experience dummies, as well as a more restricted model with only two additional unemployment rates. As expected, these models give similar results.

In contrast to the basic estimate from Equation (1), the estimates of these dynamic models capture the effect of the very first exposure to unemployment rates, net of the effects of persistent local labor market conditions. Interestingly, the effect of the early unemployment rate turns out to be remarkably stable in all specifications we try. We would also like to use the full model in Equation (2) to compare the dynamic effect of unemployment rates at labor market entry with dynamic effects of unemployment rates once a worker has

${ }^{21}$ The omitted variable bias of the coefficients on the first unemployment rates is

$$
p \lim \hat{\beta}_{e, 0}=\beta_{e, 0}+\sum_{d=1}^{e} \beta_{e-d, d} \frac{\operatorname{cov}\left(U R_{r c 0}, U R_{r_{d} d}\right)}{\operatorname{var}\left(U R_{r c}\right)} .
$$

${ }^{22}$ In this case, the first two leads of unemployment (i.e., unemployment at experience years one and two) should remove omitted variable bias from the dynamic effect of the unemployment rate at experience zero. Some prefer to model it as ARIMA(1,1,0), but often a prior of stationarity is invoked to distinguish a persistent $A R(2)$ from the similar nonstationary process (e.g., Blanchard and Katz 1992). 
entered the labor market. However, it is difficult to separately identify dynamic effects of unemployment rates at adjacent experience years given the high persistence of unemployment innovations. We therefore also consider a restricted model in which we constrain the effects of unemployment to be the same in groups of experience years. This model is further discussed in the Appendix. ${ }^{23}$

As suggested above, our identification strategy allows us to obtain an estimate of the effect of early labor market conditions if there are no unobserved characteristics correlated with the initial unemployment rate that vary with experience. This may fail if early labor market conditions affect workers' labor supply decisions (e.g., see Bils 1985, Solon, Barsky, and Parker 1994). The labor force exit of less able workers would lead to an understatement of any negative effect of unemployment rates on earnings, and our estimates would represent a lower bound (however, if worse workers reenter the labor market with a time lag, it would lead us to over-estimate persistence). As we show below, initial unemployment rates have small effects on the propensity to temporarily exit our earnings sample due to unemployment or non-employment. To further address the problem of selective labor force participation, the large sample sizes allow us to re-estimate our main models using a sample of workers with positive earnings in each period. ${ }^{24}$ In addition, to focus on a sample of men with stable labor force attachment, we drop those who permanently stop filing taxes at any point in time. Since this group may contain workers who emigrate (mainly to the U.S.) for economic reasons, we compare our main results including those who permanently stop filing in the sensitivity analysis.

Individual characteristics might also correlate with unemployment rates at college exit if more able students remain in college longer to avoid graduating in a recession. If better student delay, that would lead us to overestimate the initial negative effect and underestimate the degree of persistence. This is unlikely to explain an important part of our estimates of persistent effects because the process of reversion of initial losses takes too long to be explained by lagged entry of more able workers. Two additional results lead us to believe the bias from selective entry is small. First, a detailed analysis of college duration in response to unemployment rates at actual and predicted time of graduation indeed suggests there are only small increases in the duration of college in response to unemployment rates for our preferred sample. Second, to also address the problem directly, we use information on the date of entry into college and official degree duration to construct predicted graduation dates for all graduates in our sample. We then use the unemployment rate in the predicted year of graduation as an alternative source of variation to identify the long-term effect of initial labor market conditions. In the appendix, we discuss two sets of estimates based on this additional measure.

\footnotetext{
${ }^{23}$ Instead of imposing restriction across experience years, we have also experimented with more parametric models of the decay of the initial effect of unemployment. While an exponential rate of decay is rejected by the data, the dynamic behavior of unemployment rate effects could be capture reasonably well by a fourth order polynomial in the time of the shock. However, this approach doesn't solve the problems inherent in the data - too persistent unemployment shocks and too few cohorts at older ages.

24 This is generally not possible in the smaller survey data sets used to assess this kind of bias (e.g., Bils 1985). To further check for selective participation decisions, we also analyzed changes in predicted earnings with experience and with early unemployment shocks. While there is a very small but significantly negative gradient in predicted earnings with experience, perhaps suggesting a pattern of migration, there is basically no correlation with early unemployment shocks.
} 
First, we show reduced form estimates using the unemployment at predicted graduation as the relevant labor market shock. The second set of estimates present instrumental variable estimates using the unemployment rate at the predicted date of graduation as an instrument of the unemployment rate at actual graduation. Since the case can be made for either approach, we present both. ${ }^{25}$

\subsection{Analysis of the Channels of Catch-Up}

Since initial labor market conditions will affect earnings through multiple channels, the estimated coefficients in the regression of log earnings represent reduced form effects of the initial unemployment rate on earnings-experience profiles. We cannot identify the effect of the separate channels because each is in itself affected by choices made by the worker and by his possibly unobservable characteristics. Instead, we provide an assessment of their importance by directly analyzing the impact of the unemployment rate on the channels themselves. We examine three sets of variables: first, outcomes related to employment such as receipt of unemployment insurance, filing income taxes with zero earnings, and not filing taxes. Second, outcomes relating to job mobility, such as changes in workers' main employers, changes in industry of main employer (at the one, two, and three digit level), mobility across provinces, and whether workers left their first employer or their first industry. Third, we analyze the effect of graduating in a recession on the characteristics of young workers' employers, further described below.

An important step in attributing job mobility to a productive search process is to analyze whether it is voluntary and beneficial. To obtain a first insight into this question, we first follow Topel and Ward (1992) and characterize the average association of job and industry mobility with wage growth. Topel and Ward (1992) established that about 30-50\% of initial quarterly earnings growth occurs at job changes, and we confirm similar results for annual earnings in Canada. ${ }^{26}$ We then estimate simple descriptive models of wage growth as a function of initial unemployment rates where initial unemployment rate is interacted with mover status, i.e.,

$$
\Delta \log (\text { earnings })_{i c r t}=\alpha+\phi_{t}+\theta_{r}+\chi_{c}+\gamma_{e}+\beta_{e} U R_{c r 0}+\lambda M o v e_{i c r t}+\delta M o v e_{i c r t} U R_{c r 0}+u_{i c r t},(3)
$$

where $\delta$ is the difference in the effect of initial unemployment rates on earnings growth by different mover status (indexed by the Move-dummy). While these parameter estimates clearly have no causal interpretation, they capture the importance of job change in the dynamic pattern of unemployment rate effects by showing whether the correlation of job change and job mobility increases for workers experiencing adverse initial conditions.

\footnotetext{
${ }^{25}$ Note that if the graduation date is endogenous, so are potential labor market experience and initial cohort effects. We have estimated a series of reduced form models with predicted cohort effects and predicted experience with little change in the main results.

${ }^{26}$ This is a stable pattern across countries (Giuliano and von Wachter (2004) report very similar numbers for France and Germany).
} 
To directly assess the benefits of job mobility and to gauge the potential importance of firm heterogeneity, we also characterize the effect of early unemployment rates on the quality of young workers' employers. We construct measures of average characteristics of each employer controlling for year effects, and merge these to the individual level data using workers' employer identification numbers reported on tax returns. In this way, we construct average log median earnings, average total payroll, and average number of employees at the firm level, averaged over the entire period of existence of the firm for all employees (not only workers with college education) controlling for aggregate year and region effects. If more able workers are sorted into better firms, the wage measures do not necessarily capture the fixed firm component in pay rates, but a more inclusive measure of 'firm quality'. Results by Abowd et al. (2003) suggest that this correlation may be weak. We use multiple measures of firm quality in case some measures include workers more selectively than others.

If workers simply search for better firms, then a large fraction of initial wage losses should fade when we compare workers starting at the same firm in different cyclical conditions. To gauge the role of heterogeneity in firms' payment structures in initial wage losses and their reversion, we examine how our baseline results change after including fixed effects for initial firm and initial industry. Clearly, these estimates are affected by potential change in the degree of selectivity into firms across the business cycle. If, as suggested at the outset, more able workers are down-ranked to lower wage firms in recessions, we may underestimate the degree of within firm wage changes. ${ }^{27}$

Last, to further analyze the role of the first employer, to see whether high-wage firms have more procyclical wages, and to relate our main results to papers analyzing careers within firms, we also separately estimated the dynamic effects of initial unemployment rates by average wage or size of the initial employer. If careers evolve within firms, then changes in contracting, job assignment, or training over the business cycle might lead workers starting at large firms to have smaller but possibly more persistent wage declines than workers starting in small firms. ${ }^{28}$

Another potential channel of how workers regain their lost earnings is mobility across provinces (Waggoner 2004). However, the descriptive analysis shows that regional mobility is much lower in Canada than the U.S. To assess directly whether reversion occurs by moves to economically vibrant provinces, we included the history of aggregate unemployment rates and fixed effects for current province of residence interacted with year effects as explained above. To check whether provincial mobility is beneficial for other

\footnotetext{
${ }^{27}$ To allow for firm specific experience profiles, we also include an interaction of initial firm fixed effects and experience effects, effectively allowing for firm specific experience profiles. Since young workers' earnings may not be entirely a function of their ability (due for example to the presence of employer learning), including worker fixed effects or working with changes in earnings is not an ideal strategy to deal with this problem.

${ }^{28}$ Again, the probability of starting to work at a 'high quality' employer may be correlated with workers' ability, and the degree of selectivity might be affected by early unemployment rates. To address this problem, we have included control functions in the fraction of workers starting to work at 'high quality' firms. Similarly, we have included average fathers' income as control function. Neither affects our results, and is available upon request.
} 
reasons (for example due to the wider scope for good job matches), we have also analyzed the incidence and returns to provincial mobility directly as an outcome and found them to be small. In addition, variation at the national level represents shocks affecting the entire labor market whose effect is unmitigated by inter-regional mobility. Thus, we also present estimates based on variation of unemployment rates at the national level. ${ }^{29}$

\subsection{The Heterogeneous Cost of Recessions}

Even among college graduates there may be important heterogeneity in earnings capacity due to variation in college quality or choice of major. Yet, if wages are equal to marginal products, more or less advantaged labor market entrants should not suffer different consequences from early recessions unless they face different demand shocks. To assess the importance of heterogeneity we use the college of graduation, the major, and the years of schooling to predict future earnings for each individual and reanalyze our data by quintiles and deciles of predicted earnings. Since these estimates are based on differences in average realized earnings of workers in different colleges and majors, they reflect the effect of college quality as well as the fact that more able workers may attend certain universities. Thus, we can compare the initial losses and reversion process suffered by workers with different initial earnings capacities. In addition, these estimates deliver an additional dimension of variation in the channels of recovery and the decline in earnings losses that will be helpful in assessing the underlying economic mechanisms driving the catch-up pattern.

To characterize the overall cost due to cyclical fluctuations sustained by different groups in the population, we can use our estimates to approximate the present discounted loss of annual earnings arising from actual early recession shocks. This complements existing estimates of the costs of recessions based on the average standard deviation of consumption or earnings process. Most of these estimates are based on Lucas' (1987) original exercise of comparing the present discounted value of utility derived from two consumption streams, one uncertain and one certain. Lucas asked by what proportion consumption has to rise to make workers indifferent between the two paths. ${ }^{30}$ Lucas' initial findings of extremely small valuations

${ }^{29}$ The national model we estimate is

$$
\log \bar{w}_{c t}=\alpha+\phi_{t}+\gamma_{e}+\beta_{e} U_{c 0}+\chi_{0} c+\chi_{1} c^{2}+u_{c t}
$$

where the dependent variable is real earnings, and $\phi_{t}$ and $\gamma_{e}$ represent calendar year and potential labor market experience effects, respectively. The national model includes either linear or quadratic cohort trends, since unrestricted cohort effects are not identified.

${ }^{30}$ Specifically, Lucas compares the present discounted value (PDV) of utility from two consumption streams; one certain, $\left\{C_{1}^{*}, C_{2}^{*}, \ldots\right\}$, and one uncertain $\left\{C_{1}, C_{2}, \ldots\right\}$, where $C_{t}=\left(1+\varepsilon_{t}\right) C_{t}^{*}$, and epsilon is a white noise shock with constant variance. He then asks by proportion $\mu$ the uncertain stream has to be higher in each period than the certain stream to be of equal PDV utility. Using a constant relative risk aversion (CRRA) utility function with coefficient of relative risk aversion equal to one and estimates of the standard deviation of aggregate consumption, he derives that for the average worker $\mu$ is extremely small. More generally, Lucas' calculations suggest that costs of recessions are very small unless risk aversion is extremely high. Lucas' original study has been extended to take into account different form 
of uncertainty have been revised in the literature in favor of more nuanced estimates taking into account imperfect capital markets, lack of savings, or concentrated job losses (e.g., Barlevy 2005). We replicate the classic Lucas measure for different groups in the population using the actual changes in the streams of annual earnings we estimate. Since none of these estimates use actual changes in earnings or consumption in response to a recession shock to estimate the cost of recessions or explores the role of heterogeneity in the costs of recessions, our estimates provide a useful complement to the existing literature.

\subsection{Canadian Administrative Data and the Evolution of Careers}

Our results are based on a unique match between three large administrative data sets collected and compiled within Statistics Canada that is described in detail in the Data Appendix. The data combines administrative information on about $70 \%$ of Canadian college students and college graduates from 1976 to 1995 with longitudinal individual income tax records and firms' payroll information covering the years from 1982 to 1999.31 The data contains detailed information about individual students' course of study (such as type of degree, major, date of graduation), with detailed career information (e.g., annual earnings, province of residence, receipt of unemployment benefits) and information on employers. Exploiting the panel nature of our firm data, we calculate average firm size, average median wage, and total payroll taken at the establishment level, with year fixed effects taken out. All firm characteristics refer to permanent attributes so that they remain unchanged across the worker panel (i.e., an individual's firm characteristics can change only if she moves employers).

To generate a uniform sample with a common definition of labor market entry, we focus on the effect of recessions at the end of the first exit from college and exclude workers obtaining higher degrees from our sample. ${ }^{32}$ As shown in Appendix Table 1 even within this relatively homogeneous sample there is a high rate of drop out and high variance in college attendance. Despite the use of administrative data there is likely to still be some measurement error in actual graduation in our data. Thus, our main sample excludes college dropouts to focus on a more homogenous group of workers with better measured graduation date. To do so, we calculate the difference (D) between actual and predicted graduation year, and keep only workers with

\footnotetext{
of risk aversion, absence of savings, or unevenly distributed income shocks. To our knowledge, no one has used the effects of actual recessions shocks or considered heterogeneity in workers' underlying earnings capacity.

31 The word 'college' is somewhat a misnomer in Canada because it is used usually to refer to one or two year community-level post-secondary institutions rather than degree-granting universities. In keeping with the terminology most often used, we shall refer to Canadian universities as colleges.

32 Since we find early recessions do not affect the probability of obtaining a graduate degree, this does not affect our results. We have experimented with other definitions of the relevant date of labor market entry (such as last degree or last degree of continuous education), with little effect on the results. In the sensitivity analysis, we also show results using a sample that includes workers obtaining a post-graduate degree.
} 
non-negative difference. The right columns of Appendix Table 1 show characteristics for that sample. Among the sample of workers on or above grade $89 \%$ graduate, and average duration of college is about 4 years. ${ }^{33}$

To assign the unemployment rate at the time of graduation, we have to choose a relevant province of residence. We settled for the province of first residence as the relevant labor market for young college graduates. ${ }^{34}$ We impose some additional basic sample restrictions and limit the degree of missing observations on earnings. In particular, we drop workers who permanently stop filing taxes with the purpose of removing individuals who stopped being recorded annually because they left the country, obtained a new personal identification number, entered the underground economy, or their file was simply miscoded along the way. Further sample restrictions are discussed in the Data Appendix.

Figure 1 and Appendix Table 3 describe the general experience profiles and mobility patters in our data, and also document the many similarities between experience profiles in Canada to those in the US. To summarize briefly, the first years of the careers of young male Canadian college graduates are characterized by steep wage growth (also documented for the U.S. by Mincer 1974, and Murphy and Welch 1990), frequent job changes (Topel and Ward 1992, Giuliano and von Wachter 2004), initially unstable labor force attachment (Ryan 2001, Gardecki and Neumark 1998), some interregional mobility (Waggoner 2004), and frequent industry changes (McCall 1990, Neal 1995, Parent 2000). In addition, we document a strong experience gradient in average size and average wages paid by employers - from year one to ten, average firm size and average firm wage increase by $34 \%$ and $24 \%$, respectively (Appendix Table 3). Male Canadian graduates tend to move to firms that on average pay more and are larger the longer they progress through the labor market. ${ }^{35}$

The time series of unemployment rates at the provincial level and the provincial average are shown in Panel A of Figure 2. Canada experienced two major recessions in the early 1980s and 1990s that increased young workers' unemployment rates for certain years by more than seven percentage points. This will work for our national specification. ${ }^{36}$ Figure $2 \mathrm{~A}$ also displays a high degree of regional heterogeneity. During this

\footnotetext{
${ }^{33}$ By restricting our main discussion to graduates, we are also sure of picking up the effect of early unemployment rather than the drop out decision. Our data suggests undergraduates are unlikely to finish early or drop out because of labor market conditions. Not surprisingly, the most of the results hardly differ when replicated with the full sample.

${ }^{34}$ The alternative, province of college, gives similar results. Appendix Figure 1 compares the effect of the two choices for our main estimates. With choice of province of college as the relevant labor market, the unemployment rate at experience year zero fails to pick up some effects of the unemployment rate at experience year one that are absorbed if we choose province of first residence as relevant market. This leads us to believe that province of first college has a stronger measurement error than province of first residence. If we group 0-1 together, the results of the two choices are indistinguishable. An examination of the incidence and gains of province mobility below leads us to believe that selective mobility from province of college to province of first residence is small.

${ }^{35}$ Using data from the Current Population Survey Appendix Table 5 shows that a similar pattern is also present in the U.S. (see also Figure 1).

36 The picture shows unemployment rates for 15 to 24 year olds. Using unemployment rates defined for workers age 20 to 24 or for college graduates only does not substantially alter the pattern of unemployment over time or across regions, nor does it affect our results.
} 
period, an increase of unemployment rates of 5 percentage points (or about two standard deviations, see Appendix Table 1) describes a typical large recession. ${ }^{37}$

A potential concern is whether the variation in youth unemployment rates in Figure $2 \mathrm{~A}$ represents changes in demand conditions facing male college graduates. Although education-specific unemployment rates are too noisy for most provinces, the unemployment rate for young college educated men for the larger states, such as Ontario or Quebec, are closely correlated with the youth unemployment rate and the average unemployment rate. As noted above unemployment rates between older and younger workers in Canada move in parallel at different levels. This appears to hold for college graduates as well.

\section{The Persistent Effect of Initial Labor Market Conditions on Earnings}

Panel B of Figure 2 shows average earnings-experience profiles of the graduation cohorts in our data at the national level together with their entry wage at experience one (their first full year of work) and the average wage for 'mature' workers (workers with 5 to 10 years of experience). ${ }^{38}$ One can clearly see differences in starting wages across graduation cohorts leading to differences in average cohort earnings. Thus, as found by others, if we were to add cohort effects in a simple earnings recession, they significantly improve the fit of the model. However, the figure also shows a clear pattern of convergence. That is, initial differences in starting conditions appear to fade over time. Cohort effects appear to have a time-varying component, or, as noted by Beaudry and Green (2001), experience profiles vary across cohorts.

There exists a strong correlation between starting wages and initial unemployment rate conditions, which persists into higher experience years and slowly fades over time. This is shown in Panel A of Figure 3, which graphs national unemployment rates for young workers with wages at different years of experience by graduation cohort (both expressed as deviations from their means across cohorts). The correlations in Panel A strongly suggest that part of the initial but fading earnings differences in Figure 2B are driven by variation in initial labor market conditions. In addition, the Panel B in Figure 3 compares the effect of aggregate unemployment on wages for workers with different labor market experience - the figure clearly shows how college graduates just entering the labor market bear most of the burden of recession adjustment, something we will return to below.

The correlation at the national level is exploited in Table 1, which shows the long-term effect of national unemployment rates on log real earnings, controlling for year and experience effects and linear or quadratic cohort trends. Column (1) and (4) show the shift in experience profiles due to an unemployment

\footnotetext{
${ }^{37}$ Panel B of Appendix Table 1 shows summary statistics. Appendix Table 1, Panel C also shows the distribution of our sample between provinces and the mean and standard deviation of unemployment across Canadian provinces. The sample of students differs across provinces because of population differences and college representation. We address this by including initial province fixed effects (and sometimes also current province fixed effects).

38 Graduation cohorts 1976 and 1994 have lower and higher average earnings then the rest of the sample, respectively, due to variation in college reporting rates (Appendix Table $2 \mathrm{~A}$ shows the respective decline and increase in sample sizes). In the regression models, this is accounted for by cohort fixed effects; in the figures these two cohorts are dropped.
} 
shock in experience year zero including a linear cohort trend for all workers with some college and those in the graduate sample, respectively. Standard errors are clustered at the level of graduation cohort to allow for group level error terms. The results suggest a strong initial effect that persists but fades after about five years in the labor market.

\subsection{Main Regional Models}

Our main results are drawn from regional models that include cohort effects as well as effects for initial province of residence as described in Section 2. The shifts in experience profiles due to an initial provincial unemployment shock are shown in Column 3 of Table 1 for all workers with at least some college and Column 6 for the graduate sample. The initial effects are similar in size to those from the national model, but starting at experience year four, the regional estimates remain more persistent, and converge to zero only after 10 experience years. Although estimates for the graduates are slightly more precise, there is little difference in the point estimates for graduates and all workers. This is apparent in Figure 3A, that plots the main coefficient estimates against potential experience. It does not appear that those with a college degree fare better than the full sample.

Comparing national results with the regional results, we can exclude a strong correlation of initial unemployment rates at the national level with changing unobserved cohort characteristics. Similarly, as shown below, it does not appear that the regional results are driven by more persistent unemployment shocks. However, national estimates may be more strongly affected by measurement error problems due to misassignment of the relevant initial labor market shock. Inter-regional mobility is less common in Canada than in the U.S. Thus, the relevant labor market shock is at the regional level, an effect only partially absorbed by the national unemployment rate. Lower regional mobility (and, as we will see below, lower gains to mobility) also explains why results from the national model are not larger than the regional model.

Due to the presence of continuing exposure to adverse labor market conditions, these estimates represent a summary of the earnings losses the average worker can expect due to entry in a depressed labor market. With an increase in unemployment of 5 percentage points -- roughly a shift from boom to recession - annual wages are about 9 percent lower in the first year after college, still 4 percent lower after 5 years out, and about 2 percent lower 9 years out. Overall, we view the regional and national results as telling a consistent story. Graduating during a recession leads to significantly lower earnings at the beginning of an individual's labor market, but the gap converges to zero within six to eight years after graduation. These results are consistent with estimates from the wage curve literature. ${ }^{39}$ Similarly, they are consistent with

\footnotetext{
39 The results are also consistent with previous evidence on the impact of unemployment on wages in Canada. Blanchflower and Oswald (1994) obtain a coefficient for log annual earnings on province unemployment controlling for region and year fixed effects for a representative sample of Canadian workers of -.013 (Table 8.3). This is very similar to what we find for male college graduates, despite the fact that their regression models include a range of individual characteristics. They also report an elasticity of -.065 for workers with university degrees and -.169 for workers less than age 25 (Table 8.4). If we divide our estimated coefficients by the average unemployment rate (14\%), we obtain an
} 
estimates by Bloom and Freeman (1988) who find that initial effects due to differences in cohort sizes fade after ten years. Similarly, Devereux (2003) finds among a sample of workers from all ages that half of a wageshock, instrumented by local unemployment conditions, is still present after about five years. Kahn's (2005) finds somewhat more persistent losses than ours, perhaps due to her focus on graduates entering the strong recession of the early 1980s. ${ }^{40}$

The entry into a depressed labor market appears to leave persistent but temporary scars. These results (Figure 4A, Table 1) are robust to a variety of sensitivity checks. First, our results do not seem to be driven by any particular measure of labor market conditions. To counter the concern that the unemployment rate for young workers may be affected by cohort characteristics, we replicated our results with the unemployment rate for all workers (Appendix Figure 1, Panel A). We also find similar results from using the employment population rates for workers age 15 to 25 (or men only). Second, we compare the effect of average unemployment rates in experience year zero, 0 to 1, 0 to 2, and 0 to 3 (Appendix Figure 1, Panel B). ${ }^{41}$ While high average unemployment in the early years tends to make the effects more persistent, it does not appear that the effects captured in the main models are driven by periods of extended unemployment. As confirmed by the results in Section 4.3., the driving force behind our main results is the shock in the very first years after entry into the labor market.

We have tried various other sample and specification choices, none of which substantially affected our results. Including college students who enter the labor market after a graduate degree has no effects on our results (Appendix Figure 3) suggesting workers do not selectively enter advanced degree programs due to unemployment. We also tried various ways of excluding workers with repeatedly missing wages, and find little effect on our results. ${ }^{42}$ We have re-estimated all of our results using the province of college as the region for

elasticity of -.11 to -.13 for our younger sample of graduates. The corresponding results for the U.S. are an elasticity of .102 for all workers, -.064 for workers with at least 13 years of schooling, and -.192 for workers age 25 or less.

${ }^{40}$ The size of the initial loss and the degree of persistence depends on the strength of the initial unemployment rate, as well as on the life-time exposure of a cohort to unemployment. Since due to the cyclical nature of unemployment, lifetime unemployment exposure is partially determined by the timing of entry, the fortunes of cohorts may differ. Below we try to control for some of these differences directly. To assess whether the average profiles are driven by single 'unlucky' cohorts, Panel D of Figure 5 shows the same estimate for several cohort groups. While some differences across cohorts are apparent in the size of the initial shock and the speed of reversion and a subset of cohorts graduating in the early 1980s appears to experience more persistent effects, overall the patterns of initial loss and reversion are very similar across cohorts.

${ }^{41}$ Since unemployment history is available only for cohorts entering after 1981, these show more persistent effects than the full set of cohorts used in Table 1. We also used the unemployment rate for young men instead of that for all young workers, again with no difference in results. Unfortunately, alternative measures based on young college graduates only proved to be too noisy in several of the smaller provinces and led to attenuated results. For the larger provinces, our results were confirmed even for this very narrow measure.

42 Appendix Figure 3 shows the results with those who permanently stop filing included. We also used the sample of workers with a valid match to their father's income to assess the degree of selective exclusion due to non-filing. Although having a valid match to father's earnings is affected by initial unemployment, perhaps through an effect on regional mobility, if we replicate Table 1 using only those with a valid match the results are very similar as for all workers. We conclude that workers with a valid father's income match are similar to the entire sample. We then regressed average father's lifetime income and "stopped filing", with insignificant and small slopes. 
the relevant initial shock with no basic change in our results. ${ }^{43}$ Part of the reason why national results show more persistent effects of initial labor market conditions on wages might be that workers are 'stuck' in persistently slack regional labor markets. To address this possibility, we also included current province by current year fixed effects (shown in Appendix Figure 1, Panel C), which barely show any differences in the results. This is also a first indicator that mobility towards provinces with higher wages is not a strong source of catch-up in our sample.

To isolate the effect of a short-term initial exposure to adverse labor market conditions, the large samples and ample cohort variation at our disposition allow us to control for the confounding effects of regional unemployment persistence. This is done in the first column of Table 2, which adds an interaction between unemployment rate in current state of residence and experience, as well as fixed effects for current state of residence. ${ }^{44}$ As predicted, the initial effect is reduced by persistence of labor market conditions, but the difference is small. Results by Beaudry and DiNardo (1991) suggest that ensuing labor market conditions may have persistent effects themselves for workers not changing employers. Similarly, job search predicts that unemployment conditions at the beginning of employment spells persist for job changers. As shown in the remaining columns of Table 2, and discussed in more detail in the sensitivity analysis in the appendix, the basic results are essentially unaffected if we allow for persistent effects of other labor market conditions as well. The results of the grouped model discussed in Section 3 and the Appendix are displayed graphically in Figure 5 (Panel A). A part of the effect of initial unemployment rates is due to persistent effects of continuing labor market conditions, but the bulk is driven by the very first shock alone.

Figure 5 (Panel B) also summarizes another important step of the sensitivity analysis, the question of selective college graduation, which is discussed in detail in the Appendix. Summarizing, since most of our measures indicate insignificant effects of unemployment rates on college duration, selective timing of graduation does not appear to be an important phenomenon in our data. Not surprisingly, when we use the unemployment rate at predicted graduation as instrument our estimates confirm the main ordinary least squares results. Although all our results go through with the instrumental variable estimate, in what follows we report the more efficient ordinary least squares estimates.

\subsection{Effects on Employment and Participation}

If unemployment rates affect participation, we might be concerned that our wage-estimates of the previous sections are estimated from a selected sample. Moreover, under a human capital model, individuals

\footnotetext{
43 As shown in Appendix Figure 1, Panel C the results for earnings are marginally weaker initially but as persistent. This is likely due to measurement error, since in this case the shock in the province of residence at experience year one has very strong effects. If we group experience years zero and one together, the effects are very similar. While there may be a concern about selective mobility based on the unemployment shock in the province of college, we feel the effect of measurement error due to the mis-assignment of initial province is larger. This is supported by relatively low incidence and gains from regional mobility.

${ }^{44}$ Note that since we only observe full history of province of residence for cohorts graduating 1982 onward, Table 2 uses only these cohorts. As further discussed in the sensitivity analysis, the effects for all cohorts are comparable.
} 
not working lose time during which they acquire skills and knowledge that make them more productive. Thus, if entering the labor market in a recession reduces time worked, this might be a channel through which earnings are affected even in the medium run. Table 3 replicates the same results as in Table 1 using the fraction of workers claiming unemployment insurance benefits, the fraction of workers filing taxes with zero earnings, and the fraction of workers not filing taxes in a given year. The table shows an initially significant increase in fraction zero earnings and the fraction of unemployment insurance (UI) claimants that fades within three experience years. ${ }^{45}$ The effects are numerically small and can be completely explained by shortterm persistence of local unemployment rates (not shown). A temporary unemployment rate shock has no persistent effects on employment or participation of male college graduates. ${ }^{46}$

To gauge the magnitude of these numbers, add the fraction workers reporting zero earnings and the fraction UI claimants for the group on or above grade. In the first year in the labor market, a five percentage point increase in unemployment would induce an increase in this measure of 'time not spent working' of about 1 percentage point. If the typical length of a spell of non-employment were 6 months, then the expected amount of time lost would be about 2 days or 0.06 months ( 0.01 times 3$)$. These back of the envelope calculations suggest that the loss of experience due to labor market entry in recessions is not very large for the average college graduate. These results are echoed by Kahn (2005), who finds small initial effects on hours, employment, and weeks worked for male college graduates in the U.S. after the 1982 recession.

Since our sample does not contain information on time worked, we also replicated our results with the Canadian Census (available in a Web Appendix). ${ }^{47}$ Decomposing the effect of early unemployment rates on annual earnings into the effect on weeks worked and on weekly wages we find that the effect on weeks worked is short lived. The majority of the persistent effects we find is driven by a reduction in weekly earnings. Consistent with the small effects on employment we find our results change little if we restrict our sample to workers with positive earnings in each year (see Figure 5, Panel C). Thus, neither changes in labor market experience nor selective entry or exit from the earnings sample of workers of different abilities affect the main pattern of reversion we see. ${ }^{48}$

\footnotetext{
45 The fraction of missing earnings (those not filing) rises only in the year of college exit, during which most graduates only work part of the time.

46 The effects are very similar for the sample of all workers. Table 3 also displays a pattern of 'overshooting' after experience year 7 some measures that would imply workers who had initially higher instability become more stable later relative to their more lucky counterparts. One could think of various hypothetical explanations of such a phenomenon. However, the estimates are numerically very small and never above 0.2 percentage points.

${ }^{47}$ Similarly, although male college graduates are indeed a group of workers with very high labor force attachment, the cross-sectional experience gradient of weeks worked from Census data reveals that in the first three to four years of there is still some heterogeneity in work patterns that stabilizes afterwards. To further examine the importance of a loss in time worked, we replicated our results using four years from the Census $(1981,1986,1991$, and 1996) and decomposed the main effect on annual earnings into effects on weekly earnings and weeks worked. Although due to the different nature of the data we have to make some assumptions on the timing and province of college graduation, the main effects are very similar to our results.

${ }^{48}$ This is corroborated by the fact that those who permanently stop filing do not appear to be any different from those who remain active (Panel A of Appendix Figure 3). The estimates based on the balanced panel in Figure 5 (Panel C) are
} 


\subsection{Mobility across Firms, Industries, and Regions}

Job search is a common explanation for both high wage growth and high job mobility in young workers' careers (e.g., Topel and Ward 1992). Several studies aim at testing the basic elements of job search theory, such as the effect of past wages, tenure, and experience on the probability of job change (e.g., Topel and Ward 1992, Manning 2002, Farber 1994). While most of these studies try to control for unobserved heterogeneity, few exploit external sources of variation to identify the effects of interest. In this section we estimate the direct effect of early labor market conditions on the annual propensity of job change.

Figure 4 (Panel B) graphs the effects of initial unemployment rates on the probability of changing employers. Initially, a 5 percentage point increase in regional unemployment rate raises the rate of job change by about 1.5 percentage points (depending on the sample); the effect gradually declines with experience until it is not significantly different from the baseline in experience year 8 to 9 . Table 4 shows the coefficient estimates of the effect of unemployment rates at time of college exit for various measures of job mobility during the first ten experience years for the regional model estimated for the graduate sample (the results for all workers are very similar and available on our website). The increase in mobility is significantly larger but shorter lived at the national level. ${ }^{49}$ Overall, the results in Table 4 yield a persistent increase in mobility relative to the baseline of about 4-5\% (see Appendix Table 3A).

To gauge the magnitude of these effects, consider the reductions in job change with labor market experience apparent in Figure 1. Between experience years 2 and 4, the rate of job change for graduates declines by 3 percentage points annually. If this increasing stability reflects improving job matches due to search, a 2 percentage point increase in job mobility is comparable to holding workers back 3 to 4 months in their job search efforts. A similar pattern holds in experience years 5 and 6 , where overall mobility declines 2 percentage points, such that a 1 percentage point increase in mobility compares to a loss in job search of about 4-6 months. Thus, entering the labor market in a recession implies that workers lose about 4 months of search effort annually due to a bad initial start. ${ }^{50}$

Table 4 also reports effects on the cumulative fraction of workers who left the initial employer, as well as the propensity of change among 2-digit industry classes. While the effects on the rate of job change in columns (1) and (5) decline, the cumulated rate of departure from the $1^{\text {st }}$ employer in columns (2) and (6) increases permanently by about .3 to .5 percentage points. Interestingly, the effect of an early unemployment

by 0.002 smaller in absolute value than our main estimates, a difference that is not statistically significant. Note that, if at all, the figure suggests negative initial selection, possibly consistent with a certain degree of out-migration to the U.S. of high earners. This is consistent with small decline in average predicted earnings with experience in our sample.

49 The national results are in the Web Appendix. Including current unemployment rates interacted with experience to control for persistent local labor market conditions leads to a slight increase in the effect on job mobility (since for all but labor market entrants higher unemployment depresses voluntary mobility). This is another sign that the effects on mobility we obtain are stemming for voluntary mobility - in case of involuntary mobility, would have expected inclusion of additional unemployment controls to lower the estimates.

50 The initial increase in job mobility we find is of comparable size as the effect of a $10 \%$ reduction in wages found by Topel and Ward (1992), consistent with the magnitude of wage losses we find. 
rate on the frequency of 2-digit industry changes is almost as high as the frequency of changes in employers. Even mobility across 1-digit industries is relatively high (the coefficients are about three quarters the size of the coefficients for the 2-digit case in Table 4). This may either mean that the distinction among industries is meaningless in our sample, or that in addition to job shopping workers also actively search for a match with the 'right' industry. Several models of job search of younger workers would predict such a pattern (e.g., Neal 1995 or McCall 1990).

To what extent does the increased job and industry mobility contribute to the reversion of earnings losses? Clearly, the initial increase and gradual fading of mobility-responses with experience follow similar patterns as the change in the experience-earnings gradient. Mobility is likely endogenous itself, and thus we cannot 'condition out' the contribution of mobility on earnings effects of early unemployment rates. To gauge the potential of job and industry mobility to explain the observed earnings pattern, the upper panel of Table 5 shows the average earnings gain at job and industry changes by experience. Columns 1 through 5 show percentage annual earnings increases for movers and stayers, as well as for the full sample.

The purpose of this descriptive table is to characterize the association of mobility and wage growth without any causal interpretation. Similar to Topel and Ward (1992)'s results, the table documents a strong correlation between job changes and wage growth. On average, wage changes at job changes account for about $40 \%$ of overall wage growth in the first five experience years, and thereafter steadily declines to reach about $20 \%$ in experience year 10. Despite the differences in samples (their sample included workers of all education levels), these fractions are remarkably similar from what results in Topel and Ward (1992) and Giuliano and von Wachter (2005).

Earnings growth at job and industry mobility is $24 \%$ on average, and about double the growth for stayers from experience years 2 to 5 , and then 1.5 times thereafter. ${ }^{51}$ If one took this as a typical gain associated with a job change, then the estimated 1.5 point increase in job changes due to a 5 point recession shock could explain about $20-25 \%$ of the reversion of initial losses. (Table $5 \mathrm{~B}$ implies that an average increase in the rates of earnings growth for the first experience years due to 5 point initial UR shock is about 1.5-2 points.) Thus, job and industry mobility have the potential to explain an important fraction of the decay of initial job losses. However, the actual effect is likely to be larger since in a search framework the gains for workers starting at lower wages are likely to exceed those of the average.

To take this into account, the second panel of Table 5 presents models of the effect of initial unemployment rates on the rate of earnings growth by mover status. Due to selection into mover status, we cannot obtain a causal effect for wage growth of movers and stayers, neither is there a simple decomposition of the effect on total wage growth into the effects on its components. Instead, to complement the results in

\footnotetext{
${ }^{51}$ Experience year one includes transitions from jobs with half a year to jobs with a full year of earnings and thus is overstated. Note that these gains are higher than those found by Topel and Ward (1992) (Table VII), but they look at all workers and at quarterly earnings data.
} 
Panel A, the goal of Panel B is to assess whether the correlation of earnings growth and job mobility strengthens for workers entering the labor market in a recession. Column (1) shows that the effect on changes in earnings for the full sample is of similar magnitude as the corresponding level estimates in Table 1.52

Columns 2 and 3 show that the correlation between earnings growth and job mobility rises in recessions. This implies that the average earnings gains shown in Panel A are likely to understate the true gains of those moving jobs in response to a recession. Job movers have persistently higher wage gains than stayers in response to an initial unemployment shock, that is, job movers catch up faster from the initial loss. Columns 4 and 5 suggest that earnings gains at moves across industries are less precisely estimated, but follow a similar pattern. Table 6 also shows estimated gains from regional mobility. As discussed in the appendix, while the regional mobility appears conducive to wage growth, most of reversion of the losses from initial labor market shocks appears to take place within regions.

\subsection{Careers Between Firms}

The experience profiles in firm size and firm wages shown in Figure 1 suggests workers search for better employers over time. This is consistent with a growing literature documenting large difference in firms' wages not explained by worker and firm characteristics (e.g., Abowd, Creecy, Kramarz 2002, Idson and Oi 1999). A similar gradient arises if high wage firms gradually screen for more able workers among labor market entrants, either because of comparative advantage (Gibbons, Katz, Lemieux, Parent 2005) or because they thereby minimize the rents they pay (Lemieux 1998). 53 Adverse labor market conditions may impact these processes and reduce the quality of firms at which workers start their careers. Bils and McLaughlin (2001) find that better paying industries have pro-cyclical hiring patterns. ${ }^{54}$ Similar pattern are appear to hold for better paying or large firms; for example, this may arise due to changes in demand for products of different quality, differences in the costs of job creation, or because of changes in product market competition. In addition, it has long been speculated that firms raise their hiring standards in recessions (e.g., Hall 1974, Solon et al. 1997). This would lead to a temporary cyclical downgrading as workers tend to start at low wage firms.

Figure 4 (Panel C) and Table 4 show some evidence of this process with the estimated effects of early labor market conditions on the average firm sizes and average firm wages by experience year. Table 4 again shows results using regional unemployment shocks and for two samples. A reduction occurs in initial

\footnotetext{
52 The effects based on changes are slightly more persistent, partially due to a slight difference in samples as well as due to the implicit control for worker fixed effects in the wage growth model.

53 This process is reinforced if human capital increases with experience. Fox (2004) suggested that large firms will try to attract older, more experience workers because of span of control considerations. Or if, as in Neal (1998), high ability workers are better at acquiring specific human capital, and large high-wage firms value human capital more, over time more able workers will again transit to high wage firms. Alternatively, workers may start at low paying firms that allow for more general human capital investment on the job and then switch employers (Rosen 1972, Mincer 1974).

54 Typical high wage and pro-cyclical industries are durable goods manufacturing and construction. Typical low wage, less pro-cyclical sectors are retail trade or personal services.
} 
firm size that fades within four years; for the graduate sample in Column 5, a 5 percentage point recession reduces firm size by $4-5 \%$ in the first years. As the remaining columns and Figure 4 (Panel C) shows, there are much larger effects on the average median (log) wage of a worker's first employers. Column 7 suggests that the average median log wages of a workers' employer falls 3-5\% in the first years after entry into a 5 point recession. This effect declines to a $2 \%$ reduction in years 5 to 9 , and only fades by year 10 . Since the effect of average log payroll combines the effects on average size and average median wages, the effects are initially larger $(7-10 \%)$ than those on median earnings but decline more rapidly over time.

These numbers suggest that about $40 \%$ to $50 \%$ of the effect of an initial 5 point unemployment shock on wages shown in Table 1 (ranging from -.092 initially, to -.059 after 3 years and -.0365 after 7 years for the graduate sample) could be explained by reductions in the average wage of an employer. To gain further insight about the economic significance of these results, compare the effects of early recessions on average median firm wages with the experience profiles in firm 'quality' in Figure 1. The increase in average median firm wages due to experience is $8 \%, 6 \%, 4 \%, 4 \%$, and $2 \%$ from year zero to year five (in the graduate sample). 55 If workers search continuously throughout the year, and job search entails a continuous increase in firm size, then the effects of recessions set people back by about half a year in their job search process consistently in each of the first five years in the job market. ${ }^{56}$

It appears that a considerable part of earnings losses from graduating in a recession can be explained by the start of working life in lower paying industries and firms. Over time, affected workers improve their relative position vis-à-vis other more lucky workers by switching to better paying establishments. These moves entail switches across industries and across regions as well, but little losses in the time spent working. Thus, firms appear to play an important role in the determination of early wage growth and in the persistence of early labor market shocks on wages. This is consistent with a pattern of cyclical down- and upgrading of workers between industries and firm-types (e.g., Okun 1973). However, workers do not appear to be confined to their initial employer and can remedy an initial bad draw due to temporary changes in hiring standard in a recession by switching employers as the economy turns back to normal.

\subsection{The Role of the First Employer}

To further describe the career moves that lead to the catch-up up pattern observed in Figure 4 (Panel A), we assess the role of the initial employer in ensuing career outcomes. The results in the previous section in particular suggest that workers might lose initially due to access to firms that pay less and perhaps offers a less favorable career environment. To do so, we first include fixed effects for the first employer in the basic

\footnotetext{
${ }_{55}$ Relative to the increase in average firm size $(-4 \%, 7 \%, 4.4 \%, 1.3 \%$, and $4 \%$ in years 1 to 5 for the graduate sample), the effect of initial firm size sets workers back by about a little more than half a year.

${ }^{56}$ Similar results are also obtained for average one, two, and three-digit industry wage premiums, consistent with the fact that high wage industries have more pro-cyclical employment creation. However, changes in average industries wage premiums for labor market entrants can only partially explain decline in average firm wages (see the Web Appendix for direct estimates of changes of average industry wages).
} 
regression model, and also interact these fixed effects with unrestricted experience profiles. An interaction with experience also allows for shifts in experience profiles related to the choice of the first employer to account for heterogeneity in training or learning opportunities across firms. If all that happens is that workers search for rents, controlling for initial firm fixed effects should eliminate losses. Clearly, these results can only be indicative, since recessions are likely to change the ability of the marginal worker hired.

The results, shown in Figure 6A, suggest that wage losses for workers starting in a recession at a given firm relative to workers starting at better times are about $60-70 \%$ of original losses initially, and then decline to about $60 \%$ and fade completely after year seven. Thus, $30-40 \%$ of losses are driven by the choice of the very first employer alone (see also Appendix Table 6). Including an interaction with initial firm and experience effects does further reduce the initial earnings loss, but not by much. Thus, it does not appear that on average choice of initial employer is associated with different growth paths. Effects of first industry at the 2-digit level also explain a smaller but important part of the initial wage differences.

These results confirm that average wage differences between firms and industries play an important role in explaining persistent recession effects. Yet, there are important persistent effects left for workers starting at the same firm. This is not surprising since previous research have found firms do not fully shelter workers from external labor market conditions, specially for job changers (Solon et al. 1994, Devereux 2003). In addition, the empirical and theoretical literature suggests firms may have pro-cyclical internal job assignment (e.g., Okun 1973, Devereux 2005, Gibbons and Waldman 2004) or write contracts based on external market conditions (e.g., Beaudry and DiNardo 1991), potentially leading to persistent earnings effects within firms. These mechanisms should be particularly relevant for larger and high paying firms since despite reduced earnings workers may not have an incentive to change employers.

To gauge whether workers starting at large or high wage firms have more persistent wage losses due to unemployment rate shocks, we interacted a dummy for whether the first employer is large (firm size greater than 1000) or pays high wages (log median earnings greater than 75th percentile of distribution) with unemployment at time of graduation. We find that there's a substantial gain from starting at larger or high paying firms that is unaffected by early labor market conditions (Figure 6B). That is, relative to workers in the same firm type, the initial wage losses from starting in a recession are similar. However, the losses of workers starting at large, high wage firms are more persistent (i.e., the difference in losses between initial firm types turns significantly negative with experience).

Workers starting at large, high paying firms always benefit from a wage premium (about $15-20 \%$ for firms with 1000 or more workers, as in Oi and Idson (1999), and about 30-40\% for firms above the upper $75^{\text {th }}$ percentile of average log median earnings), but may be stuck with a worse contract, consistent with findings in Baker, Gibbs, and Holmstrom (1994). Workers starting at smaller, low wage firms are more likely to move and improve their position in terms of contract or firm type, consistent with the pattern documented 
in Section 4. Although none of the controls for selection bias we tried affected our results, it should be kept in mind that these results may partially be affected by differential hiring patterns over the business cycle. ${ }^{57}$

\section{Heterogeneity of Early Recession Effects}

\subsection{Larger Effects for Labor Market Entrants}

To put the magnitude of the shock in the initial period into further perspective, Figure 5 (Panel A) shows the dynamic effect of a shock occurring at experience years two to three from the grouped model with full history controls (Table 2, Column 7). To make the dynamic pattern comparable with that of the first group, the table shows coefficients relative to the time of the shock (i.e., experience zero now relates to the moment of the shock). The effect of a shock experienced at experience years 2-3 is much smaller than the effect of a shock at entry (0-1) for all experience years. Our period is too short to observe complete reversion but the point estimates are insignificant after 4-6 years. Inspection of the data leads us to believe that the dynamic effects for shocks at later experience years are small. ${ }^{58}$

To explore the difference between labor market entrants and more mature workers further, Table 6 analyzes the profile in the effect of unemployment rates on wages and other outcomes by five experience groups. To make our estimates comparable with the previous literature, we show effects of the natural logarithm of unemployment rates controlling for current province fixed effects. The upper panel uses the unemployment rate for workers age 15 to 24 and the lower panel considers the effect of unemployment rates for all workers. The first rows of Panel A and B show the effect of unemployment without experience interaction. The elasticities in the first row of Column 1 of the two panels essentially replicate the results typically found in wage-curve estimates. The remaining columns show the effects of unemployment on other outcomes; the remaining rows of the table show separate estimates by experience groups.

The table makes strongly confirms the exceptional role of labor market entrants vis-à-vis mature workers. First, in all estimates there is an important experience gradient in the effect of current unemployment rates. Thus, the pooled estimates in the first row potentially obscure important effects present in the data. Second, the initial effects in early experience years are the strongest across all groups. Unemployment conditions in the local labor market matter three to four times as much for labor market entrants than for young workers who already progressed into their career by a few years. Third, the estimated gradient is as expected from results of the previous literature. For example, job to job mobility of mature workers declines in recessions (Shimer 2005b), effects on non-employment are small, and average firm size rises for mature workers since smaller plants are more likely to close (Krashinsky 2002). Note that since later experience years pick up some of the persistent effect of the initial shock, the difference between the effect of

\footnotetext{
${ }^{57}$ We included several control functions based on the quadratic average father's income at the cell level and cell size, none of which turned out to be significant or to alter our results.

58 Our sample of cohorts is small at later experience years, such that the cohort variation shown in Appendix Figure 1 does not allow us to estimate the average dynamic effects of shocks at later experience years.
} 
unemployment at experience years 0-1 and 2-3 or later years is understated. A replication of the table with full dynamic controls yields qualitatively similar results but larger initial differences.

\subsection{Larger Effects for Entrants at the Bottom of the Skill and Earnings Distribution}

The baseline results reveal that, on average, individuals that graduate in high unemployment conditions experience lower relative wages and that this gap dissipates over a 10 year period. Consequences of graduating in poor economic conditions, however, might differ by innate ability or initial background characteristics. The most productive workers may possess superior skills or network connections that assist them to find higher paying jobs. Similarly, firms may have an incentive to hire more able workers if they pay wage premiums. While there are some estimates of recession effects for the very bottom of the skill distribution, less evidence exists for the importance of heterogeneity among higher-skilled workers. Moreover, very little is known about the degree of heterogeneity in the persistence of initial effects, or how different groups of workers catch-up after an initial shock.

These differences are of special interest for our purposes, because they provide an additional source of variation to assess the economic mechanisms underlying the adjustment process. Yet, they have been understudied because few data sources contain information on both employer quality and workers' earnings capacities. We use our data to examine whether college graduates with lower predicted wages, based on college background, are more adversely affected by higher unemployment rate conditions in terms of lower earnings and ending up at firms that tend to pay less. We first use an OLS model to predict log earnings based on college attended, program of graduation, and years of study, conditional on province of study and cohort year. ${ }^{59}$ Since individuals are likely to be sorted into colleges, these estimates will capture both differences in innate ability as well as differences in college quality. ${ }^{60}$ We then group individuals into quintiles based on these predicted wages.

Figure 7 shows the same coefficients for the effects of the initial unemployment rate on log earnings, job mobility, individual's firm's log median earnings, and employment as in the baseline model, but for the first, third, and fifth predicted wage quintiles (this figure corresponds to Figure 4 for the full sample). Table 7 summarizes the key structure of losses by quintile and compares them to results for the full sample. For the sake of exposition, the table displaces three parameter estimates for the initial dip, first recovery, and final

\footnotetext{
${ }^{59}$ A similar approach to assess college quality is followed by Betts, Ferrall, and Finnie (2000), who use the same college data and information on wages after graduation as we do. After analyzing majors and colleges separately, in our final specification we interact major and college dummies. The results by major are show in Appendix Figure 4 for earnings, the analysis for colleges and other outcomes is in the Web Appendix. Differences by major or college in itself are as expected (e.g., humanities graduates do worst, then come social sciences, economists and engineers are in the middle range), but too broad to yield a prediction of individual earnings capacity. This exercise is done for the graduate sample only, since it is conceptually harder to assign college quality for drop-outs.

${ }^{60}$ This is discussed extensively in Black and Smith (2003), Black, Kermit, and Smith (2005), or Dale and Krueger (2002). An advantage of our data relative to the literature on college quality in the U.S. is that we have access to earnings histories. Using the same data as ours, Betts et al. (2000) find that the effects of observable measures of college quality on earnings are small.
} 
fade of earnings losses in an approach mirroring that of Jacobson, Lalonde, and Sullivan (1993). As apparent from the table and figure, those with the lowest predicted annual earnings are most affected by higher initial unemployment conditions and experience permanent earnings losses. Earnings one year into the labor market are about 15 percent lower from a 5 percentage point increase in the initial unemployment rate, and, in this case, remain about 7.5 percent lower even after 10 years. The top quintile's earnings are about 7.5 percent lower, on average, in the first year out, but the gap falls to less than 2 percent after only 4 years.

The pattern is altered if we consider the effects on firm quality, as measured by the median wage paid at the firm. While those in the highest quintile end up in lower paying firms only for the first 4 to 5 years, firm quality is permanently worse among the lowest quintile. Different from before, the middle group sees quick initial improvements but lasting declines in firm quality (Panel C); nevertheless, earnings continue to rise and job mobility remains high (Panel B). Thus, while initial catch up is driven by improvements in firm size, continuing catch-up appears to be driven by beneficial job mobility within firm-classes.

These patterns are summarized in Figure 8 (Panel A). By deciles of predicted earnings, the figure shows the fraction of earnings losses that have faded after five years in the labor market, as well as the improvements in firm quality and the fraction of workers that left their first employer. Those deciles with highest rate of job mobility and larges changes in firm quality appear to have faster reversion of earnings. The correlations in the figure lend additional support to the result based on the average in our sample that increasing job mobility and improvements in firm quality are important channels of recovery from an initial recession shock. ${ }^{61}$

The longitudinal data also allows us to obtain a direct measure of the cost of recessions that is a useful complement to measures in the literature based on the standard deviations of earnings. Figure 8 (Panel B) graphs two summary measures of the present discounted loss due to entry into the labor market in a recession by deciles of the predicted earnings distribution. First, it plots the percentage decline in the present discounted value of annual earnings; second, it shows the fraction increase in annual earnings a worker would require to be indifferent between the noisy earnings path and an alternative, stable path. The latter corresponds conceptually to the original Lucas measure where we have replaced consumption by annual earnings and is comparable to several estimates of costs of recessions in the literature. ${ }^{62}$

Figure $8 \mathrm{~B}$ has two key messages. First, there is an important gradient in the cost of recessions in predicted earnings - those individuals with lower earnings capacity have four to five times costs of recessions than the most advantaged workers. The least advantaged appear to bear most of the costs of recessions.

\footnotetext{
${ }^{61}$ As Figure 7 (Panel D) shows, the lowest ability workers are an exception and tend to converge by improving labor force attachment relative to similar workers graduating in booms.

62 This approximation has clearly important flaws, since social insurance programs smooth temporary earnings shocks and may lead consumption to be less volatile than earnings. On the other hand, this might be less of a concern for highly educated workers whose take up of social programs is low. Here we follow the literature on the costs of recessions by approximating the risk faced by individuals with earnings risk. Cutler and Katz (1991) discuss the usefulness of earnings as a measure of inequality and the effects cyclical shocks.
} 
Second, the losses from starting to work in a recession as measured by actual changes in the present discounted values of earnings or utility losses are high even for the more able workers. In particular, they are much higher for the median worker in our sample than what is typically found in the literature. ${ }^{63}$

\section{Discussion of Career Models}

The preceding sections document several facts that a model of career determination should be able to explain. Although no single model is likely to explain all patterns or is completely rejected by the data, for most workers we find little evidence for either permanent scarring or short-term frictionless adjustment. Instead, a combination of models based on search and contracting frictions hold could explain the main pattern we find.

First, the persistence of a short-term initial labor market shock appears too high to be explained by the standard neo-classical model, especially once we control for persistence of unemployment shocks. Similarly, the standard model cannot explain the systematic responses of job mobility and firm quality, the fact that less advantaged college graduates are hurt more, and that labor market entrants fare significantly worse with young workers with two or three years of labor market experience. While each of these phenomena could be explained by an extension of the standard model, the balance of the evidence suggests important short- to medium run departures from a frictionless view of wage setting.

This conclusion is corroborated by the fact that the initial losses in employment we find appear too small to cause significant losses in general human capital accumulation. Analyzing survey information on weeks and hours worked, Kahn (2005) comes to a similar conclusion. Labor force attachment of male college graduates is very high even in recessions. Moreover, since our results persist even controlling for subsequent labor market shocks, it appears unlikely that continuing low economic activity within firms reduces the amount of learning-by-doing. ${ }^{64}$

A second important insight from our results is that the importance of job changes in early wage growth and the increase in job mobility for workers graduating in recessions suggests that initial losses occur due to a temporary worsening of the wage-offer distribution and a time-intensive search for a better job after the distribution has shifted back to normal. Topel and Ward (1992) and von Wachter and Bender (2006) suggest that the job shopping process can last 5 to 10 years. The heightened mobility across industries also suggests that workers actively modify their careers in response to an initial shock to avoid persistent losses.

\footnotetext{
${ }^{63}$ We find that an uncertain stream of earnings had to be increased by about $7 \%$ for the median worker in our sample to be of equal utility as a comparable certain path. The typical estimate in the literature is below 1\%. Some studies, such as Storesletten, Telmer, and Yaron (2001) or Krusel and Smith (1999) find effects comparable to ours for households with no wealth.

${ }^{64}$ We also find that a substantial fraction of improvements in wages occur at job changes, and that this correlation strengthens for workers graduating in a recession. This result and the persistence of losses from just a single initial shock also makes it appear unlikely that initial losses arise from lack of accumulation of firm or industry specific capital due to excess initial mobility. While Kahn (2005) finds no effect of recessions on job tenure, Devereux (2002) finds significant yet small effects. Due to measurement error in self-reported job mobility, to small sample sizes, and to the presence of cohort effects, the authors may obtain estimates that are likely to be imprecise and downward biased.
} 
This is consistent with Neal's (1999) concept of 'complex' job mobility according to which workers search both over careers and jobs. Since we observe that most job and career switches occur early, losses from career-specific capital are likely to be small.

Third, the positive experience gradient we find in firm wages and firm size suggests workers search for better firms over time. Building on a large literature documenting important differences in average firm wages (e.g., Dickens and Katz 1988, Krueger and Summers 1988, Abowd et al. 2002), our paper is the first to characterize the experience gradient in firm quality in detail, extending and complementing earlier analyses by Fox (2004). ${ }^{65}$ Consistent with a large literature documenting that high-wage sectors have more pro-cyclical job creation, we find that an important part of initial losses is due to a down-ranking of workers into smaller, less-paying firms. Graduates lose initially because they face a worsening distribution of firm quality in the market during a recession, a channel often invoked in the literature but not documented before in this detail (e.g., Cutler and Katz 1991, Hines, Hoynes, and Krueger 2002).

Consistent with these observations, we also find that catch-up from an early recession shock involves a systematic recovery in firm quality, a pattern not due to persistent labor market conditions. These results point towards an environment where young workers search for jobs in high paying firms and industries, and where wage losses and an important part of the ensuing convergence occurs through improvement in firm and industry characteristics. Such a process of temporary cyclical down-grading could either result from an environment in which certain sectors pay rents (Okun 1973, Krause and Lubik 2005), or from a situation in which workers of heterogeneous ability face firms with different payment structures (Mclaughlin and Bils 2001, Gibbons et al. 2005). ${ }^{66}$

Fourth, our results also suggest an important role for the presence of long-term contracts and careers within firms. This can explain the fact that labor market entrants suffer stronger earnings losses than workers who are already employed. It also suggests that contracts can explain an important part of the remaining persistence we find within firms. However, since the effects we find arise just from a single recession shock and are robust for detailed controls for unemployment history, in our sample initial shocks keep influencing contracts despite the advent of better labor market conditions (Beaudry and DiNardo 1991). The 'contract' view could also explain our finding that workers starting in large high wage firms have more persistent earnings losses from graduating in recessions. Since on average these workers benefit from significant wage premiums, this may explain the lack of mobility that must underlie persistent effects within firms. This

\footnotetext{
${ }^{65}$ Using three size categories in the Survey of Income and Program Participation Fox (2004) analyzes whether larger firms search for better (older) workers to fill higher-ranked positions. Similarly, high-wage firms may try to hire older workers to minimize rents paid. While these explanations are complementary to our story, they are unlikely to explain the whole experience gradient, since workers are often promoted internally into higher positions, something not captured by the experience profiles.

${ }^{66}$ While we cannot rule out an explanation based on sorting and employer learning, it is not clear why information losses in recessions should down-rank the average worker; similarly, without additional assumptions a model of sorting cannot explain positive gradients in firm characteristics.
} 
suggests that the pattern of permanent firm-entry cohort effects found by Baker, Gibbs, and Holmstrom (1994) are concentrated at very large, high paying firms.

A fifth insight from our results is that there is important heterogeneity in the long-term costs of recessions, even among college graduates. ${ }^{67}$ These differences suggest that firms raise their hiring standards in recessions and that wages deviate from marginal products. ${ }^{68}$ Our results also imply that the pattern of catchup differs among high and low wage workers. While the majority of the population catch-up by switching to better employers, in particularly in the first years after labor market entry, the bottom $20 \%$ is permanently down ranked to lower quality firms (as predicted by Okun 1973). These workers still see some reversion of initial losses, partially due to an increase in labor supply. Since low-wage occupations and industries are typically less pro-cyclical, these differences are unlikely to be driven by skill-specific demand shocks.

\section{Conclusion}

We have estimated the long term effects of entering the labor market in a recession for a large sample of Canadian men leaving college whose earnings, employers, and career outcomes are tracked for ten years. Our main results suggest that the average worker graduating college in a recession faces earnings losses that are very persistent but not permanent. On average, a two standard deviation increase in the unemployment rate (roughly comparing the difference between those exiting college in a bust versus boom) leads to an initial wage gap of about 10 percent. This gap declines relatively slowly, and fades to zero after about the eighth year. Controlling for unemployment rate conditions after the first year of labor market entry, we also conclude that virtually all of the wage deficit can be attributed to the unemployment rate variation in the very first year after leaving school. The results are robust to selective graduation or selective labor force participation, and to the many alternative specifications we tried.

We have also analyzed the possible sources of these losses, and how workers that graduate in a recession eventually catch-up to their counterparts that graduate in a boom. Job and industry mobility rise initially and decline gradually in response to an initial adverse shock, implying that exiting college in a recession reduces the quality of initial job matches. However, job moves are highly productive for the young

\footnotetext{
${ }^{67}$ Changes in the decomposition of employers over the business cycle are also often observed in the academic labor market for economists. In particular, while the type of jobs available across the cycle varies little for the top graduate students, it is matters a lot for the median student or the lower tail. The analogy to the wider labor market is imperfect, however, since job mobility and the access to alternative employers for the average economist in the first years of the career is much lower. Not surprisingly, as found by Oyer (2005), cyclical swings in the market for graduates from top Ph.D. programs lead to persistent declines in productivity.

${ }^{68}$ Any model in which wages contain rents that decline with worker ability implies high-wage firms selectively hire more able workers and reduce employment of less able workers first in a downturn (e.g., Lemieux 1998). A cyclical adjustment of hiring standards has been often noted (e.g., Reder 1955, Hall 1974), and it has often been suggested that a loss in job quality is an important feature of recessions for less skilled workers (e.g., Okun 1973, Hines et al. 2002). It is more difficult to explain this phenomenon in equilibrium models of wage determination in which wages always equal marginal product. While for employed workers complementarities between specific skill accumulation and general ability may reduce the job stability of less able workers (Neal 1998), this is less relevant for labor market entrants. Counter-cyclical demand for skilled labor could explain the patterns observed in the data.
} 
graduates in our sample, and this association strengthens for workers affected by adverse early market conditions. Calibrating the effects of job search using estimates of average wage gains of moving by experience, we find that increased job search can explain about 30\% of the reversion in initial wage losses.

Consistent with a pattern of increased productive job mobility, we find that recessions lead workers to start at employers that are on average smaller and pay less. Possibly due to a lack of information on firms, few papers document that workers seem to face positive experience profiles in firm-size and average firmwages. We document this pattern, compare it to similar data for the US, and show that declines in the size and average wages of first employers of young college graduates could explain about 30 to $40 \%$ of initial wage losses from starting a career in a recession. Labor market entry in bad times leads to worse job placement or mis-matches of workers into firms, and workers catch-up by searching for or sorting themselves into better establishments. Such a process of cyclical up- or down-grading could either result from an environment in which certain sectors pay rents (e.g., Okun 1973), or from a situation in which workers of heterogeneous ability face firms with different payment structures (e.g., Gibbons, Katz, Lemieux, and Parent 2005). As suggested by Freeman (1975) and Katz et al. (1995), these patterns are strongest for young workers, while older workers are less affected by recession shocks.

We also find that college graduates at the bottom of the wage and ability distribution have larger and more persistent losses, while the effects at the top are small and short lived. Our estimates of the path of earnings declines suggests that the present discounted value of losses in annual earning or utility could be three to four times larger for the least relative to the most advantaged workers, indicating that even within the group of college graduates there is a large degree of heterogeneity in the costs of recessions. Patterns across deciles of the distribution of predicted wages support the importance of job mobility and changes in firm quality, with exception of those least advantaged, who suffer permanent earnings losses and are permanently down-ranked to lower wage firms. 


\section{Data Appendix}

Our data combines three administrative datasets from Statistics Canada. The first is the University Student Information System (USIS), which includes enrollment and graduate information of post-secondary students in Canada from 1974 to 1997. We augment the USIS data by linking it to income data from the T1 Family File (T1FF) between 1982 and 1999, and to an employer-employee matched dataset called the Longitudinal Employment Analysis Program database (LEAP). Each is described below, followed by how we defined the variables used in our analysis.

USIS is a national database containing pertinent up-to-date information on student participation in and graduation from Canadian degree granting institutions obtained from administrative records provided at the individual level. USIS has two main components. The enrolment survey collects information on student counts, and requests information on a broad array of student and program characteristics including institution, province, gender, age, mother tongue, immigration status, country of citizenship and country of origin, full- or part-time status, type of qualification sought (e.g., bachelor, masters, etc., or none), field of study, year of study in program and an individual identifier. The degrees survey collects information on all students who have received a degree, diploma or certificate during the calendar year. The degrees survey has a more limited number of data elements than the enrolment survey. These datasets have been merged by the Education, Culture and Tourism Division of Statistics Canada, creating a third file commonly referred to as the linkage file. We use the linkage file in this analysis.

The information is obtained from the administrative records of Canadian degree-granting institutions, generally in an individual record format. Approximately 70 percent of post-secondary institutions provided regular annual individual information, including student identifiers that allow matching to the other two administrative datasets. We therefore focus on students from these institutions. ${ }^{69}$ All information in the USIS are checked for validity edited by the universities and, in some cases, by the province and by Statistics Canada.

The enrolment survey collects information on student counts as of December 1st in all provinces except Ontario, where the reference date is November 1st. This means that each student who attends university in the fall session is counted only once annually, even though the student may be enrolled in more than one program. This student count is used as a proxy for the total number of students enrolled during a complete academic year.

The degrees survey collects information on all students who have received a degree, diploma or certificate during the calendar year ending in December. It is a count of the number of degrees, diplomas and certificates awarded, not the number of individual students who receive them.

${ }^{69}$ For more on the USIS and the match to the T1FF, see Heisz (2001) and Heisz (2003). 
From the enrolment data, we keep all males that began a full-time undergraduate program at a postsecondary school institution between the ages of 17 and 20. We note students' graduation date, or last year enrolled full time (plus one since enrolment was recorded as of December 1). Experience is defined as number of years since graduation or number of years since ending full-time post-secondary education. We examine earnings starting when experience equals zero, since students are likely to have worked for 7 months since graduation. We remove any student taking longer than 8 years to complete an undergraduate degree (dropping less than 1 percent of the sample). We also calculate predicted graduation year based on entry year plus four.

The enrolment data includes information on home province. If missing, home province was assumed to be the province of the institution the student began their program. After finding that national and regional unemployment rates at time of graduation were not correlated with obtaining a subsequent degree, we focus on students that obtain no more than one degree.

The post-secondary students we examine from the USIS are matched to the T1FF using the student identifier. The T1FF is a data set of individual tax records from 1982 to 1999. The T1FF includes information on earnings, defined as the sum of taxable earnings from employment and self-employment. The dataset also contains information on transfers, as well as age, gender, residential address and an identification number for the firm at which the individual is employed. Some students (fewer than 15 percent of the sample) were not matched, mostly due to missing identifiers. Missing ID may be because (1) the student did not have an IDcode (perhaps because he or she was a foreign student), (2) the student had an ID code, but either did not give it to the institution or the institution did not request it, or (3) the institution collected the ID code but did not report it on the USIS survey. To remove individuals that have left the country, we drop any student that does not file in the last two years of the T1FF data.

The cross-section outcome variables we examine include whether a student receives a degree, and years in post-secondary school. The annual outcome variables we focus on are log earnings, dummy variables for not filing taxes, zero earnings, and living in different province than initial province.

Individuals working in the USIS-T1FF are also matched annually to information about their firms from Statistics Canada's Longitudinal Employment Analysis Program database (LEAP), beginning in 1983. The match rate was 96 percent. $^{70}$ LEAP is a company-level database that includes all employers in Canada, both corporate and unincorporated. The database tracks the employment and payroll characteristics of

\footnotetext{
${ }^{70}$ In the case of multiple employers, the main employer is the one from which a worker has the most earnings. In defining our mobility measures, we have taken particular care with missing values for firm identifiers and industry codes. To address the problem of missing values, we first fill in single missing values with the adjacent past firm identifier or industry code. We then estimate a conservative and a more inclusive measure of mobility. The first only considers changes between two valid firm identifiers or industry codes. The second treats remaining missing values as a job or industry change. The two measures approximate upper and lower bounds of job mobility.
} 
individual firms from their year of entry to their year of exit. ${ }^{71}$ Employers in Canada are required to register a payroll deduction account and issue a T4 slip to each employee that summarizes earnings received in a given fiscal year. The LEAP database includes every business that issues a T4 taxation slip.

The LEAP includes a 3-digit industry code and information on annual firm size and total payroll amounts. We recorded average firm size, and total firm size between 1982 and 1999, and also subtracted the mean amounts for each year before averaging. Both methods produced similar results. ${ }^{72}$ We also recorded when individuals switched firms and industries.

The data are collapsed into cell means by home province, year left post-secondary education, predicted year left post-secondary education, and experience. The cell means are matched to national and provincial unemployment rates both at time of school exit and predicted school exit. We use Statistics Canada's youth unemployment rate (ages 16 to 25). Results with the full unemployment rate were similar.

We work with two samples - the two-way student-earnings match, and the three-way match that also includes firm variables. The main results are obtained on the former, but estimates differ little between the two samples. To maximize the range of cohorts with as much as possible experience history we focus on the full range of graduation cohorts that we can match to unemployment rates at time of labor market entry (1976-1995). In the empirical analysis, we also report alternative results with subsets of cohorts. Appendix Tables $2 \mathrm{~A}$ and $2 \mathrm{~B}$ show sample sizes of the two-way match by graduation and experience year for graduation cohorts from 1977 to 1995 (including and excluding observations with missing earnings).

\section{Sensitivity Appendix A: Accounting for Selective College Graduation}

The decision to leave college may be a function of the business cycle. ${ }^{73}$ If workers postpone college exit in recessions, we would expect that the unemployment rate in the year of predicted graduation is positively related to college duration. Similarly, since workers with shorter durations are more likely to be able to further postpone graduation labor market entrants in a recession are more likely to have longer durations. Appendix Table 6 shows the effects on various basic measures of college duration of the national and regional unemployment rates, as well as of predicted regional rates, separately for all workers and for those at least on grade. We see no significant correlations at the national level or for regional unemployment at the time when workers should have graduated were they on grade. However, we see some significant effect of early

\footnotetext{
71 The self-employed that do not draw a salary are not included on the LEAP database. In addition, businesses comprised solely of individuals or partnerships who do not draw a salary are also excluded from the LEAP.

72 The USIS industry code is documented in Statistics Canada's USIS user guide, 1995.

${ }^{73}$ College enrollment decisions also depend on the state of the local labor market. However, the effects appear to be small in the U.S. since the 1960s (e.g., the fraction of men age 19 to 21 in college is not affected by the unemployment rate for mature workers, see Card and Lemieux (2000) Table 4, nor is the proportion of workers who finish $12^{\text {th }}$ grade and start college (Table 5). The unemployment rate at age 17 does not affect the probability of having a college degree, but raises the fraction of workers with some college (Table6)). Note that if unemployment triggers entry into college of workers with particular unobserved characteristics, this could affect our instrumental variable strategy even if workers are not forward looking due to correlation of the unemployment rate at entry and at exit. However, as shown in the next section, most of the correlation of unemployment rates fades after three years.
} 
unemployment rates at actual graduation with duration. For a five percent change in unemployment rates, this would imply an increase of 2.5 percentage points $(10 \%$ relative to the 0.26 average shown in Appendix Table 1).

Panels D to F of Appendix Table 7 show the same specifications for those workers on or above grade (see also the appendix available on our website for more detail). The effects are somewhat smaller. A five point shock to unemployment implies a 0.05 increase in average years of college (corresponding to three weeks or $1.4 \%$ relative to a mean of 4.11 years). These results suggest that a very small fraction of workers who are barely on or above grade tend to extend their stay in college by one or two years. ${ }^{74}$ The fact that unemployment at predicted graduation matters less suggests this is driven primarily by workers who are already beyond grade. Consistently, the fact that the results are even weaker for the full sample and the fact that being on or above grade is not affected indicates that students overall do not make significant attempts to avoid leaving school in a recession by delaying graduation or enrolling in a new program. ${ }^{75}$

To directly address endogenous college exit we instrument unemployment in the actual year of exit with unemployment in the predicted year of exit based on official degree duration. Predicted year of exit is a valid instrument for actual year if college entry is uncorrelated with unemployment rates in the year of predicted exit, if it has no direct effect beyond the actual unemployment rate, and if it correlates with unemployment at actual exit. We believe the exclusion restrictions are valid, since even if students wanted, given the covariance structure of unemployment rates it would be hard for them to forecast future unemployment rates. The case could be made that the unemployment rate at predicted graduation could in itself be viewed as the relevant 'shock' to workers' careers. Thus, we present and discuss both reduced form and instrumental variable (IV) estimates.

The first two columns of Appendix Table 8 present the reduced form estimates of the interactions of potential labor market experience for the same specifications as in Table 1 (OLS). Columns 3 and 4 shows the IV results and the coefficients on the instrument from the corresponding first stage. The reduced form estimates are either equal (all workers) or slightly smaller (graduates) than the corresponding OLS estimates. The numbers in Appendix Table 7 imply that delayed entry is unlikely to affect the estimates of the catch-up

\footnotetext{
${ }^{74}$ Additional results in an appendix available on our website suggests that for this sample the probability of being above grade 1-3 years is raised marginally. Taking the results from Panel F, if $0.85 \%$ of workers stay longer and raise average college duration by 0.0056 years, the average additional time spent in college must be more than one year.

${ }^{75}$ Note that as pointed out in Section 2, the propensity of obtaining a graduate degree is also not affected by the unemployment rate in the year of the first exit from college (a 5 point unemployment shock leads to an increase in the probability to obtaining a post graduate degree of 0.008 , relative to a mean of 0.2 , with the lowest p-value of 0.157 in the regional sample for all workers). Post-graduate degrees are specially concentrated in the health professions, social sciences, and other majors (25-30\% of all graduates obtain a graduate degree) and less concentrated in business, engineering, and teaching (8-12\% obtain a graduate degree). Our sample restriction tends to more heavily exclude health profession and the social sciences than economics and engineering. To assess whether for some of these subjects the propensity to obtain a higher degree responds more strongly to unemployment at time of graduation, we ran the regressions by major. Social sciences is the only major experiencing consistent increases in the fraction of post-grad degrees during recessions, while health professions experiences consistent declines. All other majors show no clear patterns.
} 
pattern in the reduced form. The first stage coefficient is highly significantly different from zero and different from one. The ensuing IV results are either the same as OLS (for those on/above grade), or slightly more negative and more persistent (for all workers). All IV coefficient estimates are well within the confidence intervals for OLS results. ${ }^{76}$ Since the general effects of unemployment rates on labor market entry are quite small, it would have been surprising to find much of a difference. We conclude that OLS is appropriate to analyze the effects of early labor market conditions on the long-term career outcomes of Canadian college graduates.

\section{Sensitivity Appendix B: Accounting for Labor Market History}

All estimates presented so far represent summary effects of the dynamic impact of the initial unemployment rate plus the dynamic effects of ensuing unemployment rates that correlate with the first. They characterize the expected earnings loss of a worker graduating in a recession and help to assess the implications of different models of career determination. Another estimate of interest is the long-term impact of an isolated temporary shock of labor market conditions for individuals entering the full-time labor market for the first time, holding all else constant. This effect can also be compared to similar shocks at later experience years to benchmark whether initial shocks, when virtually all labor market entrants must search for employment, generate different permanent and transitory effects than subsequent shocks.

Since the current province of residence is available from income tax records, we can use our data to construct unemployment rate histories for each individual starting in 1982. We interact these histories with unrestricted experience dummies and include them into the basic model as additional control variables to isolate the effect of the unemployment rate at time of college exit. Since we only have complete data for 'market history' of individuals graduated starting in 1982, we focus on this restricted group of cohorts. ${ }^{77}$ Although shocks are highly persistent initially, the auto-covariance structure dips to zero after three to four years. ${ }^{78}$ Thus, the inclusion of two to three lags should suffice to absorb most of omitted variable bias.

Table 2 shows a series of models with augmented controls for unemployment history, each interacted with experience. The table shows the basic regional model with the graduate sample for two models with outcomes recorded between 1982 and 1995. To compare similarly defined unemployment

\footnotetext{
${ }^{76}$ Note that Hausman tests cannot be read off the tables since standard are clustered at either graduation cohort or graduation cohort-initial province level. Although we could implement a test based on Davidson and McKinnon's (1989) approach, we believe that the differences so small that it would not reverse our conclusions.

77 As shown in Appendix Figure 1, this group of cohorts has slightly more persistent effects of initial labor market conditions. We have also experimented with including cohorts with incomplete unemployment histories. The results, available in an Appendix on our website, are qualitatively the same. We also included unemployment histories based on unemployment rates for all workers, with no differences in the results.

${ }^{78}$ If as commonly done we specify the time series process of the unemployment rate as an $\operatorname{AR}(2)$, the coefficients are 0.87 and -.158 for the first and second lag, respectively, in a sample pooling all states and including year and state fixed effects (a procedure followed by Blanchard and Katz 1992). Figures of the auto-covariance structure and further discussion are available in an Appendix accessible on our website.
} 
shocks, all models include current province fixed effects. ${ }^{79}$ The first model includes the unemployment rate at the current experience year interacted with experience dummies, without additional labor market history. As expected, this has some small initial effects for experience years one to three, but little thereafter. Given that each of these unemployment rates has itself a potentially dynamic effect, the next models include interactions of these unemployment rates with experience dummies.

The first model, shown in Column 3 of Table 2 only includes dynamic effects of unemployment rates occurring in experience years one to three. The result shows an increasing spread in the two estimates that flattens out after experience year 5, exactly as predicted by the omitted variable bias calculations in Section 2 . At each experience year the worker is exposed to additional shocks correlated with the initial shock that in itself have dynamic effects, leading to an increasing bias; as the effects of shocks decline for mature workers (as shown in Table 7) and the correlation with unemployment fades or becomes slightly negative, the size of the gap stabilizes. Towards experience year eight the estimates become imprecise as the number of cohorts decline. The next model in Column 4 includes the entire interacted history for each experience year from one to ten. As predicted, the model is extremely similar to the one in Column 3 (however, the joint hypothesis that all additional coefficients or that all dynamic effects at higher experience years are jointly equal to zero is rejected by an F-test). Overall, the effect of the unemployment rate a worker faces in the year of college entry has a long term effect even when controlling for unrestricted dynamic effects of each single unemployment shock experience afterwards.

Since the estimates at later experience become imprecise, we now turn to a grouped model. We restrict the dynamic effects to be equal in two-year intervals (i.e., the effects of the unemployment rate at experience years $0-1,2-3,4-5$, etc., is constrained to be equal). To keep the size of the coefficients comparable to that of the main model, we take the averages of unemployment rates within groups (the results are the same if we were to compare coefficients at two standard deviations of the respective regressors). The fully interacted model with grouped unemployment rates then is

$$
\log \bar{w}_{c r t}=\phi_{t}+\theta_{r}+\chi_{c}+\gamma_{e}+\beta_{e, 0}\left(U R_{c r 0}+U R_{r_{1} 1}\right) / 2+\beta_{e, 1}\left(U R_{r_{2} 2}+U R_{r_{3}} 3\right) / 2+\ldots+u_{c r t} .
$$

Our data does not allow us to estimate the dynamic effects of unemployment shocks at experience years greater than three with a sufficient degree of precision due to a declining number of cohorts. ${ }^{80}$ Thus, we present dynamic estimates for groups $0-1$ and 2-3, and include additional dynamic interactions as controls for omitted variable bias. The dynamic effect at experience year 2-3 will help us to give a benchmark for the size of the impact of initial labor market conditions.

\footnotetext{
${ }^{79}$ As shown in Appendix Figure 1 and discussed in Section 3, this has little bearing on our original results. 80 Thus, dynamic estimates for unemployment shocks at higher experience years pick up the behavior of a limited number of cohorts. While interesting in its own right, the analysis of single cohorts is left to a separate study.
} 
The effect of a single shock at experience zero and the effect of the average unemployment in experience years zero and one are very similar. The last columns of Table 2 then show the model with fully interacted controls for grouped unemployment history. The coefficient estimates are graphed in Figure 4 (Panel A). The effect of omitted variable bias is again as predicted. Moreover, now the estimated effects are smooth and show a similar convergence pattern as before. ${ }^{81}$

\section{Sensitivity Appendix C: The Role of Regional Mobility}

In columns 6 and 7 of Table 6, we compare the effect of initial unemployment rates on the gains from regional mobility by experience. Interestingly, while regional movers gain more if affected by an early recession initially, these gains fade after experience year three. It is those who stay in the region or residence who have consistently higher earnings growth. Thus, while regional mobility may still be as beneficial in booms as in recessions, it appears regional movers do not have permanently higher rates of catch up than regional stayers. That gains at regional mobility are not as exceptional as gains at job or industry moves also results from the fact that average earnings growth for region movers and stayers is quite similar, as shown in the last columns of Panel A.

It appears that regional mobility is not as important in Canada as in the U.S. (Waggoner 2004). To further explore whether the higher job mobility for workers entering the job market in recessions is associated with higher mobility across provinces, the last columns of Table 3 shows the effects of the unemployment rate at college exit on subsequent provincial mobility. The national unemployment rate is uncorrelated with moving to other provinces for both the full sample and graduate sample in Columns 5 to 6 respectively. The results here suggest no inter-provincial mobility response from worsening in overall economic conditions. For the regression models identifying regional economic shocks, however, we do observe initially increased provincial mobility for cohorts exposed to higher unemployment conditions at time of college exit. For the graduate sample, a 5 percentage point difference in the unemployment rate at entry is associated with about a .75 percentage point difference in the provincial mobility rate in the first two years. This rate is about half that for firm mobility, and drops quickly after the third year. ${ }^{82}$ The small effect of unemployment at college exit on provincial mobility suggests that most of the pattern of catch-up in wages over time for individuals that began the labor market in a recession occurs within provinces.

\footnotetext{
${ }^{81}$ If we repeat the exercise with the full set of cohorts (for which we do not have complete history controls) the results are very similar for the grouped model, with complete convergence occurring after six years in the labor market (shown in an Appendix Figure available on our website).

82 After the fifth year out of college, the unemployment rate at time of exit is negatively correlated with provincial mobility. Those induced to move to another province from entering the local labor market during high unemployment appear to be less likely to move thereafter. We also replicated our estimates separately for workers who never switch region and for movers. Those never moving, about three quarters of our sample, behave very similar as the full sample (see Web Appendix).
} 


\section{References}

Aaronson, Daniel and Sara Christopher (2004). "Employment Growth in Higher-Paying Sectors." Chicago Fed Letter (206): Federal Reserve Bank of Chicago.

Abowd, John, Francis Kramarz, and David Margolis (1999). 'High Wage Workers and High Wage Firms.' Econometrica 67(2): 411-45.

Abowd, John, Robert Creecy, and Francis Kramarz (2002). 'Computing Person and Firm Effects Using Linked Longitudinal Employer-Employee Data.' Cornell, mimeo.

Abraham, Katherine and John Haltiwanger (1995). 'Real Wages and the Business Cycle.' Journal of Economic Literature 33(3): 1215-1264.

Acemoglu, Daron (2001). 'Good Jobs vs. Bad Jobs.' Journal of Labor Economics 19 (1): 1-21.

Akerlof, George A. and Janet L. Yellen (1985). 'A Near-Rational Model of the Business Cycle, with Wage and Price Intertia.' The Quarterly Journal of Economics 100(5): 823-838.

Akerlof, George A., Andrew Rose, and Janet L. Yellen (1989). 'Job Switching and Job Satisfaction in the U.S. Labor Market.' Brookings Papers on Economic Activity 1988 (2): 495-594.

Albaek, Karsten and Bent E. Sorensen (1998). 'Worker Flows and Job Flows in Danish Manufacturing.' The Economic Journal 108(November): 1750-1771.

Anderson, Patricia M. and Bruce D. Meyer (1994). 'The Extent and Consequences of Job Turnover.' Brookings Papers on Economic Activity. Microeconomics: 177-236.

Baker, George, Michael Gibbs, and Bengt Holmstrom (1994). 'The Wage Policy of a Firm.' Quarterly Journal of Economics 109: 881-919.

Barlevy, Gady (2005). 'The cost of business cycles and the benefits of stabilization.' Economic Perspectives Chicago Federal Reserve 1st Quarter.

Barsky, Robert and Gary Solon (1989). 'Real Wages Over the Business Cycle.' NBER Working Paper 2888.

Beaudry, Paul and John DiNardo (1991). 'The Effect of Implicit Contracts on the Movements of Wages over the Business Cycle' Journal of Political Economy: 99(4).

Beaudry, Paul and David Green (2000). 'Cohort patterns in Canadian earnings: assessing the role of skill premia and inequality trends.' Canadian Journal of Economics 33 (4): 907-936.

Beaudry, Paul, Thomas Lemieux, and Daniel Parent (2000). 'What is Happening in the Youth Labor Market in Canada?' Canadian Public Policy, XXVI Supplement 1.

Becker, G. (1964). Human Capital: A Theoretical and Empirical Analysis with Special Reference to Education. New York: Columbia University Press.

Betts, Julian, Christopher Ferrall, and Ross Finnie (2000). 'The Role of University Quality in Determining Post-Graduation Outcomes: Panel Evidence from Three Recent Canadian Cohorts.' Mimeo.

Bils, Marc. J. (1985) 'Real Wages over the business cycle: Evidence From Panel Data.' Journal of Political Economy, 666-689.

Black, Dan, Kermit Daniel and Jeffrey Smith (2005). "College Quality and Wages in the United States." German Economic Review 6(3): 417-445.

Black, Dan and Jeffrey Smith (2004). "How Robust is the Evidence on the Effects of College Quality? Evidence from Matching." Journal of Econometrics. 121(1): 99-124.

Blanchflower, David G. and Andrew J. Oswald (1994). The Wage Curve. Cambridge, MA: MIT Press.

Blanchard, Olivier and Lawrence Katz (1992). 'Regional Evolutions.' Brookings Papers on Economic Activity, 1: 1992, pp. 1-75. 
Bloom, David E. and Richard B. Freeman (1986). 'The 'Youth Problem': Age or Generational Crowding.' NBER Working Paper No. 1829.

Burdett, Kenneth (1978). 'A Theory of Employee Job Search and Quit Rates.' American Economic Review 68(1): 212-20.

Card, David (1995). 'The Wage Curve: A Review.' Journal of Economic Literature 33 (June): 785-799.

Card, David, and Thomas Lemieux (1997). 'Adapting to Circumstances: The Evolution of Work, School, and Living Arrangements Among North Amercian Youth.’ NBER Working Paper No. 6142.

Card, David, and Thomas Lemieux (2000). 'Drop Out and Enrollment Trends in the Post-War Period: What Went Wrong in the 1970s?’ NBER Working Paper No. 7658.

Card, David, and Thomas Lemieux (2001). 'Can Falling Supply Explain The Rising Return To College for Younger Men? A Cohort Analysis.' Quarterly Journal of Economics, May.

Davidson, R., and J.G. Mackinnon (1989). ‘Testing for consistency using artificial regressions.' Econometric Theory 4: 363-84.

Cutler, David and Lawrence Katz (1991). 'Macroeconomic Performance and the Disadvantaged.' Brookings Papers on Economic Activity 1991 (2): 1-74.

Dale, S. B. and A. Krueger (2002). 'Estimating the payoff to attending a more selective college: an application of selection on observables and unobservables.' Quarterly Journal of Economics 117, 1491-1528.

Deaton, Angus (1997). The Analysis of Household Surveys. Johns Hopkins University Press.

Devereux, Paul (2001). 'The Cyclicality of Real Wages within Employer-Employee Matches.' Industrial and Labor Relations Review (54)4: 835-850.

Devereux, Paul (2002). 'Occupational Upgrading over the Business Cycle.' Labour 16 (3) 423-452.

Devereux, Paul (2003). 'The Importance of Obtaining a High-Paying Job.' Mimeo, University of California, Los Angeles.

Dickens, William T. and Lawrence F. Katz. 'Inter-Industry Wage Differencesand Industry Charachteristics.' Unemployment and the Structure of Labor Markets, edited by K. Lang and J. Leonard, pp. 48-89. New York: Basil Blackwell, 1987

Doeringer, Peter and Michael Piore (1971). Internal Labor Markets and Manpower Analysis. Lexington, MA: D. C. Heath and Company.

Farber, Henry (1994). 'The Analysis of Interfirm Worker Mobility.' Journal of Labor Economics 12: 554-93.

Farber, Henry (2003). 'Job Loss in the United States, 1981-2001.' IRS Working Paper No. 471 Princeton University.

Freeman, Richard B. (1975). 'Overinvestment in College Training.' The Journal of Human Resources 18(2): $287-$ 311.

Freeman, Richard B. (1979). 'The Effect of Demographic Factors on Age-Earnings Profiles.' The Journal of Human Resources 14 (3): 289-318.

Freeman, Richard B. (1981). 'Career Patterns of College Graduates in a Declining Job Market.' NBER Working Paper 750.

Fox, Jeremy (2004). 'Employer-Size Wage Gaps, Testing Worker Preferences and Talents Explanations.' Chicago, mimeo.

Gardecki, Rosella and David Neumark (1998). 'Order from Chaos? Effects of Early Labor Market Experiences on Adult Labor Market Outcomes.' Industrial and Labor Relations Review 51(2): 299-322. 
Gibbons, Robert and Lawrence Katz (1992). 'Does Unmeasured Ability Explain Inter-Industry Wage Differentials.' Review of Economic Studies 59 (3): 515-535.

Gibbons, Robert, Lawrence F. Katz, Thomas Lemieux, and Daniel Parent (2005). 'Comparative Advantage, Learning, and Sectoral Wage Determination.' Journal of Labor Economics October 1-54.

Gibbons, Robert and Michael Waldman (1999). 'Incentives in Organizations.' In: Ashenfelter, Orley and David Card (eds), Handbook of Labor Economics. Elsevier Science Publishing Company Amsterdam, New York, and Oxford.

Gibbons, Robert and Michael Waldman (2004). 'Task-Specific Human Capital.' AE A Papers and Proceedings May, 94 May, pp. 203-207.

Giuliano, Paola and Till von Wachter (2004). 'Does a Four Fold Does a Four-Fold Higher Unemployment Rate Make a Difference? Wage Growth and Job Mobility of Young Workers in France and Germany.' Columbia University, mimeo.

Hall, Robert E. (1974). 'The Process of Inflation and the Labor Market.' Brookings Papers on Economic Activity 1974 (2): 343-393.

Hall, Robert E. (2005a). 'Employment Efficiency and Sticky Wages: Evidence from Flows in the Labor Market.' Forthcoming Review of Economics and Statistics, August.

Hall, Robert E. (2005b). 'Employment Fluctuations with Equilibrium Wage Stickiness.' Forthcoming American Economic Review.

Harris, Milton and Bengt Holmstrom (1982). 'A Theory of Wage Dynamics.' Review of Economic Studies 49: $315-333$.

Hines, James, Hilary Hoynes, and Alan Krueger (2002). 'Another Look at Whether a Rising Tide Lifts All Boats.' in Alan Krueger and Robert Solow. (Eds.), The Roaring Nineties: Can Full Employment Be Sustained? Russell Sage Foundation: New York.

Hildreth, Andrew, and von Wachter (2005). 'Estimating the 'True' Cost of Job Loss: Evidence Using Matched Data from California 1991-2000.' Mimeo, Columbia University.

Hoynes, Hilary (2000). 'The Employment and Earnings of Less Skilled Workers Over the Business Cycle.' In Rebecca Blank and David Card (Eds.), Finding Jobs: Work and Welfare Reform. Russell Sage Foundation: New York.

Jacobson, Louis, Robert LaLonde and Daniel Sullivan (1992). 'Earnings Losses of Displaced Workers.' American Economic Review 83(4): 685-709.

Kahn, Lisa (2005). 'The Long-Term Labor Market Consequences of Graduating College in a Bad Economy.' Mimeo, Harvard University.

Katz, Lawrence F. and David H. Autor (1999). 'Changes in the Wage Structure and Earnings Inequality.' In: Ashenfelter, Orley and David Card (eds), Handbook of Labor Economics. Elsevier Science Publishing Company Amsterdam, New York, and Oxford.

Katz, Lawrence F., Gary W. Loveman and David G. Blanchflower (1995). 'A Comparison of Changes in the Structure of Wages in Four OECD Countries.' In: Freeman, R. and L. Katz (eds), Differences and Changes in the Wage Structure.

Keith, Kristen and Abigail McWilliams (1999). 'The Returns to Job Mobility and Search by Gender.' Industrial and Labor Relations Review 52 (3): 460-477.

Kletzer, Lori G. and Robert W. Fairlie (2003). 'The Long-Term Costs of Job Displacement Among Young Workers.' Industrial Labor Relations Review 56(4): 682-698.

Koenker, R. and K. Hallock (2001). 'Quantile Regression.' Journal of Economic Perspectives 51 (4): 143-156. 
Krashinsky, Harry (2002). 'Evidence on Adverse Selection and Establishment Size In the Labor Market.' Industrial and Labor Relations Review 56(1): 84-96.

Krueger, Alan and Lawrence Summers (1988). 'Efficiency Wages and the Inter-Industry Wage Structure.' Econometrica 56 (2): 259-293.

Krause, Michael U. and Thomas A. Lubik (2005). 'The Cyclical Upgrading of Labor and On-the-Job Search.' Working Paper.

Krusell, Per and Anthony Smith (1999). 'On the welfare effects of eliminating business cycles.' Review of Economic Dynamics 2 (1): 245-272.

Lemieux, Thomas (1998). 'Estimating the Effects of Unions on Wage Inequality in a Panel Data Model with Comparative Advantage and Non-Random Selection.' Journal of Labor Economics 16 (April) 261-291.

Lucas, Robert (1987). Models of Business Cycles. Oxford: Basil Blackwell.

Macleod, Bentley and James M. Malcomson (1993). 'Investments, Holdup, and the Form of Market Contracts.' American Economic Review 83(4): 811-37.

Malcomson, James M. (1999). 'Individual Employment Contracts.' In: Ashenfelter, Orley and David Card (eds), Handbook of Labor Economics, Volume 3. Elsevier Science Publishing Company Amsterdam, New York, and Oxford.

Manning, Alan. Monopsony in Motion: Imperfect Competition in Labor Markets. Princeton: Princeton University Press (2002)

McCall, Brian (1990). 'Occupational Matching: A Test of Sorts.' Journal of Political Economy 98 (1): 45-69.

McDonald, Ian M. and Robort M. Solow (1985). 'Wages and Employment in a Segmented Labor Market.' The Quarterly Journal of Economics 100(4): 1115-1141.

McDonald, James Ted and Christopher Worswick (1999). 'Wages, Implicit Contracts, and the Business Cycle: Evidence from Canadian Micro Data.' The Journal of Policital Economy 107(4): 884-892.

McLaughlin, Kenneth J. and Mark J. Bils (2001). 'Inter-Industry Mobility and the Cyclical Upgrading of Labor' Journal of Labor Economics 19(1): 94-135.

Mincer, J., Schooling, Experience, and Earnings. Cambridge, MA: National Bureau of Economic Research, (1974)

Murphy, Kevin M. and Finis Welch (1990). 'Empirical Age-Earnings Profiles.' Journal of Labor Economics 8(2): 202-229.

Neal, Derek (1995). 'Industry-Specific Human Capital: Evidence From Displaced Workers,' Journal of Labor Economics, October, vol. 13: 653-77.

Neal, Derek (1998). 'The Link between Ability and Specialization: An Explanation for Observed Correlations between Wages and Mobility Rates.' The Journal of Human Resources 33 (1): 173-200.

Neal, Derek (1999). 'The Complexity of Job Mobility Among Young Men.' Journal of Labor Economics 17 (2): 237-261.

Neumark, David (2002). 'Youth Labor Markets in the U.S.: Shopping Around vs. Staying Put.' Review of Economics and Statistics (August) 462-48.

Oi, Walter Y. and Todd L. Idson (1999). 'Firm Size and Wages.' In: O. Ashenfelter and D. Card (eds.) Handbook of labor economics. Volume 3B. Amsterdam, New York, and Oxford: Elsevier Science.

Okun, Arthur M. (1973). 'Upward Mobility in a High-Pressure Economy.' Brookings Papers of Economic Activity 1: 207-52.

Oyer, Paul (2005). 'The Macro-Foundations of Microeconomics: Initial Labor Market Conditions and LongTerm Outcomes for Economists.' Mimeo, Stanford University. 
Parent, Daniel (2000). 'Industry-Specific Capital and the Wage Profile: Evidence from the National Longitudinal Survey of Youth and the Panel Study of Income Dynamics.' Journal of Labor Economics 18 (2): 306-323.

Prendergast, Canice (1993). 'The Role of Promotion in Human Capital Acquisition.' Quarterly Journal of Economics 108 (2).

Prendergast, Canice (1999). 'The Provision of Incentives in Firms.' Journal of Economic Literature 37 (1): 7-63.

Reder, M. W. (1955). 'The Theory of Occupational Wage Differentials.' American Economic Review 45 (5) 833 852.

Reynolds, Lloyd (1951). The Structure of Labor Markets. Westport, CN: Greenwood Press.

Rosen, Sherwin (1972). 'Learning and Experience in the Labor Market.' Journal of Human Resources 7(3).

Ryan, Paul (2001). 'The School-To-Work Transition: A Cross-National Perspective.' Journal of Economic Literature 39 (March): 34-92.

Shimer, Robert (2005a). 'The Cyclical Behavior of Equilibrium Unemployment and Vacancies.' The American Economic Review 95 (1): 25-49.

Shimer, Robert (2005b). 'Reassessing the Ins and Outs of Unemployment.' Working Paper.

Shimer, Robert (2005c). 'The Cyclicality of Hires, Separations, and Job-to-Job Transitions.' Federal Reserve Bank of St. Louis Review 87 (4): 493-507.

Solon, Gary, Robert Barsky, and Jonathan A. Parker (1994). 'Measuring the Cyclicality of Real Wages: How Important is Composition Bias?' The Quarterly Journal of Economics 109(1): 1-25.

Storesletten, Kjetil, Chris Telmer, and Amir Yaron (2001). 'The welfare cost of business cycles revisited: Finite lives and cyclical variation in idiosyncratic risk.' European Economic Review 45 (7): 1311-1339.

Topel, Robert and Michael Ward (1992). 'Job Mobility and the Careers of Young Men.' Quarterly Journal of Economics 107(2): 439-479.

von Wachter, Till and Stefan Bender (2005) 'At the Right Place at the Wrong Time: The Role of Firms and Luck in Young Workers' Careers.' Columbia University (forthcoming American Economic Review).

Vroman, Wayne (1977). 'Worker Upgrading and the Business Cycle.' Brookings Papers on Ecomonic Activity (1): 229-252.

Waggoner, Abigail (2004). 'Making their Own Luck: Educational Differences in the Migration Responses of Young Workers to Local Labor Market Conditions.' Harvard, mimeo.

Welch, Finis (1979). 'The Effect of Cohort Size on Earnings: The Baby Boom Babies' Financial Bust.' Journal of Political Economy 87 (5), Part 2: Education and Income Distribution, S65-S97. 
Figure 1: Experience-Profiles in Earnings, Mobility, and Firm Charachteristics Canada and U.S.

Panel A: Change in Annual Earnings

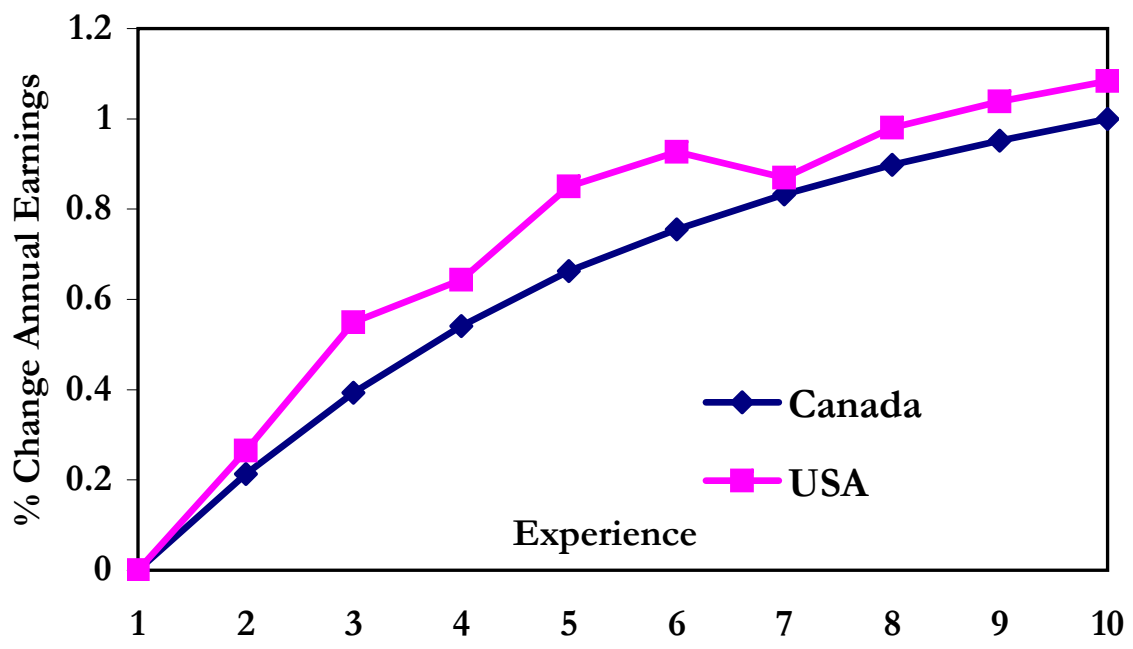

Panel C: Change in Firm Size

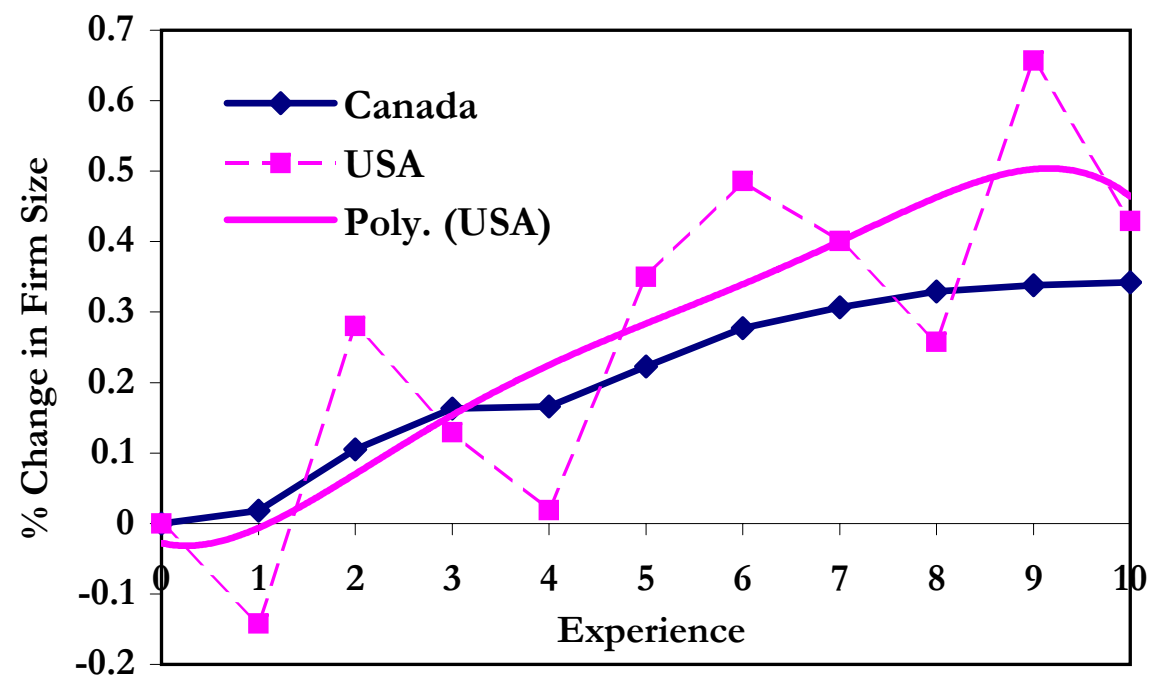

Panel B: Fraction Job Change

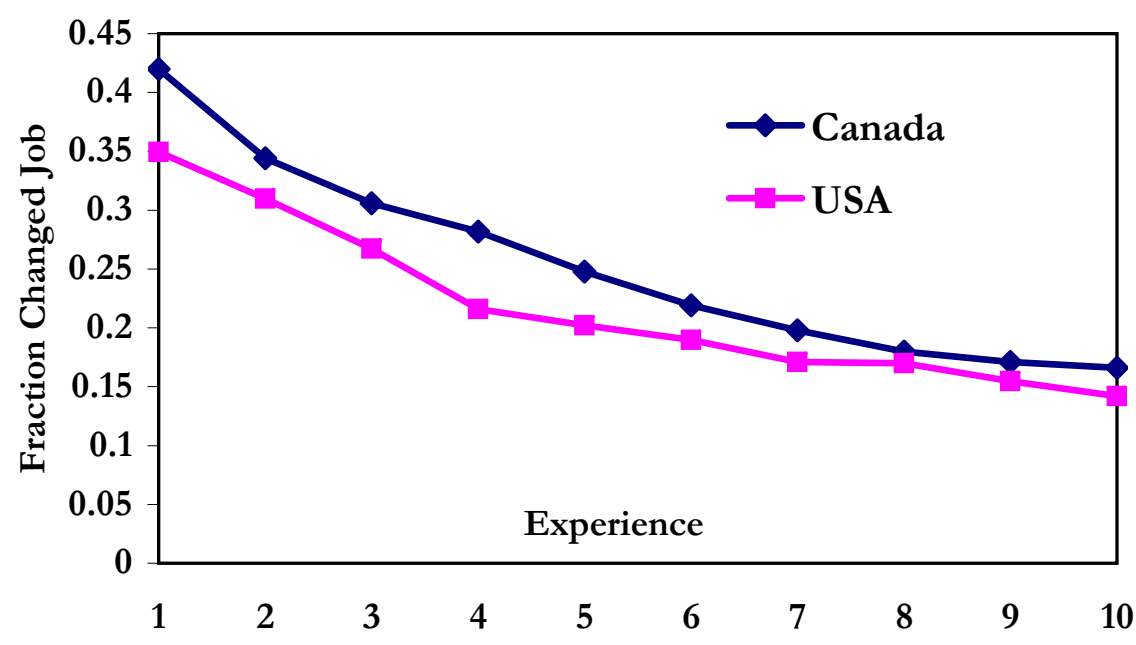

Panel D: Labor Force Attachment

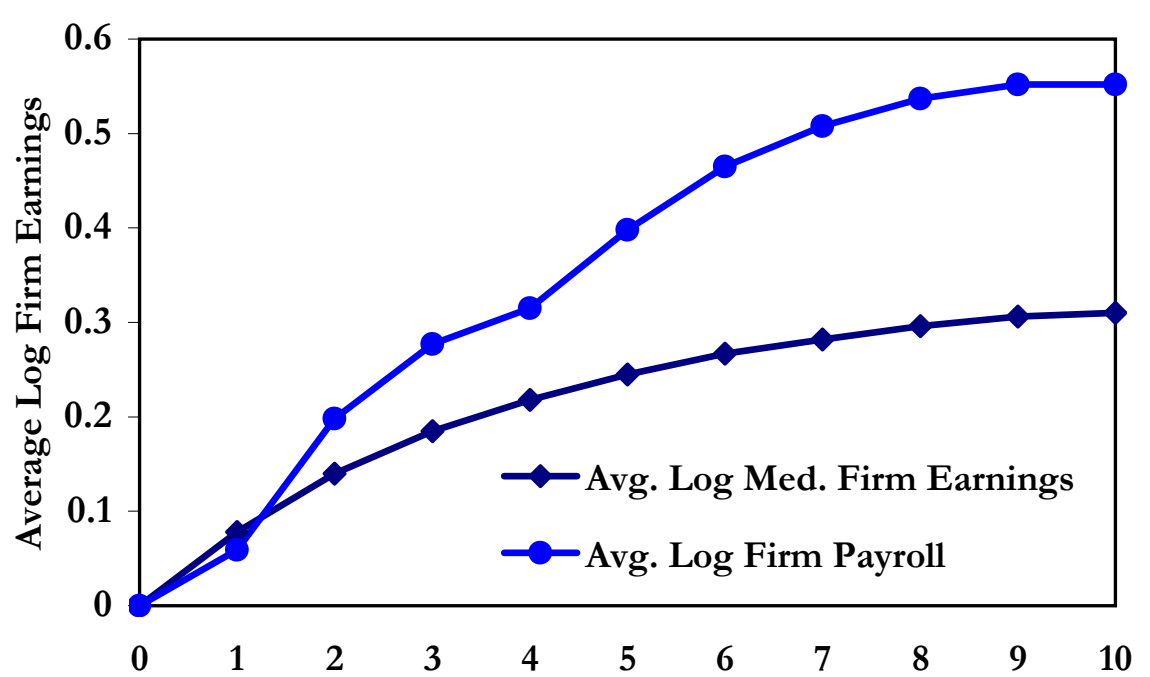


Figure 2A: Unemployment Rates Ages 14-24 for Canada and Provinces 1976-2000

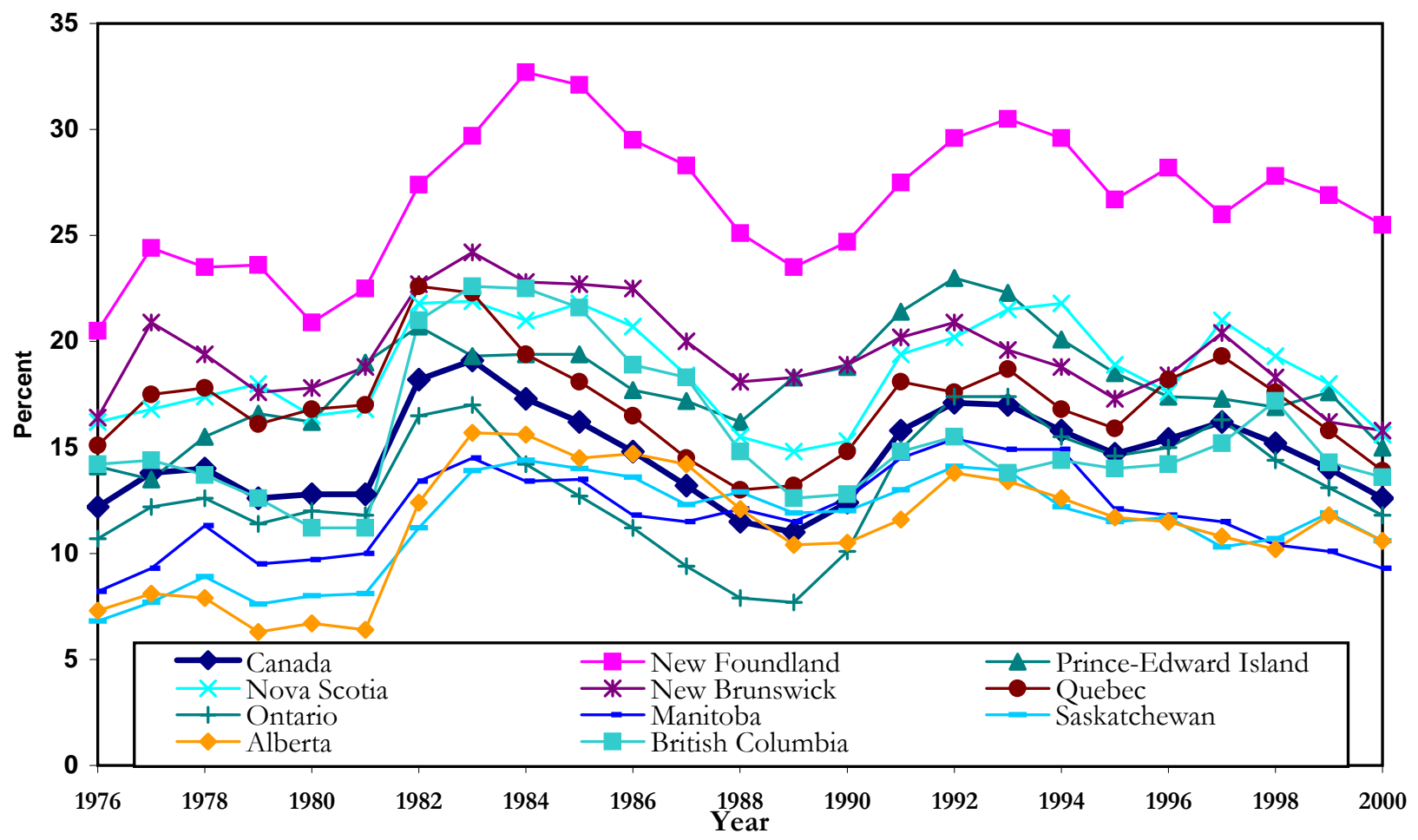

Figure 2B: Mature and Entry Level Earnings and Experience Profiles by Graduation Year

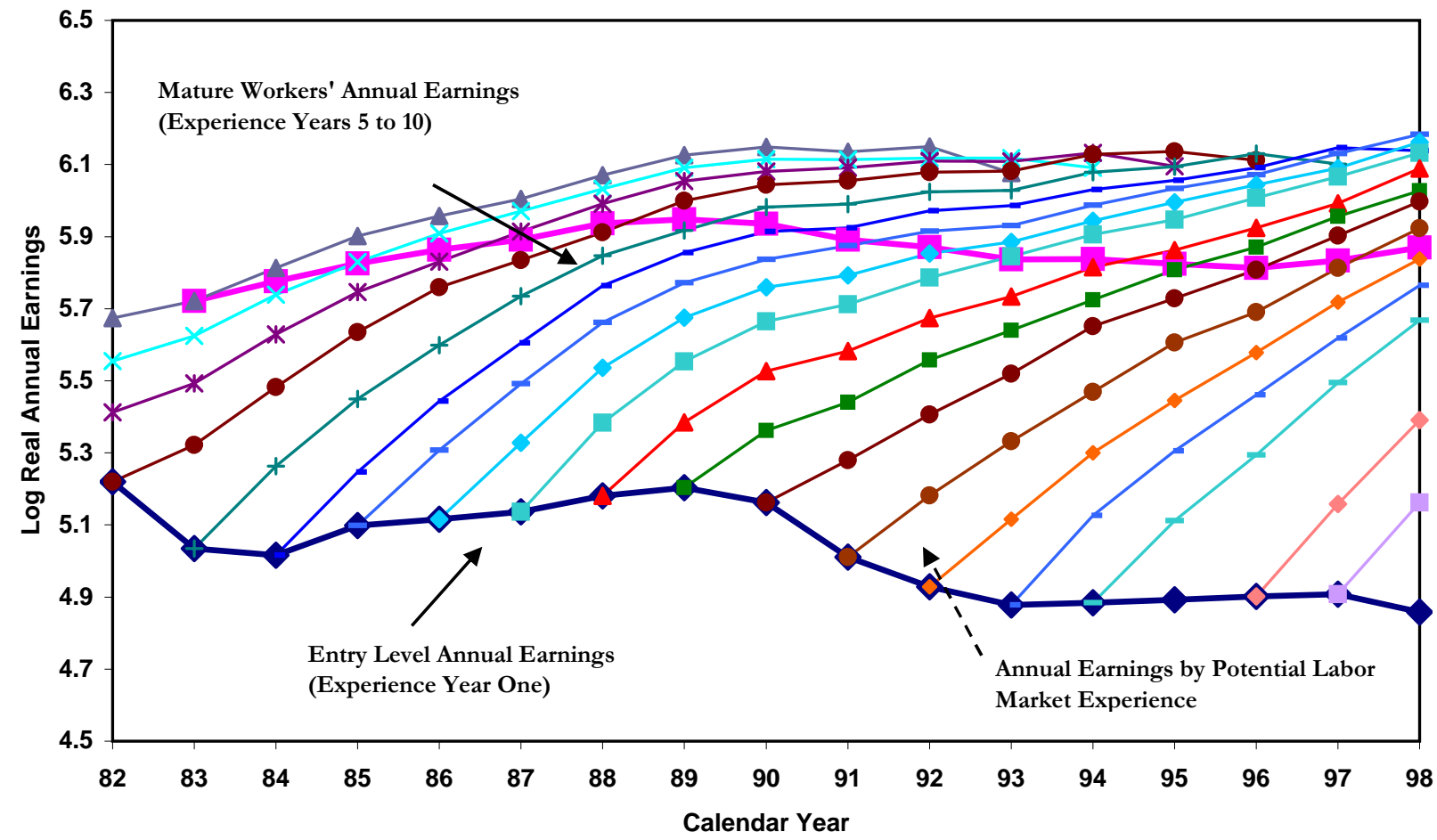


Figure 3A: Earnings By Experience Year For Cohorts Entering Labor Market 1978 to 1993

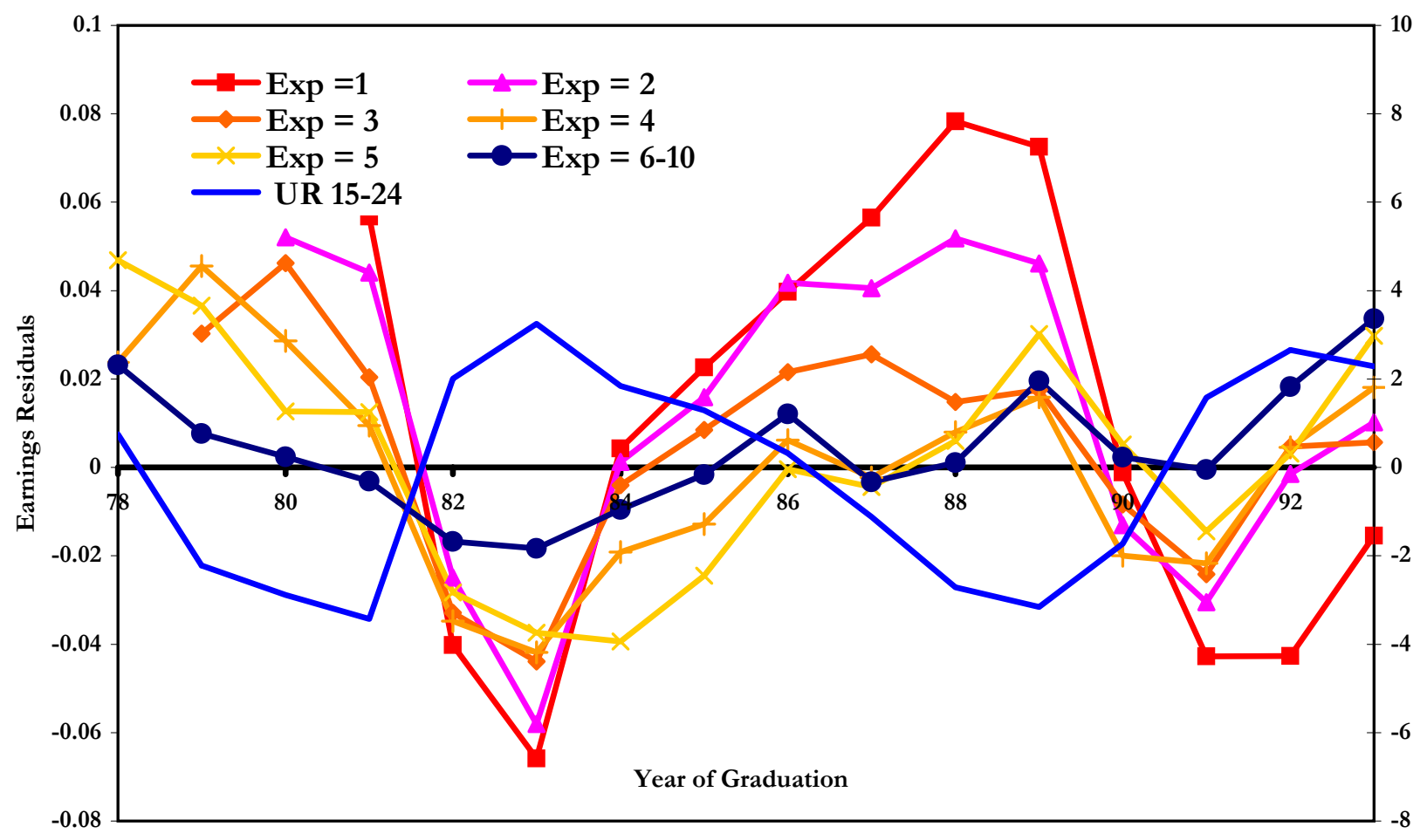

Figure 3B: Aggregate Unemployment and Wage Fluctuations by Experience-Level

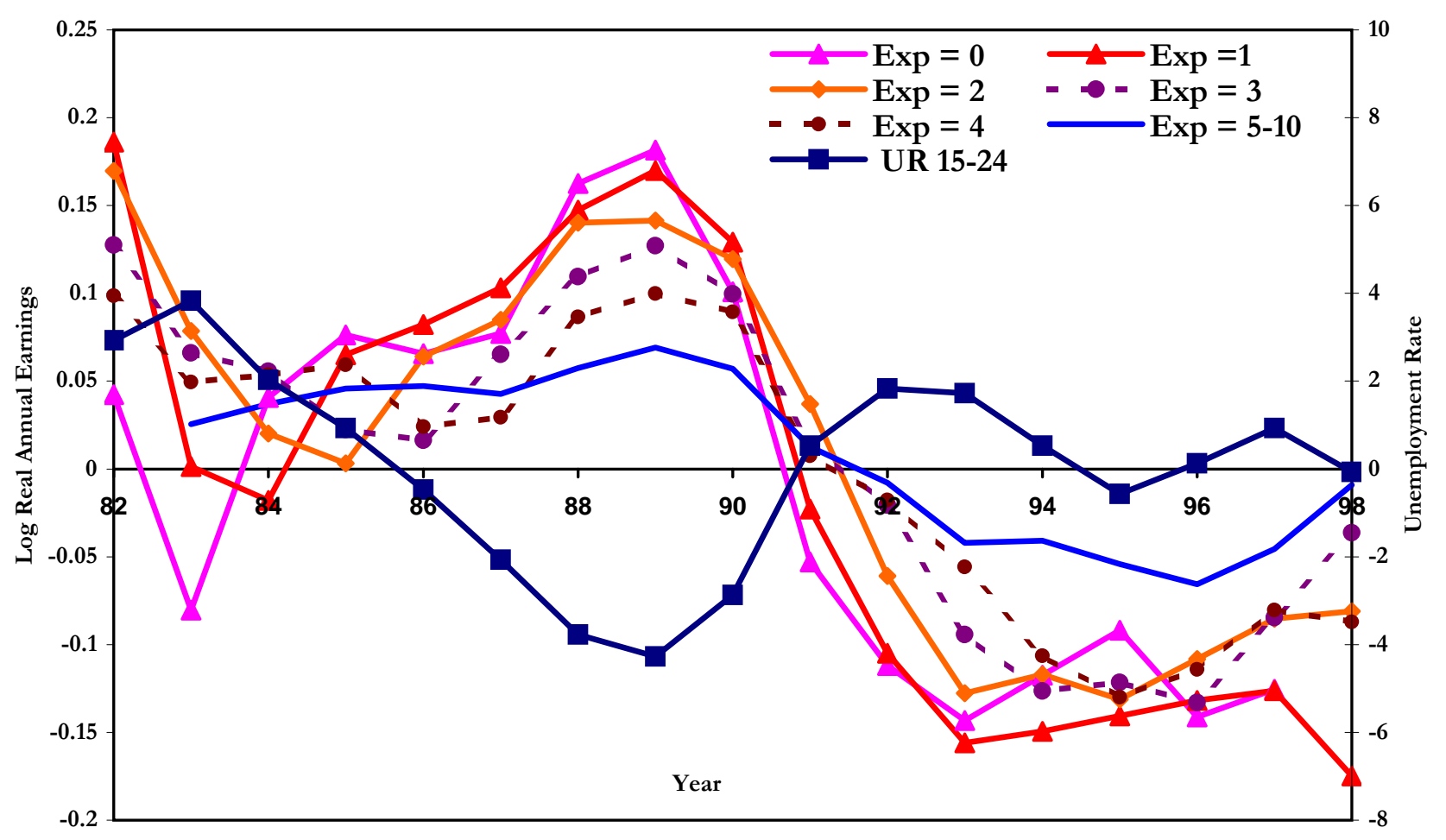


Table 1: Effect of Unemployment Rate at time of Graduation on Log Real Earnings by Potential Experience

\begin{tabular}{|c|c|c|c|c|c|c|}
\hline \multirow[b]{2}{*}{ National/Regional } & \multicolumn{6}{|c|}{ Specification } \\
\hline & National & National & Regional & National & National & Regional \\
\hline Trend & Linear & Quadratic & NA & Linear & Quadratic & NA \\
\hline \multirow[t]{2}{*}{$\mathrm{D}>=0$ ? } & No & No & No & Yes & Yes & Yes \\
\hline & (1) & (2) & (3) & (4) & (5) & (6) \\
\hline \multicolumn{7}{|l|}{ Experience Year } \\
\hline \multirow[t]{2}{*}{0} & -0.021 & -0.0224 & -0.0168 & -0.0231 & -0.0232 & -0.0187 \\
\hline & {$[0.0047]^{* * *}$} & {$[0.0039]^{* * *}$} & {$[0.0026]^{* * *}$} & {$[0.0037]^{* * *}$} & {$[0.0036]^{* * *}$} & {$[0.0024]^{* * *}$} \\
\hline \multirow[t]{2}{*}{1} & -0.0177 & -0.0187 & -0.0194 & -0.0168 & -0.0169 & -0.0181 \\
\hline & {$[0.0052]^{* * *}$} & {$[0.0028]^{* * *}$} & {$[0.0024]^{* * *}$} & {$[0.0049]^{* * *}$} & {$[0.0026]^{* * *}$} & {$[0.0021]^{* * *}$} \\
\hline \multirow[t]{2}{*}{2} & -0.0128 & -0.0137 & -0.0166 & -0.0116 & -0.012 & -0.0154 \\
\hline & {$[0.0033]^{* * *}$} & {$[0.0026]^{* * *}$} & {$[0.0022]^{* * *}$} & {$[0.0030]^{* * *}$} & {$[0.0021]^{* * *}$} & {$[0.0019]^{* * *}$} \\
\hline \multirow[t]{2}{*}{3} & -0.0084 & -0.0089 & -0.012 & -0.006 & -0.0066 & -0.0117 \\
\hline & {$[0.0022]^{* * *}$} & {$[0.0022]^{* * *}$} & {$[0.0021]^{* * *}$} & {$[0.0022]^{* *}$} & {$[0.0015]^{* * *}$} & {$[0.0017]^{* * *}$} \\
\hline \multirow[t]{2}{*}{4} & -0.0061 & -0.006 & -0.0093 & -0.0036 & -0.004 & -0.0096 \\
\hline & {$[0.0025]^{* *}$} & {$[0.0027]^{* *}$} & {$[0.0020]^{* * *}$} & {$[0.0028]$} & {$[0.0021]^{*}$} & {$[0.0016]^{* * *}$} \\
\hline \multirow[t]{2}{*}{5} & -0.0065 & -0.0055 & -0.0072 & -0.0035 & -0.0032 & -0.0081 \\
\hline & {$[0.0029]^{* *}$} & {$[0.0020]^{* *}$} & {$[0.0019]^{* * *}$} & [0.0024] & {$[0.0015]^{* *}$} & {$[0.0016]^{* * *}$} \\
\hline \multirow[t]{2}{*}{6} & -0.0027 & -0.0023 & -0.0062 & -0.0018 & -0.0012 & -0.0071 \\
\hline & [0.0032] & {$[0.0020]$} & {$[0.0020]^{* * *}$} & [0.0027] & [0.0018] & {$[0.0017]^{* * *}$} \\
\hline \multirow[t]{2}{*}{7} & -0.003 & -0.0027 & -0.0061 & -0.0019 & -0.001 & -0.0071 \\
\hline & {$[0.0043]$} & {$[0.0023]$} & {$[0.0020]^{* * *}$} & {$[0.0034]$} & [0.0018] & {$[0.0017]^{* * *}$} \\
\hline \multirow[t]{2}{*}{8} & -0.0001 & 0.0002 & -0.0043 & -0.0008 & 0.0006 & -0.0061 \\
\hline & [0.0049] & [0.0028] & {$[0.0019]^{* *}$} & {$[0.0034]$} & [0.0016] & {$[0.0017]^{* * *}$} \\
\hline \multirow[t]{2}{*}{9} & 0.0035 & 0.0038 & -0.0035 & 0.0021 & 0.0038 & -0.0051 \\
\hline & [0.0047] & [0.0027] & {$[0.0019]^{*}$} & [0.0033] & {$[0.0017]^{* *}$} & {$[0.0017]^{* * *}$} \\
\hline \multirow[t]{2}{*}{10} & 0.0066 & 0.0051 & -0.0015 & 0.0047 & 0.0049 & -0.0032 \\
\hline & [0.0048] & {$[0.0028]^{*}$} & {$[0.0020]$} & [0.0034] & {$[0.0022]^{* *}$} & {$[0.0017]^{*}$} \\
\hline \multirow[t]{2}{*}{ Constant } & 7.3951 & -3.6341 & 8.8017 & 7.673 & -2.0294 & 9.0456 \\
\hline & {$[0.2571]^{* * *}$} & [2.3916] & {$[0.1012]^{* * *}$} & {$[0.2095]^{* * *}$} & {$[0.8040]^{* *}$} & {$[0.0668]^{* * *}$} \\
\hline $\mathbf{N}$ & 14407 & 14407 & 14407 & 8679 & 8679 & 8679 \\
\hline R-squared & 0.76 & 0.77 & 0.8 & 0.93 & 0.93 & 0.95 \\
\hline
\end{tabular}

Note: The sample includes males in Canada leaving university between 1976 and 1995. 'D' indicates the difference between the actual year left and the predicted year of graduation based on year of entry and program. Sample sizes reflect cell sample sizes after collapsing the micro data by graduation cohort, province of residence in each year of graduation, and experience year. The national model regresses log annual earnings on the youth unemployment rate in the country at the year of college exit, interacted with experience years 0 to 10 , plus province of residence fixed effects, experience fixed effects, and a linear or quadratic graduation cohort trend. The regional model regresses log annual earnings on the youth unemployment rate in the province of first residence, interacted with experience years 0 to 10 , plus province of residence fixed effects, experience fixed effects, and year of graduation fixed effects. The coefficients shown are the unemployment rate at college exit and experience interactions. One, two, and three asterix indicates statistical significance at the 10 percent, 5 percent, and 1 percent levels respectively. See text for more details. 
Figure 4: The Persistent Effects of Unemployment in the Year of Graduation on Earnings, Job Mobility, and Firm Outcomes (Graduation Cohorts 1976-1995)

Panel A: Log Real Annual Earnings

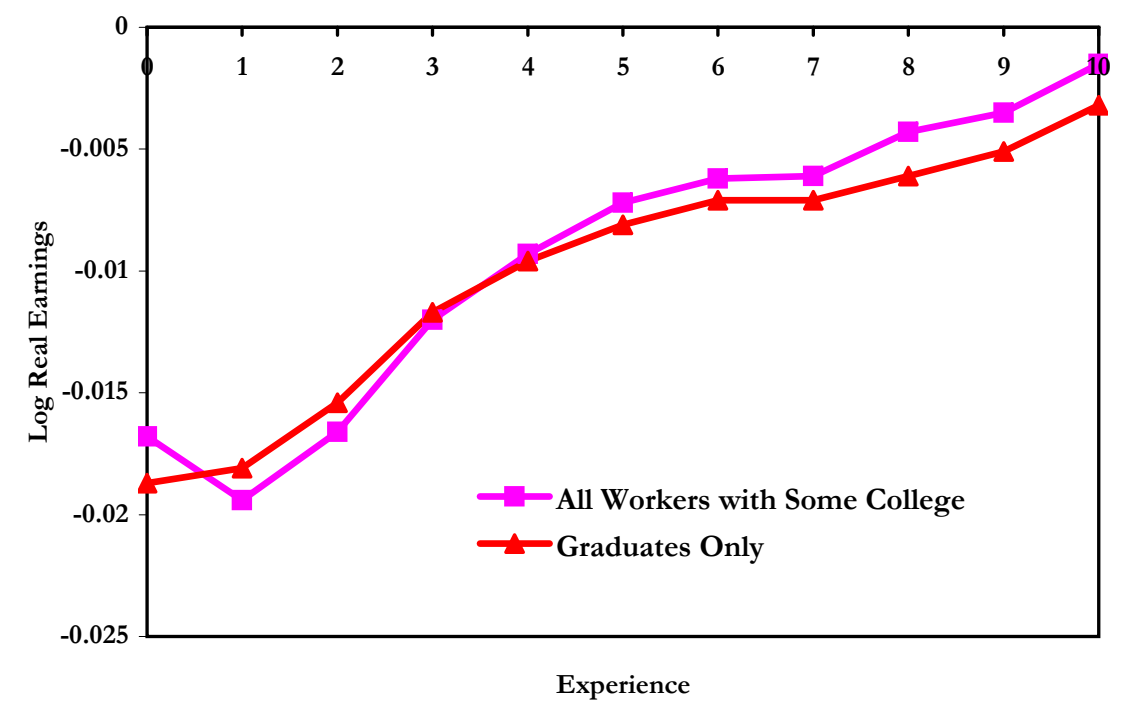

Panel C: Average Firm 'Quality', Graduates Only

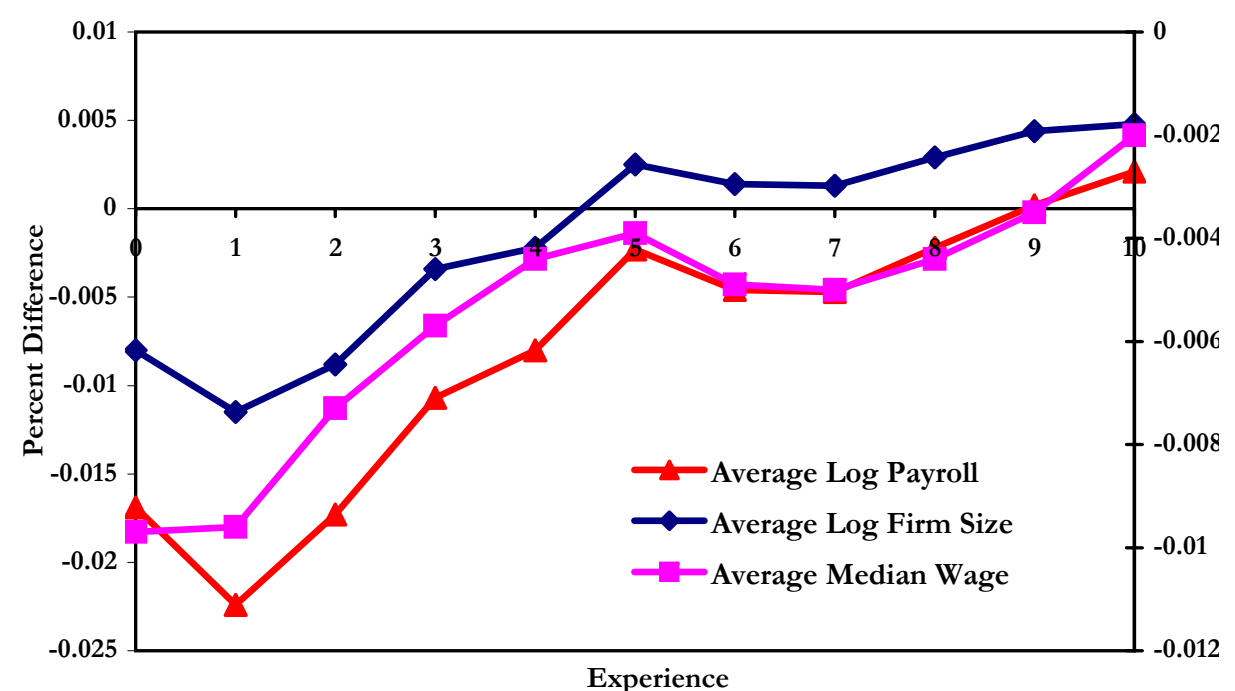

Panel B: Probability of Annual Change in Employers

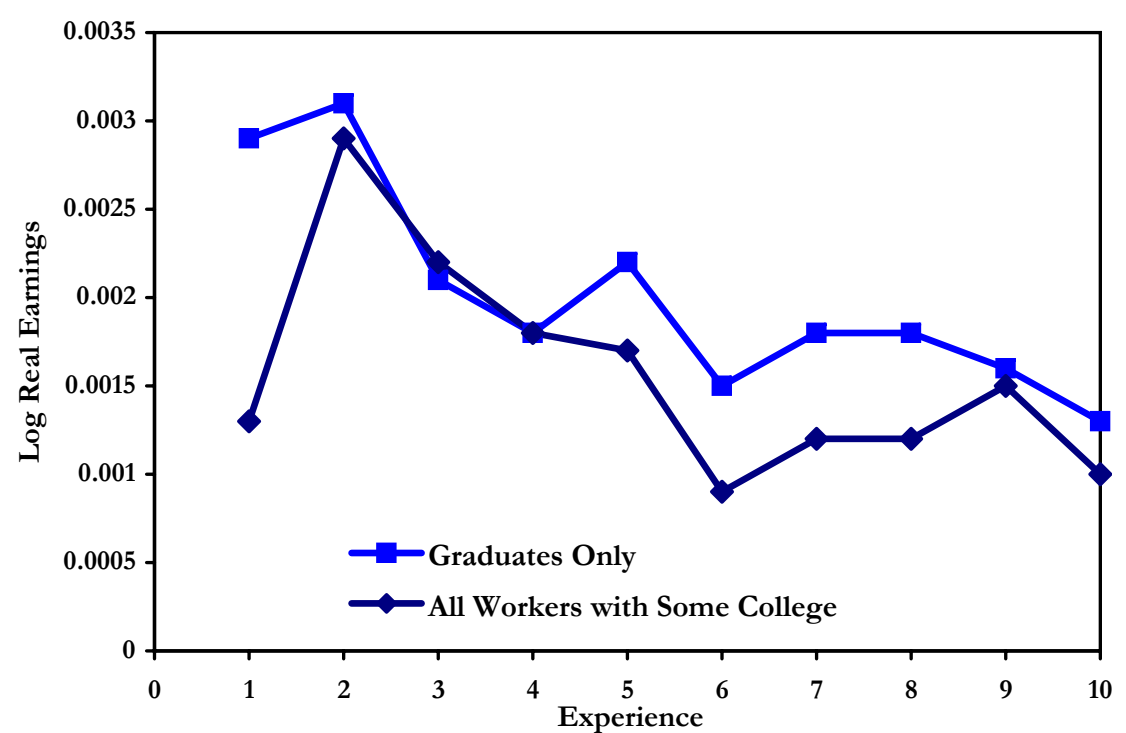

Panel D: Fraction not Working, Different Measures

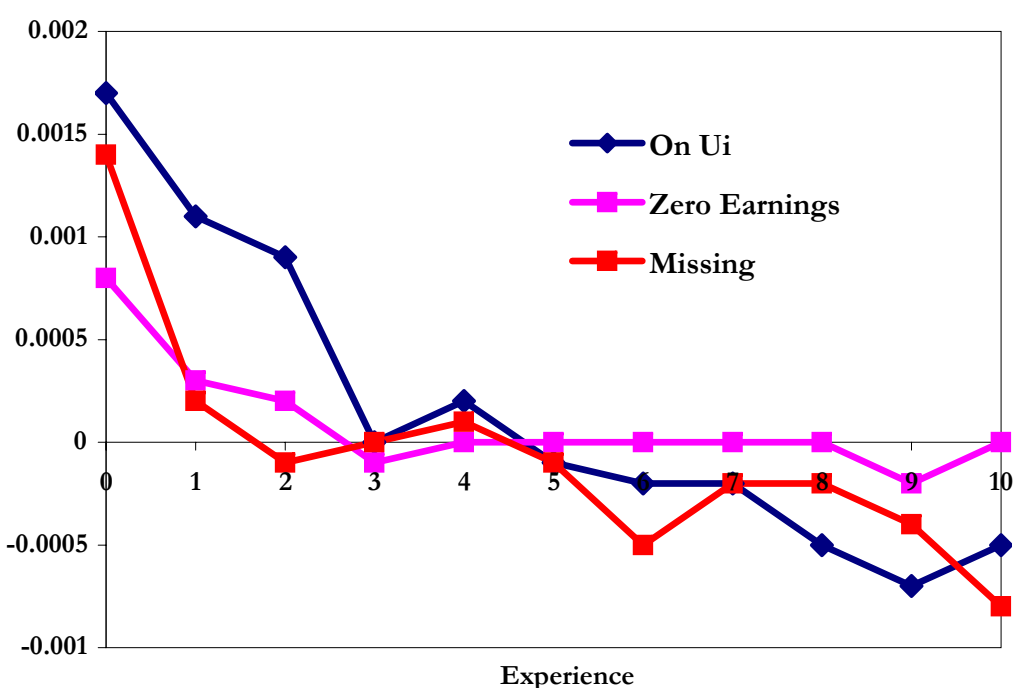


Table 2: Effect of Unemployment Rate at time of Graduation With Controls for UR History, Basic and Grouped Model - Graduate Sample, Regional Model, Cohorts 19821995

\begin{tabular}{|c|c|c|c|c|c|c|c|}
\hline \multirow{3}{*}{ Model } & \multicolumn{7}{|c|}{ Specification } \\
\hline & $\begin{array}{l}\text { Baseline } \\
\text { (No UR } \\
\text { History) }\end{array}$ & $\begin{array}{c}\text { With } \\
\text { Current } \\
\text { UR*Exp }\end{array}$ & $\begin{array}{l}\text { With } \\
\text { History in } \\
\text { Exp=1,2,3 }\end{array}$ & $\begin{array}{c}\text { With Full } \\
\text { UR } \\
\text { History }\end{array}$ & $\begin{array}{l}\text { Baseline } \\
\text { Group 0-1 } \\
\text { (No Hist.) }\end{array}$ & $\begin{array}{c}\text { Group } 01 \\
\text { With Full } \\
\text { History }\end{array}$ & $\begin{array}{c}\text { Group } 23 \\
\text { With Full } \\
\text { History }\end{array}$ \\
\hline & (1) & (2) & (3) & (4) & (5) & (6) & (7) \\
\hline \multicolumn{8}{|c|}{ Experience Year } \\
\hline 0 & $\begin{array}{c}-0.0174 \\
{[0.0028]^{* * *}}\end{array}$ & $\begin{array}{c}-0.0184 \\
{[0.0028]^{* * *}}\end{array}$ & $\begin{array}{c}-0.0173 \\
{[0.0027]^{* * *}}\end{array}$ & $\begin{array}{c}-0.0159 \\
{[0.0028]^{* * *}}\end{array}$ & $\begin{array}{c}-0.0165 \\
{[0.0030]^{* * *}}\end{array}$ & $\begin{array}{c}-0.0147 \\
{[0.0031]^{* * *}}\end{array}$ & $\begin{array}{l}--- \\
---\end{array}$ \\
\hline 1 & $\begin{array}{c}-0.0176 \\
{[0.0024]^{* * *}}\end{array}$ & $\begin{array}{c}-0.0178 \\
{[0.0047]^{* * *}}\end{array}$ & $\begin{array}{c}-0.017 \\
{[0.0044]^{* * *}}\end{array}$ & $\begin{array}{c}-0.0172 \\
{[0.0048]^{* * *}}\end{array}$ & $\begin{array}{c}-0.0177 \\
{[0.0025]^{* * *}}\end{array}$ & $\begin{array}{c}-0.016 \\
{[0.0026]^{* * *}}\end{array}$ & $\begin{array}{l}--- \\
---\end{array}$ \\
\hline 2 & $\begin{array}{c}-0.016 \\
{[0.0021]^{* * *}}\end{array}$ & $\begin{array}{c}-0.0142 \\
{[0.0025]^{* * *}}\end{array}$ & $\begin{array}{c}-0.014 \\
{[0.0041]^{* * *}}\end{array}$ & $\begin{array}{c}-0.0121 \\
{[0.0041]^{* * *}}\end{array}$ & $\begin{array}{c}-0.0167 \\
{[0.0020]^{* * *}}\end{array}$ & $\begin{array}{c}-0.0141 \\
{[0.0025]^{* * *}}\end{array}$ & $\begin{array}{l}-0.0026 \\
{[0.0025]}\end{array}$ \\
\hline 3 & $\begin{array}{c}-0.0128 \\
{[0.0019]^{* * *}}\end{array}$ & $\begin{array}{c}-0.0117 \\
{[0.0020]^{* * *}}\end{array}$ & $\begin{array}{c}-0.0087 \\
{[0.0037]^{* *}}\end{array}$ & $\begin{array}{c}-0.0094 \\
{[0.0035]^{* * *}}\end{array}$ & $\begin{array}{c}-0.0134 \\
{[0.0018]^{* * *}}\end{array}$ & $\begin{array}{c}-0.0107 \\
{[0.0024]^{* * *}}\end{array}$ & $\begin{array}{c}-0.004 \\
{[0.0024]^{*}}\end{array}$ \\
\hline 4 & $\begin{array}{c}-0.0117 \\
{[0.0018]^{* * *}}\end{array}$ & $\begin{array}{c}-0.0113 \\
{[0.0019]^{* * *}}\end{array}$ & $\begin{array}{l}-0.0063 \\
{[0.0039]}\end{array}$ & $\begin{array}{c}-0.008 \\
{[0.0038]^{* *}}\end{array}$ & $\begin{array}{c}-0.0122 \\
{[0.0018]^{* * *}}\end{array}$ & $\begin{array}{c}-0.0102 \\
{[0.0024]^{* * *}}\end{array}$ & $\begin{array}{l}-0.0036 \\
{[0.0030]}\end{array}$ \\
\hline 5 & $\begin{array}{c}-0.011 \\
{[0.0018]^{* * *}}\end{array}$ & $\begin{array}{c}-0.0108 \\
{[0.0018]^{* * *}}\end{array}$ & $\begin{array}{l}-0.0076 \\
{[0.0046]}\end{array}$ & $\begin{array}{c}-0.0082 \\
{[0.0043]^{*}}\end{array}$ & $\begin{array}{c}-0.0113 \\
{[0.0016]^{* * *}}\end{array}$ & $\begin{array}{c}-0.0095 \\
{[0.0026]^{* * *}}\end{array}$ & $\begin{array}{l}-0.0026 \\
{[0.0041]}\end{array}$ \\
\hline 6 & $\begin{array}{c}-0.0104 \\
{[0.0019]^{* * *}}\end{array}$ & $\begin{array}{c}-0.0102 \\
{[0.0019]^{* * *}}\end{array}$ & $\begin{array}{c}-0.008 \\
{[0.0055]}\end{array}$ & $\begin{array}{l}-0.0076 \\
{[0.0048]}\end{array}$ & $\begin{array}{c}-0.0109 \\
{[0.0018]^{* * *}}\end{array}$ & $\begin{array}{c}-0.0065 \\
{[0.0030]^{* *}}\end{array}$ & $\begin{array}{l}-0.0071 \\
{[0.0043]}\end{array}$ \\
\hline 7 & $\begin{array}{c}-0.0105 \\
{[0.0019]^{* * *}}\end{array}$ & $\begin{array}{c}-0.0105 \\
{[0.0019]^{* * *}}\end{array}$ & $\begin{array}{c}-0.0104 \\
{[0.0049]^{* *}}\end{array}$ & $\begin{array}{c}-0.0099 \\
{[0.0046]^{* *}}\end{array}$ & $\begin{array}{c}-0.0108 \\
{[0.0019]^{* * *}}\end{array}$ & $\begin{array}{c}-0.0072 \\
{[0.0032]^{* *}}\end{array}$ & $\begin{array}{l}-0.0044 \\
{[0.0041]}\end{array}$ \\
\hline 8 & $\begin{array}{c}-0.0095 \\
{[0.0019]^{* * *}}\end{array}$ & $\begin{array}{c}-0.0095 \\
{[0.0019]^{* * *}}\end{array}$ & $\begin{array}{l}-0.0067 \\
{[0.0050]}\end{array}$ & $\begin{array}{l}-0.0049 \\
{[0.0043]}\end{array}$ & $\begin{array}{c}-0.0099 \\
{[0.0020]^{* * *}}\end{array}$ & $\begin{array}{c}-0.0066 \\
{[0.0029]^{* *}}\end{array}$ & $\begin{array}{c}-0.0024 \\
{[0.0040]}\end{array}$ \\
\hline 9 & $\begin{array}{c}-0.0086 \\
{[0.0019]^{* * *}}\end{array}$ & $\begin{array}{c}-0.0085 \\
{[0.0019]^{* * *}}\end{array}$ & $\begin{array}{c}-0.0103 \\
{[0.0051]^{* *}}\end{array}$ & $\begin{array}{c}-0.0091 \\
{[0.0038]^{* *}}\end{array}$ & $\begin{array}{c}-0.009 \\
{[0.0020]^{* * *}}\end{array}$ & $\begin{array}{c}-0.0054 \\
{[0.0032]^{*}}\end{array}$ & $\begin{array}{l}-0.0029 \\
{[0.0045]}\end{array}$ \\
\hline 10 & $\begin{array}{c}-0.006 \\
{[0.0021]^{* * *}}\end{array}$ & $\begin{array}{c}-0.0054 \\
{[0.0021]^{* * *}}\end{array}$ & $\begin{array}{c}-0.0125 \\
{[0.0055]^{* *}}\end{array}$ & $\begin{array}{c}-0.0115 \\
{[0.0050]^{* *}}\end{array}$ & $\begin{array}{c}-0.0062 \\
{[0.0023]^{* * *}}\end{array}$ & $\begin{array}{l}-0.0021 \\
{[0.0039]}\end{array}$ & $\begin{array}{l}-0.0032 \\
{[0.0051]}\end{array}$ \\
\hline Constant & $\begin{array}{c}9.2257 \\
{[0.0982]^{* * *}}\end{array}$ & $\begin{array}{c}9.2636 \\
{[0.1023]^{* * *}}\end{array}$ & $\begin{array}{c}9.2633 \\
{[0.0969]^{* * *}}\end{array}$ & $\begin{array}{c}9.2379 \\
{[0.1034]^{* * *}}\end{array}$ & $\begin{array}{c}9.2195 \\
{[0.1040]^{* * *}}\end{array}$ & $\begin{array}{c}9.2031 \\
{[0.1102]^{* * *}}\end{array}$ & --- \\
\hline $\mathbf{N}$ & 7536 & 7536 & 7536 & 6994 & 7536 & 7299 & --- \\
\hline $\mathbf{R}^{2}$ & 0.96 & 0.96 & 0.96 & 0.97 & 0.96 & 0.96 & --- \\
\hline
\end{tabular}

Note: The sample includes males in Canada graduating university (with $\mathrm{D}>=0$ ) between 1982 and 1995 . Sample sizes reflect cell sample sizes after collapsing the micro data by graduation cohort, province of residence in each year of graduation, and experience year. The national model regresses log annual earnings on the youth unemployment rate in the country, instrumented with the youth unemployment rate in the province of first residence (the columns indicate whether this rate is averaged over the first 1 to 3 years), interacted with experience years 0 to 10 , plus province of residence fixed effects, experience fixed effects, and year of graduation fixed effects. The columns indicate additional controls for experience interacted with later unemployment rates. One, two, and three asterix indicates statistical significance at the 10 percent, 5 percent, and 1 percent levels respectively. See text for more details. 
Figure 5: Selected Results from Sensitivity Analysis (Effect of Further Unemployment Shocks, Selective Graduation, Selective Participation, Cohort Differences)

Panel A: Effect of Unemployment Rate at Time of Graduation on Earnings Controlling for Dynamic Effects of Further Unemployment Shocks (by Experience Groups)

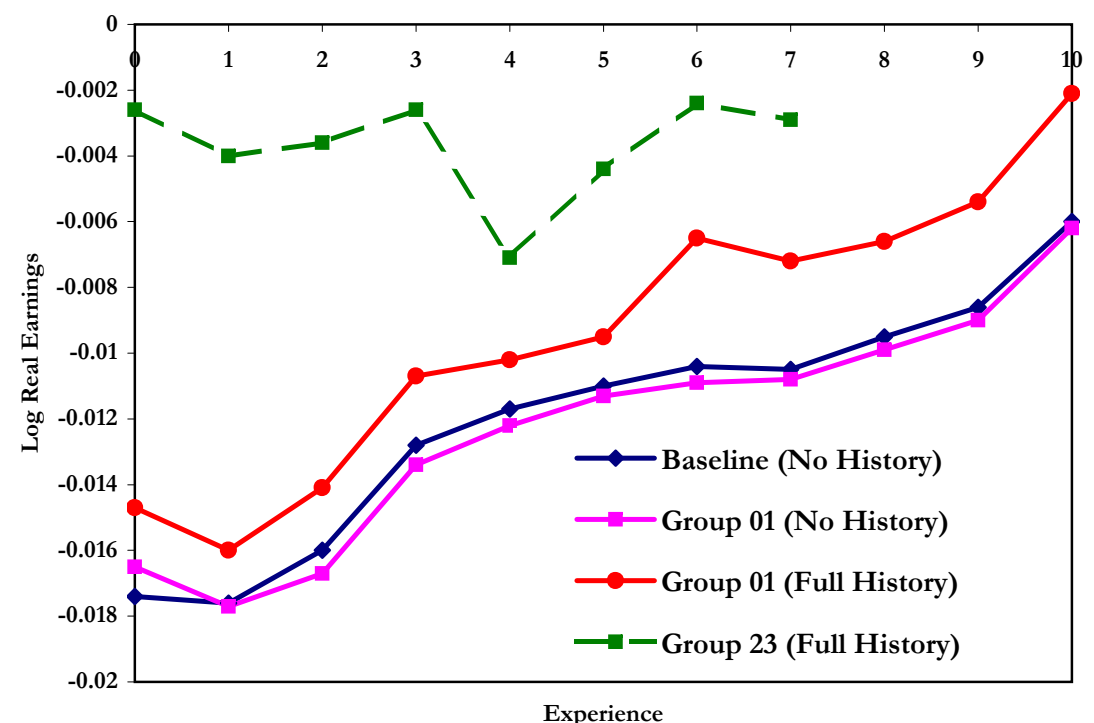

Panel C: Effect of Unemployment Rate at Time of Graduation for Workers with Positive Earnings Each Period

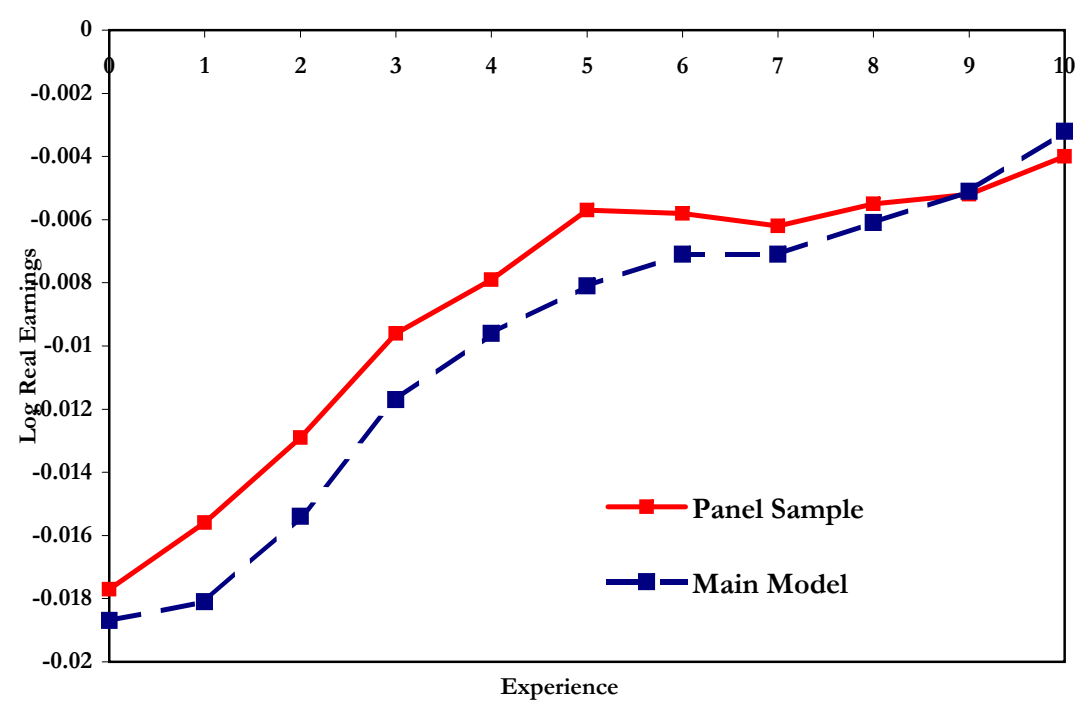

Panel B: Effect of Unemployment Rate at Time of Graduation Instrumenting with Unemployment at Time of Predicted Graduation

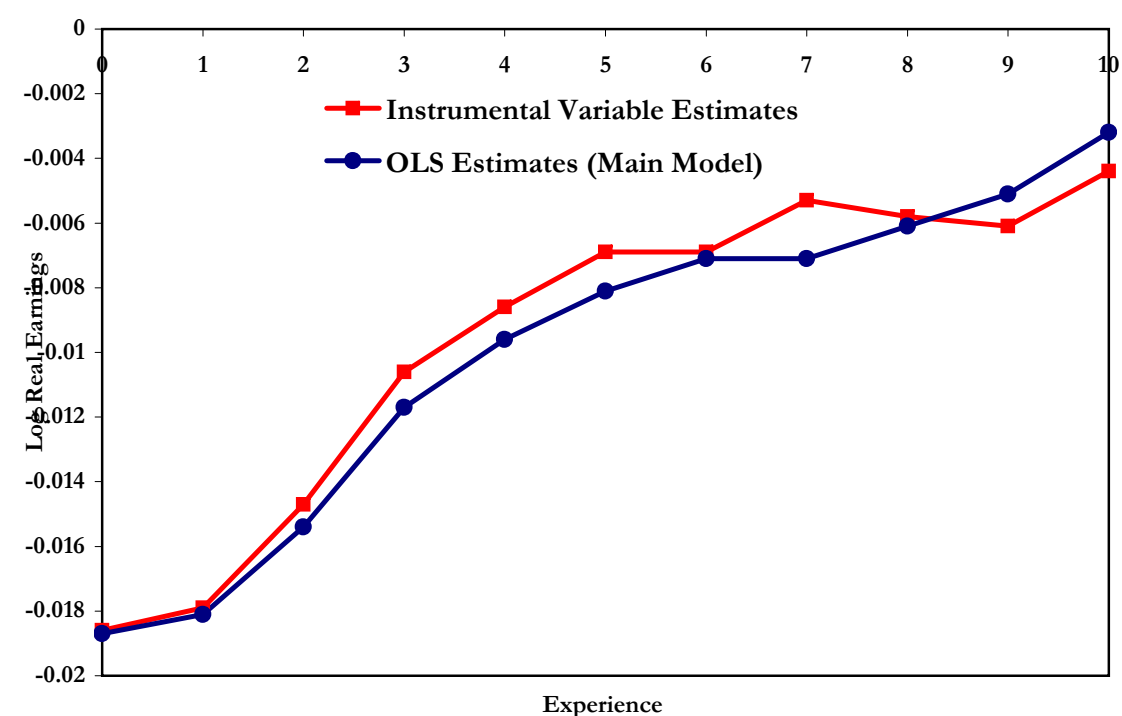

Experience Groups of Graduation Cohorts

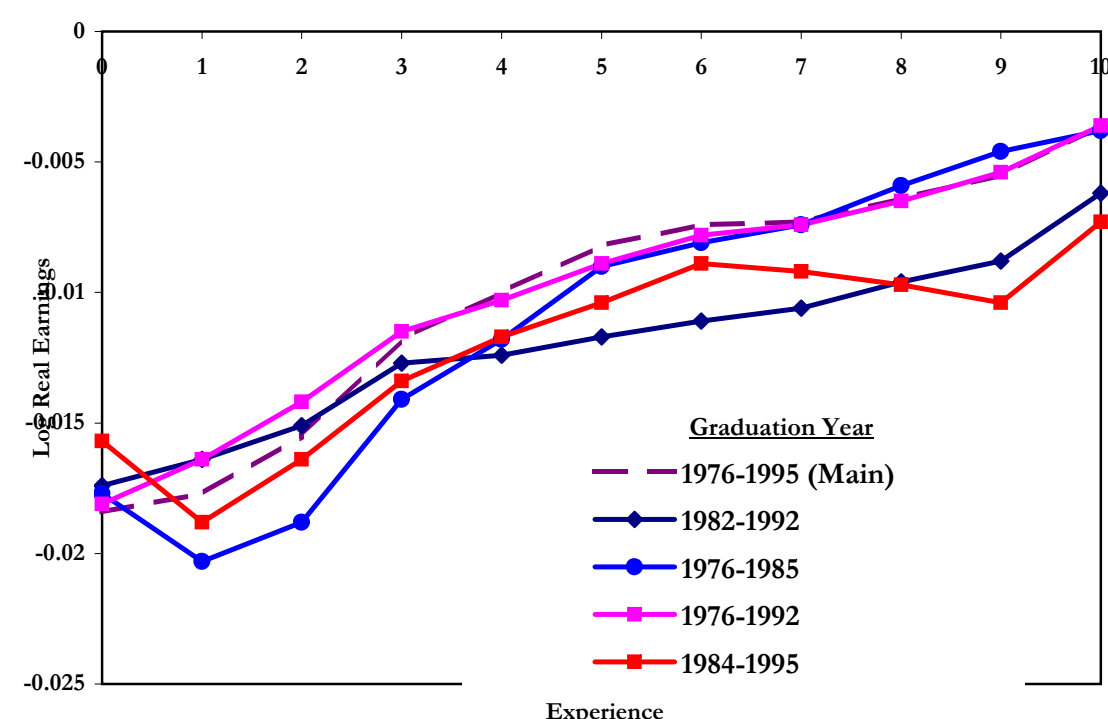


Table 3: Effect of Unemployment Rate at time of Graduation on Labor Force Participation - and Province Mobility - Graduate Sample

Specification

Nat./Reg.

Regional

National

Outcome

\begin{tabular}{ccc}
\hline Fraction & Fraction & Fraction on \\
Zero & Not in & UI \\
Earnings & Sample & \\
\hline
\end{tabular}

\begin{tabular}{ll}
\multicolumn{2}{c}{ National } \\
\hline Fraction & Fraction \\
Changed & Left First \\
Province & Province
\end{tabular}

\begin{tabular}{ll}
\multicolumn{2}{c}{ Regional } \\
\hline Fraction & Fraction \\
Changed & Left First \\
Province & Province
\end{tabular}

(1)

(2)

(3)

(4)

(5)

(6)

(7)

\section{Experience Year}

\begin{tabular}{|c|c|c|c|c|c|c|c|}
\hline \multirow[t]{2}{*}{0} & 0.0008 & 0.0014 & 0.0017 & & & - & - \\
\hline & {$[0.0001]^{* * *}$} & {$[0.0005]^{* * *}$} & {$[0.0003]^{* * *}$} & & & - & - \\
\hline \multirow[t]{2}{*}{1} & 0.0003 & 0.0002 & 0.0011 & 0 & 0.0007 & 0.0023 & 0.001 \\
\hline & {$[0.0001]^{* * *}$} & [0.0003] & {$[0.0002]^{* * *}$} & [0.0003] & [0.0005] & {$[0.0004]^{* * *}$} & [0.0010] \\
\hline \multirow[t]{2}{*}{2} & 0.0002 & -0.0001 & 0.0009 & 0.0001 & 0.0003 & 0.0014 & 0.0029 \\
\hline & {$[0.0001]^{* *}$} & [0.0003] & {$[0.0002]^{* * *}$} & [0.0002] & [0.0006] & {$[0.0002]^{* * *}$} & {$[0.0008]^{* * *}$} \\
\hline \multirow[t]{2}{*}{3} & -0.0001 & 0 & 0 & 0 & -0.0001 & 0.0008 & 0.0036 \\
\hline & [0.0001] & [0.0003] & [0.0002] & [0.0002] & {$[0.0005]$} & {$[0.0002]^{* * *}$} & {$[0.0008]^{* * *}$} \\
\hline \multirow[t]{2}{*}{4} & 0 & 0.0001 & 0.0002 & 0 & -0.0005 & 0.0001 & 0.0039 \\
\hline & [0.0001] & [0.0002] & [0.0001] & [0.0002] & {$[0.0005]$} & [0.0002] & {$[0.0008]^{* * *}$} \\
\hline \multirow[t]{2}{*}{5} & 0 & -0.0001 & -0.0001 & -0.0001 & -0.0007 & -0.0003 & 0.0038 \\
\hline & {$[0.0001]$} & [0.0003] & [0.0002] & {$[0.0002]$} & [0.0006] & {$[0.0002]$} & {$[0.0008]^{* * *}$} \\
\hline \multirow[t]{2}{*}{6} & 0 & -0.0005 & -0.0002 & 0.0002 & -0.0005 & -0.0004 & 0.0036 \\
\hline & [0.0001] & {$[0.0003]^{*}$} & [0.0002] & [0.0002] & [0.0006] & {$[0.0002]^{*}$} & {$[0.0008]^{* * *}$} \\
\hline \multirow[t]{2}{*}{7} & 0 & -0.0002 & -0.0002 & -0.0003 & -0.0008 & -0.0008 & 0.0035 \\
\hline & [0.0001] & [0.0002] & [0.0002] & {$[0.0002]^{*}$} & {$[0.0005]$} & {$[0.0002]^{* * *}$} & {$[0.0008]^{* * *}$} \\
\hline \multirow[t]{2}{*}{8} & 0 & -0.0002 & -0.0005 & -0.0001 & -0.0003 & -0.0008 & 0.0034 \\
\hline & [0.0001] & [0.0003] & {$[0.0002]^{* * *}$} & [0.0003] & [0.0008] & {$[0.0003]^{* * *}$} & {$[0.0008]^{* * *}$} \\
\hline \multirow[t]{2}{*}{9} & -0.0002 & -0.0004 & -0.0007 & 0.0001 & -0.0003 & -0.0008 & 0.0031 \\
\hline & {$[0.0001]^{* * *}$} & {$[0.0002]^{*}$} & {$[0.0002]^{* * *}$} & [0.0002] & [0.0009] & {$[0.0003]^{* * *}$} & {$[0.0008]^{* * *}$} \\
\hline \multirow[t]{2}{*}{10} & 0 & -0.0008 & -0.0005 & 0 & -0.0005 & -0.0006 & 0.0031 \\
\hline & [0.0001] & {$[0.0003]^{* * *}$} & {$[0.0002]^{* * *}$} & [0.0002] & [0.0008] & {$[0.0003]^{* *}$} & {$[0.0009]^{* * *}$} \\
\hline \multirow[t]{2}{*}{ Constant } & -0.0032 & 0.0227 & 0.0162 & 0.006 & -0.0399 & 0.0227 & 0.0305 \\
\hline & [0.0025] & {$[0.0118]^{*}$} & {$[0.0072]^{* *}$} & [0.0097] & {$[0.0315]$} & {$[0.0068]^{* * *}$} & [0.0307] \\
\hline $\mathbf{N}$ & 8679 & 8679 & 8679 & 5909 & 5942 & 5909 & 5942 \\
\hline $\mathbf{R}^{2}$ & 0.2 & 0.39 & 0.34 & 0.08 & 0.14 & 0.4 & 0.71 \\
\hline
\end{tabular}

Note: Columns indicate outcome variable used as the dependent variable. Each model regresses these outcomes on the youth unemployment rate in the province of first residence, interacted with experience years 0 to 10 , plus province of residence fixed effects, experience fixed effects, and year of graduation fixed effects. The coefficients shown are the unemployment rate at college exit and experience interactions. One, two, and three asterix indicates statistical significance at the 10 percent, 5 percent, and 1 percent levels respectively. See text for more details. 
Table 4: Effect of Unemployment Rate at time of Graduation on Job and Industry Mobility and Average Employer Characteristics - Graduates Only

\begin{tabular}{|c|c|c|c|c|c|c|c|c|}
\hline \multirow{3}{*}{ Outcome } & \multicolumn{8}{|c|}{ Specification } \\
\hline & $\begin{array}{c}\text { Fraction } \\
\text { Changed } \\
\text { Firm }\end{array}$ & $\begin{array}{l}\text { Fraction } \\
\text { Changed } \\
\text { Industry }\end{array}$ & $\begin{array}{c}\text { Fraction } \\
\text { Left First } \\
\text { Firm }\end{array}$ & $\begin{array}{c}\text { Fraction } \\
\text { Left First } \\
\text { Industry }\end{array}$ & $\begin{array}{l}\text { Log Firm } \\
\text { Size }\end{array}$ & $\begin{array}{c}\text { Fraction } \\
\text { Firm Size } \\
>1000\end{array}$ & $\begin{array}{c}\text { Average } \\
\text { Median } \\
\text { Firm Wage }\end{array}$ & $\begin{array}{c}\text { Average } \\
\text { Log Firm } \\
\text { Payroll }\end{array}$ \\
\hline & (1) & (2) & (3) & (4) & (5) & (6) & (7) & (8) \\
\hline \multicolumn{9}{|c|}{ Experience Year } \\
\hline \multirow[t]{2}{*}{0} & - & - & - & - & -0.008 & -0.0016 & -0.0097 & -0.0169 \\
\hline & - & - & - & - & {$[0.0050]$} & {$[0.0008]^{*}$} & {$[0.0014]^{* * *}$} & {$[0.0058]^{* * *}$} \\
\hline \multirow[t]{2}{*}{1} & 0.0029 & 0.0021 & 0.0038 & 0.0025 & -0.0115 & -0.002 & -0.0096 & -0.0224 \\
\hline & {$[0.0008]^{* * *}$} & {$[0.0007]^{* * *}$} & {$[0.0010]^{* * *}$} & {$[0.0011]^{* *}$} & {$[0.0049]^{* *}$} & {$[0.0009]^{* *}$} & {$[0.0011]^{* * *}$} & {$[0.0055]^{* * *}$} \\
\hline \multirow[t]{2}{*}{2} & 0.0031 & 0.0034 & 0.0046 & 0.0041 & -0.0088 & -0.002 & -0.0073 & -0.0173 \\
\hline & {$[0.0007]^{* * *}$} & {$[0.0006]^{* * *}$} & {$[0.0011]^{* * *}$} & {$[0.0011]^{* * *}$} & {$[0.0050]^{*}$} & {$[0.0008]^{* *}$} & {$[0.0011]^{* * *}$} & {$[0.0056]^{* * *}$} \\
\hline \multirow[t]{2}{*}{3} & 0.0021 & 0.0023 & 0.0049 & 0.0045 & -0.0034 & -0.0012 & -0.0057 & -0.0107 \\
\hline & {$[0.0007]^{* * *}$} & {$[0.0006]^{* * *}$} & {$[0.0009]^{* * *}$} & {$[0.0009]^{* * *}$} & {$[0.0047]$} & {$[0.0008]$} & {$[0.0010]^{* * *}$} & {$[0.0052]^{* *}$} \\
\hline \multirow[t]{2}{*}{4} & 0.0018 & 0.0015 & 0.0052 & 0.0046 & -0.0022 & -0.0009 & -0.0044 & -0.008 \\
\hline & {$[0.0006]^{* * *}$} & {$[0.0006]^{* *}$} & {$[0.0009]^{* * *}$} & {$[0.0009]^{* * *}$} & {$[0.0048]$} & {$[0.0008]$} & {$[0.0011]^{* * *}$} & {$[0.0054]$} \\
\hline \multirow[t]{2}{*}{5} & 0.0022 & 0.0019 & 0.0043 & 0.0039 & 0.0025 & -0.0003 & -0.0039 & -0.0023 \\
\hline & {$[0.0005]^{* * *}$} & {$[0.0005]^{* * *}$} & {$[0.0010]^{* * *}$} & {$[0.0010]^{* * *}$} & [0.0051] & [0.0009] & {$[0.0012]^{* * *}$} & {$[0.0057]$} \\
\hline \multirow[t]{2}{*}{6} & 0.0015 & 0.0011 & 0.0043 & 0.004 & 0.0014 & -0.0005 & -0.0049 & -0.0046 \\
\hline & {$[0.0005]^{* * *}$} & {$[0.0005]^{* *}$} & {$[0.0010]^{* * *}$} & {$[0.0010]^{* * *}$} & {$[0.0050]$} & [0.0009] & {$[0.0012]^{* * *}$} & {$[0.0056]$} \\
\hline \multirow[t]{2}{*}{7} & 0.0018 & 0.002 & 0.0041 & 0.0039 & 0.0013 & -0.0007 & -0.005 & -0.0047 \\
\hline & {$[0.0006]^{* * *}$} & {$[0.0006]^{* * *}$} & {$[0.0011]^{* * *}$} & {$[0.0010]^{* * *}$} & [0.0054] & {$[0.0009]$} & {$[0.0012]^{* * *}$} & {$[0.0060]$} \\
\hline \multirow[t]{2}{*}{8} & 0.0018 & 0.002 & 0.0044 & 0.0042 & 0.0029 & -0.0003 & -0.0044 & -0.0022 \\
\hline & {$[0.0008]^{* *}$} & {$[0.0007]^{* * *}$} & {$[0.0011]^{* * *}$} & {$[0.0010]^{* * *}$} & [0.0054] & [0.0009] & {$[0.0011]^{* * *}$} & {$[0.0060]$} \\
\hline \multirow[t]{2}{*}{9} & 0.0016 & 0.002 & 0.0047 & 0.0052 & 0.0044 & 0.0001 & -0.0035 & 0.0002 \\
\hline & [0.0010] & {$[0.0009]^{* *}$} & {$[0.0010]^{* * *}$} & {$[0.0010]^{* * *}$} & [0.0055] & [0.0009] & {$[0.0011]^{* * *}$} & {$[0.0063]$} \\
\hline \multirow[t]{2}{*}{10} & 0.0013 & 0.0015 & 0.005 & 0.0055 & 0.0048 & 0.0002 & -0.002 & 0.0021 \\
\hline & [0.0011] & [0.0011] & {$[0.0010]^{* * *}$} & {$[0.0010]^{* * *}$} & {$[0.0068]$} & {$[0.0010]$} & [0.0015] & {$[0.0077]$} \\
\hline \multirow[t]{2}{*}{ Constant } & 0.3407 & 0.3151 & 0.1391 & 0.523 & 8.1745 & 0.719 & 0.8069 & 7.2971 \\
\hline & {$[0.0184]^{* * *}$} & {$[0.0187]^{* * *}$} & {$[0.0428]^{* * *}$} & {$[0.0403]^{* * *}$} & {$[0.1953]^{* * *}$} & {$[0.0283]^{* * *}$} & {$[0.0368]^{* * *}$} & {$[0.2203]^{* * *}$} \\
\hline $\mathbf{N}$ & 5871 & 5871 & 5863 & 5861 & 8435 & 8435 & 8435 & 8435 \\
\hline $\mathbf{R}^{2}$ & 0.8 & 0.79 & 0.86 & 0.77 & 0.53 & 0.47 & 0.75 & 0.6 \\
\hline
\end{tabular}

Note: Columns indicate the firm or industry mobility variable used as the dependent variable. Each model regresses these outcomes on the youth unemployment rate in the province of first residence, interacted with experience years 0 to 10 , plus province of residence fixed effects, experience fixed effects, and year of graduation fixed effects. The coefficients shown are the unemployment rate at college exit and experience interactions. One, two, and three asterix indicates statistical significance at the 10 percent, 5 percent, and 1 percent levels respectively. See text for more details. 
Table 5: Wage Growth for Stayers and Movers Between Firms, Industries, and Provinces -- Averages and Effects of Initial Unemployment Rate, Graduates Only

$\begin{array}{ccccccc}\text { Overall } & \text { Gains of } & \text { Gains of } & \text { Gains of } & \text { Gains of } & \text { Gains of } & \text { Gains of } \\ \text { Earnings } & \text { Job } & \text { Job } & \text { Industry } & \text { Industry } & \text { Province } & \text { Province } \\ \text { Growth } & \text { Movers } & \text { Stayers } & \text { Movers } & \text { Stayers } & \text { Movers } & \text { Stayers }\end{array}$
(1)
(2)
(3)
(4)
(5)
(6)
(7)

\begin{tabular}{|c|c|c|c|c|c|c|c|}
\hline \multirow{2}{*}{$\frac{\text { Experience Year }}{1}$} & \multicolumn{7}{|c|}{ Panel A: Average Wage Growth by Mover Status } \\
\hline & 0.47 & 0.49 & 0.46 & 0.46 & 0.46 & 0.56 & 0.47 \\
\hline 2 & 0.21 & 0.27 & 0.18 & 0.29 & 0.18 & 0.27 & 0.21 \\
\hline 3 & 0.18 & 0.25 & 0.15 & 0.28 & 0.15 & 0.24 & 0.18 \\
\hline 4 & 0.15 & 0.23 & 0.12 & 0.23 & 0.12 & 0.20 & 0.15 \\
\hline 5 & 0.12 & 0.19 & 0.10 & 0.22 & 0.10 & 0.15 & 0.12 \\
\hline 6 & 0.09 & 0.13 & 0.08 & 0.11 & 0.08 & 0.11 & 0.09 \\
\hline 7 & 0.08 & 0.12 & 0.07 & 0.10 & 0.07 & 0.10 & 0.08 \\
\hline 8 & 0.07 & 0.09 & 0.06 & 0.05 & 0.06 & 0.06 & 0.07 \\
\hline 9 & 0.06 & 0.08 & 0.06 & 0.05 & 0.06 & 0.08 & 0.06 \\
\hline 10 & 0.06 & 0.08 & 0.05 & 0.06 & 0.05 & 0.06 & 0.06 \\
\hline
\end{tabular}

Experience Year

Panel B: Effect of Unemployment Rate on Wage Growth by Mover Status

$\begin{array}{cccccccc}\mathbf{1} & -0.0004 & 0.001 & -0.002 & 0.006 & -0.002 & 0.011 & -0.001 \\ \mathbf{2} & \mathbf{0 . 0 0 6} & \mathbf{0 . 0 0 6} & \mathbf{0 . 0 0 5} & 0.007 & \mathbf{0 . 0 0 5} & 0.001 & \mathbf{0 . 0 0 6} \\ \mathbf{3} & \mathbf{0 . 0 0 7} & \mathbf{0 . 0 0 8} & \mathbf{0 . 0 0 6} & \mathbf{0 . 0 1 5} & \mathbf{0 . 0 0 6} & 0.005 & \mathbf{0 . 0 0 7} \\ \mathbf{4} & \mathbf{0 . 0 0 5} & \mathbf{0 . 0 0 6} & \mathbf{0 . 0 0 4} & -0.001 & \mathbf{0 . 0 0 4} & -0.010 & \mathbf{0 . 0 0 5} \\ \mathbf{5} & \mathbf{0 . 0 0 4} & \mathbf{0 . 0 0 7} & \mathbf{0 . 0 0 3} & 0.007 & \mathbf{0 . 0 0 3} & -0.005 & \mathbf{0 . 0 0 4} \\ \mathbf{6} & \mathbf{0 . 0 0 3} & \mathbf{0 . 0 0 5} & \mathbf{0 . 0 0 2} & 0.006 & \mathbf{0 . 0 0 2} & \mathbf{- 0 . 0 1 7} & \mathbf{0 . 0 0 3} \\ \mathbf{7} & \mathbf{0 . 0 0 2} & 0.002 & \mathbf{0 . 0 0 2} & 0.006 & \mathbf{0 . 0 0 2} & -0.002 & \mathbf{0 . 0 0 2} \\ \mathbf{8} & \mathbf{0 . 0 0 3} & \mathbf{0 . 0 0 4} & \mathbf{0 . 0 0 3} & 0.004 & \mathbf{0 . 0 0 3} & -0.004 & \mathbf{0 . 0 0 3} \\ \mathbf{9} & \mathbf{0 . 0 0 2} & -0.0002 & \mathbf{0 . 0 0 2} & -0.007 & \mathbf{0 . 0 0 2} & -0.008 & \mathbf{0 . 0 0 2} \\ \mathbf{1 0} & \mathbf{0 . 0 0 2} & 0.003 & \mathbf{0 . 0 0 2} & -0.002 & \mathbf{0 . 0 0 2} & -0.013 & \mathbf{0 . 0 0 3}\end{array}$

Note: Panel A contains simple averages of annual wage growth among males in Canada graduating university (with $\mathrm{D}>=0$ ) between 1976 and 1995. For Panel B, columns indicate selected sample for regression models of annual increases in log earnings on the youth unemployment rate in the province of first residence, interacted with experience years 0 to 10 , plus province of residence fixed effects, experience fixed effects, and year of graduation fixed effects. The coefficients shown are the unemployment rate at college exit and experience interactions. Bold (italicized) coefficients signify significance at the 1 (10) percent levels respectively. See text for more details. 
Figure 6A: Effect of Initial Unemployment Rate Controlling for First Firm and Industry Fixed Effects Interacted With Experience - Graduates Only

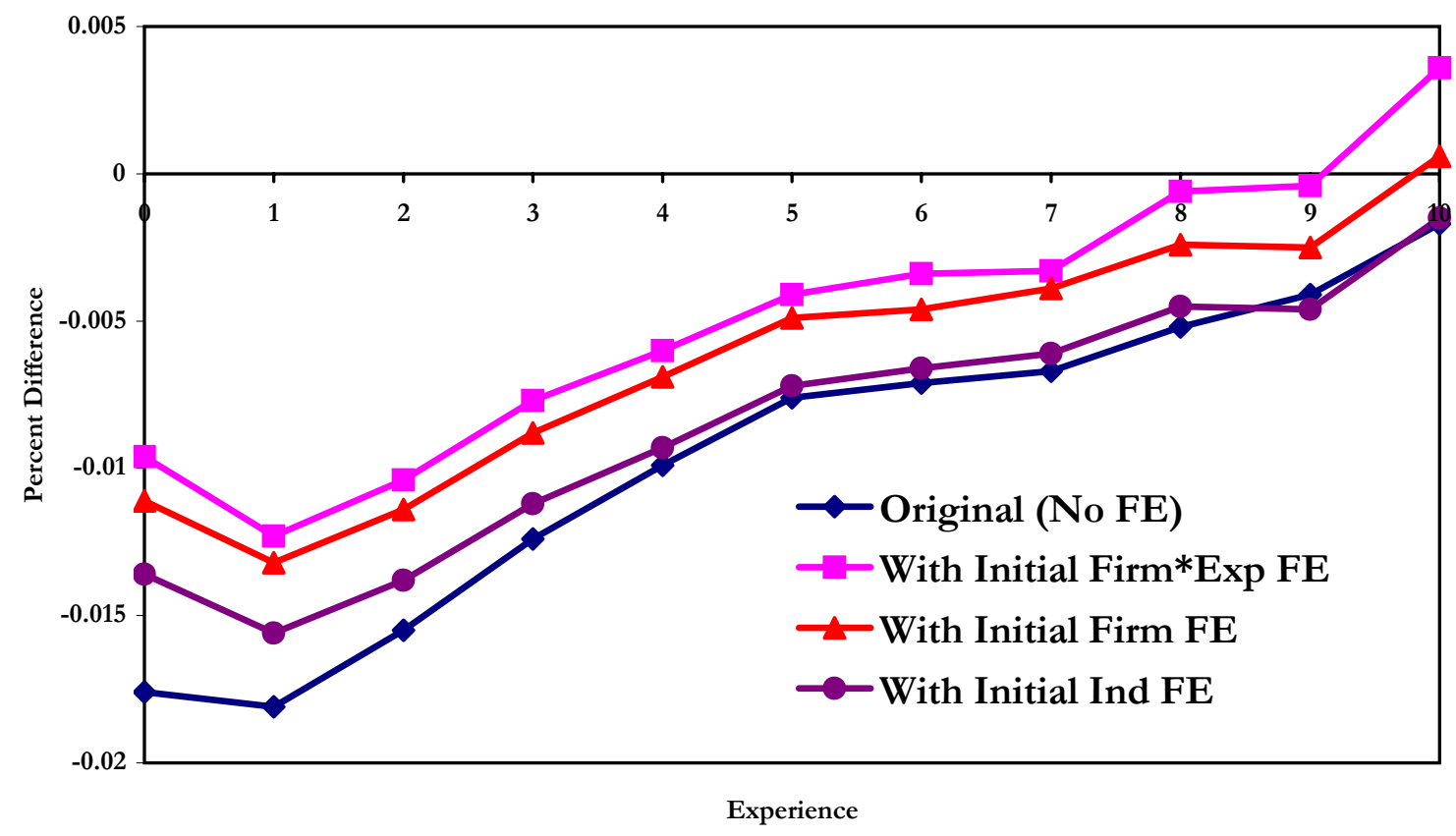

Figure 6B: Effect of Initial Unemployment Rate by Firm Type - Graduates Only

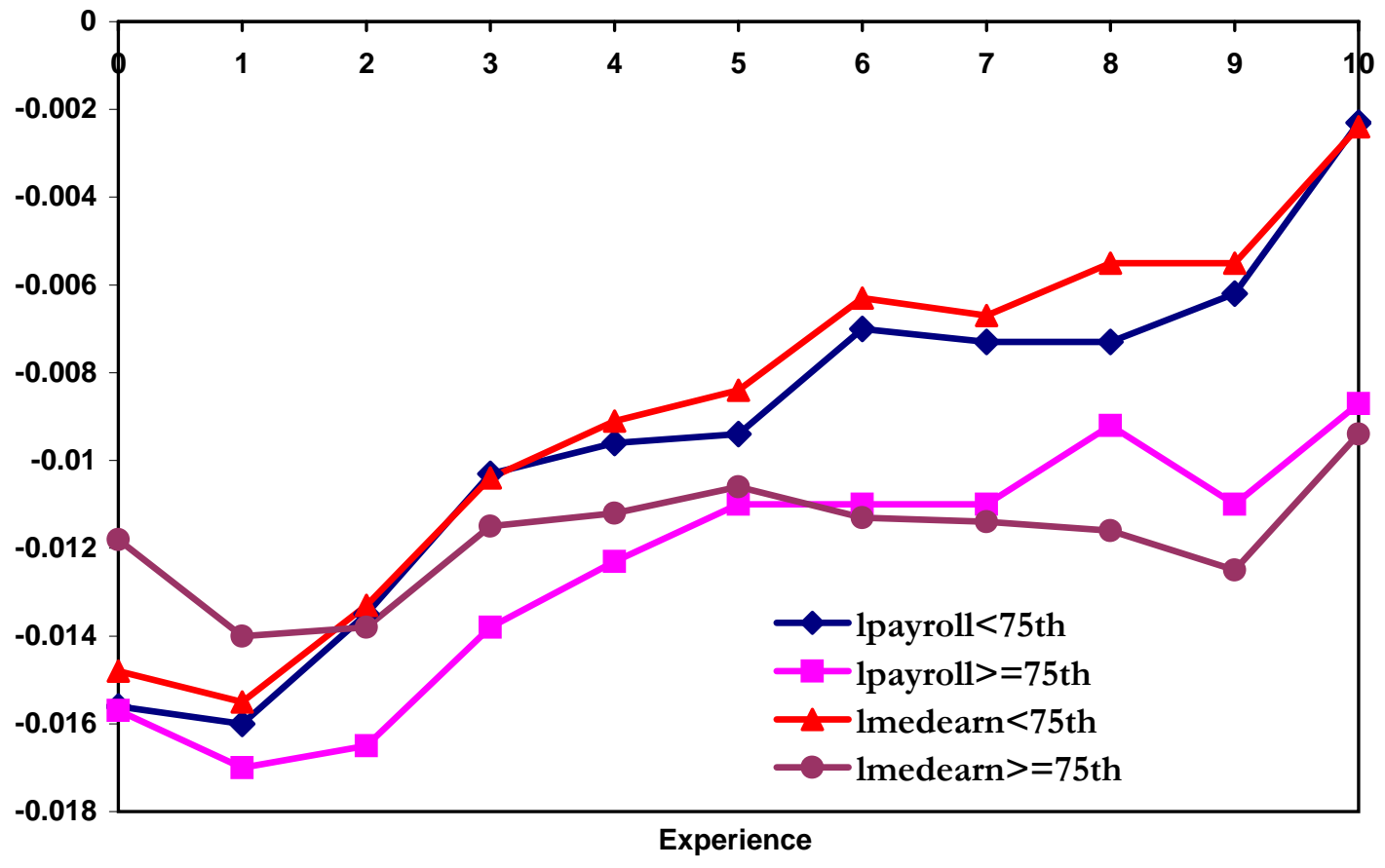


Table 6: Experience Gradient in Annual Earnings, Job Mobility, and Other Outcomes (Elasticities) - All Workers

\begin{tabular}{|c|c|c|c|c|c|c|c|c|}
\hline Outcome & $\begin{array}{l}\text { Annual } \\
\text { Earnings }\end{array}$ & On UI & Zero Earnings & Changed Firm & $\begin{array}{c}\text { Changed } \\
\text { 2-Digit } \\
\text { Industry }\end{array}$ & $\begin{array}{c}\text { Firm Avg. } \\
\text { Median Wage }\end{array}$ & $\begin{array}{l}\text { Firm Size } \\
>1000\end{array}$ & $\begin{array}{l}\text { Changed } \\
\text { Province }\end{array}$ \\
\hline Experience Group & \multicolumn{8}{|c|}{ Panel A: Log(Unemployment Rate Ages 15-24) } \\
\hline \multirow[t]{2}{*}{$0-10$} & -0.088 & 0.005 & 0.013 & -0.046 & -0.031 & -0.019 & 0.040 & -0.019 \\
\hline & $(0.027)$ & $(0.002)$ & $(0.003)$ & $(0.012)$ & $(0.010)$ & $(0.020)$ & $(0.009)$ & $(0.016)$ \\
\hline \multirow[t]{2}{*}{$0-1$} & -0.277 & 0.012 & 0.028 & 0.021 & 0.016 & -0.142 & -0.031 & 0.037 \\
\hline & $(0.035)$ & $(0.005)$ & $(0.004)$ & $(0.014)$ & $(0.013)$ & $(0.020)$ & $(0.011)$ & $(0.005)$ \\
\hline \multirow[t]{2}{*}{$2-3$} & -0.186 & 0.007 & 0.019 & -0.024 & -0.008 & -0.074 & 0.042 & -0.019 \\
\hline & $(0.030)$ & $(0.003)$ & $(0.004)$ & $(0.016)$ & $(0.013)$ & $(0.018)$ & $(0.011)$ & $(0.023)$ \\
\hline \multirow[t]{2}{*}{$4-5$} & -0.065 & 0.001 & 0.005 & -0.043 & -0.025 & 0.020 & 0.071 & -0.021 \\
\hline & $(0.028)$ & $(0.003)$ & $(0.003)$ & $(0.016)$ & $(0.013)$ & $(0.016)$ & $(0.011)$ & $(0.018)$ \\
\hline \multirow[t]{2}{*}{$6+$} & -0.037 & 0.000 & -0.001 & -0.061 & -0.043 & 0.050 & 0.058 & -0.019 \\
\hline & $(0.023)$ & $(0.002)$ & $(0.003)$ & $(0.017)$ & $(0.013)$ & $(0.019)$ & $(0.012)$ & $(0.017)$ \\
\hline Experience Group & \multicolumn{8}{|c|}{ Panel B: Log(Unemployment Rate All Ages) } \\
\hline \multirow[t]{2}{*}{$0-10$} & -0.115 & 0.005 & 0.012 & -0.041 & -0.026 & -0.043 & 0.025 & -0.016 \\
\hline & $(0.023)$ & $(0.002)$ & $(0.003)$ & $(0.012)$ & $(0.010)$ & $(0.015)$ & $(0.006)$ & $(0.016)$ \\
\hline \multirow[t]{2}{*}{$0-1$} & -0.276 & 0.009 & 0.024 & 0.026 & 0.020 & -0.150 & -0.038 & 0.038 \\
\hline & $(0.036)$ & $(0.005)$ & $(0.004)$ & $(0.014)$ & $(0.013)$ & $(0.022)$ & $(0.011)$ & $(0.006)$ \\
\hline \multirow[t]{2}{*}{$2-3$} & -0.188 & 0.007 & 0.018 & -0.022 & -0.005 & -0.098 & 0.029 & -0.024 \\
\hline & $(0.034)$ & $(0.004)$ & $(0.004)$ & $(0.017)$ & $(0.015)$ & $(0.018)$ & $(0.012)$ & $(0.023)$ \\
\hline \multirow[t]{2}{*}{$4-5$} & -0.086 & 0.003 & 0.005 & -0.048 & -0.028 & -0.005 & 0.055 & -0.027 \\
\hline & $(0.031)$ & $(0.003)$ & $(0.004)$ & $(0.017)$ & $(0.014)$ & $(0.018)$ & $(0.012)$ & $(0.019)$ \\
\hline \multirow[t]{2}{*}{$6+$} & -0.102 & 0.002 & 0.002 & -0.057 & -0.039 & 0.035 & 0.038 & -0.025 \\
\hline & $(0.028)$ & $(0.002)$ & $(0.003)$ & $(0.018)$ & $(0.013)$ & $(0.022)$ & $(0.014)$ & $(0.017)$ \\
\hline
\end{tabular}

Notes: Standard errors clustered at the province-cohort level are in parentheses. The unemployment rate refers to the unemployment rate in the region of current residence. Coefficients are from models ran separately by indicated group of potential experience. Controls include fixed effects for year, experience, first province, and current province. The unemployment rate for job-mobility is lagged by one period. In the case of linear probability models, year effects are replaced by quartic trends. 
Table 7: Heterogeneity in Initial Loss and Reversion by Worker Groups

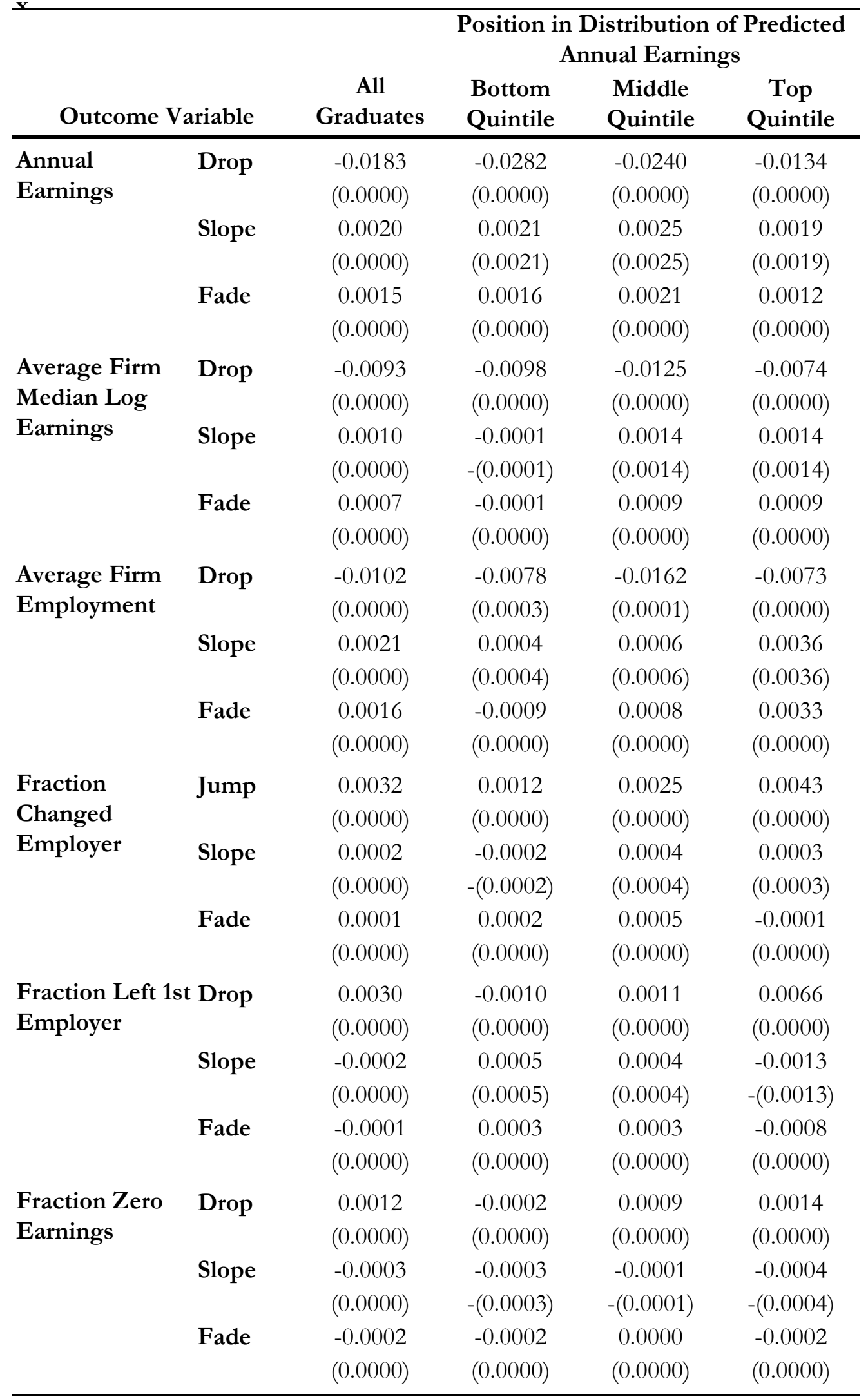

Notes: Coefficients from separate regression models. The initial loss (DROP) is the effect of unemployment at graduation (UR) at experience zero and one, the first phase of the catch up (SLOPE) is the coefficient on the interaction of UR with linear experience for experience years two to six, and the second phase (FADE) of the catch up is same interaction for experience years seven to ten. 
Figure 7: Changes of Earnings, Job Mobility, Firm Quality, and Employment due to Entering the Labor Market in a Recession for Workers with Different Predicted Earnings

Panel A: Log Real Annual Earnings

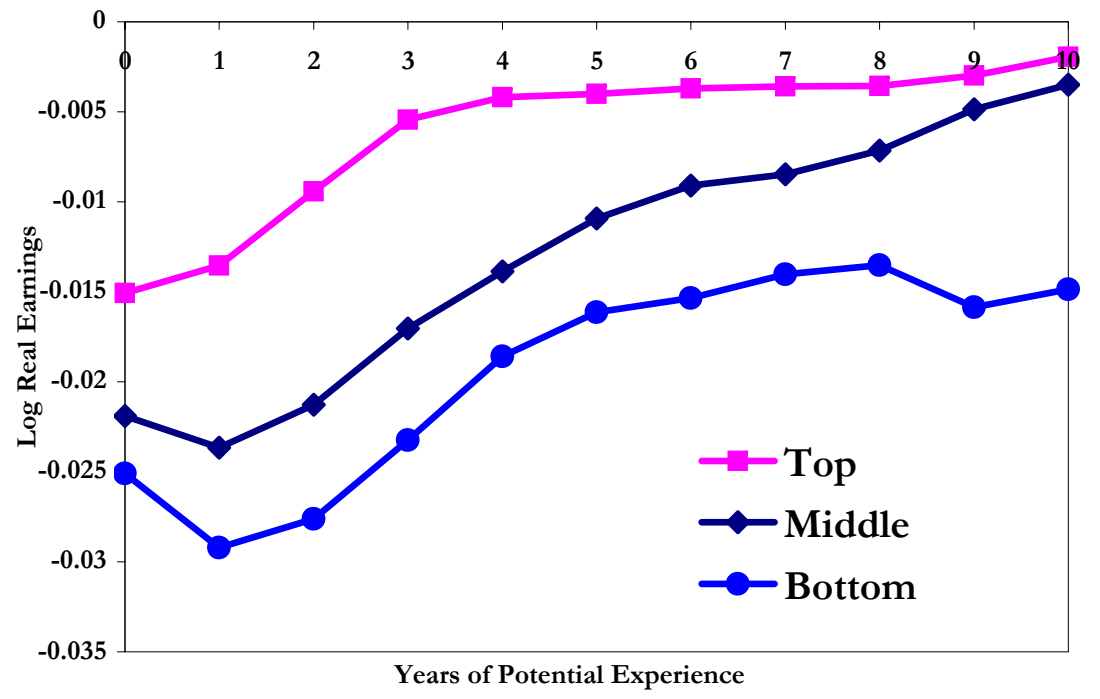

Panel C: Average Firm 'Quality', Graduates Only

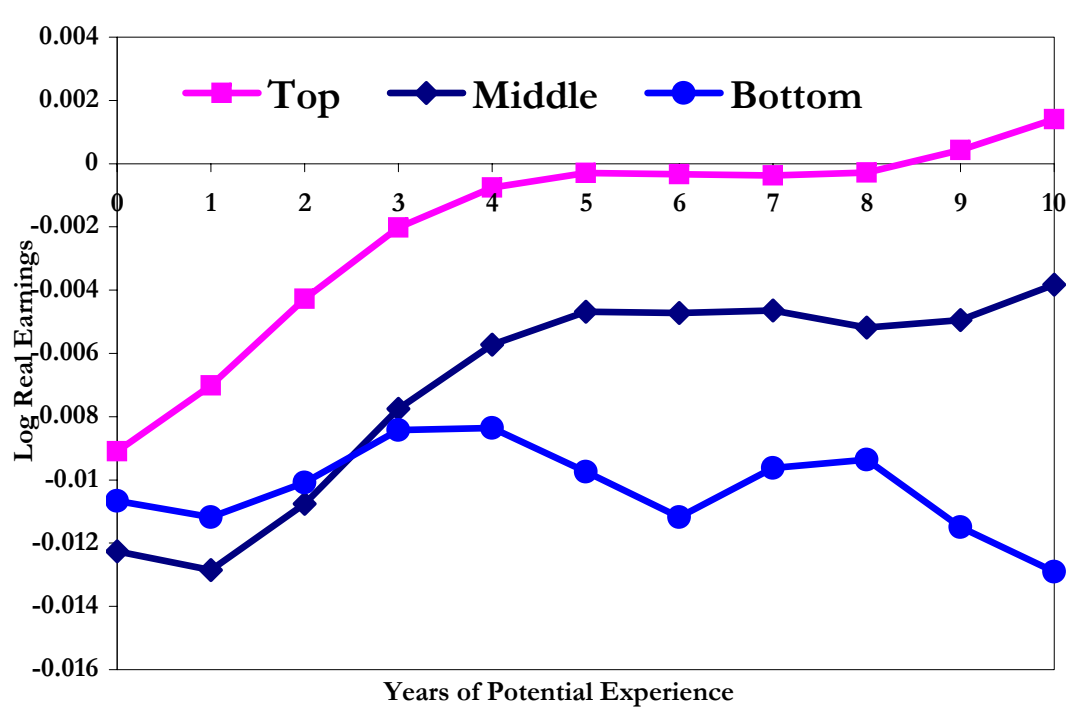

Panel B: Probability of Annual Change in Employers

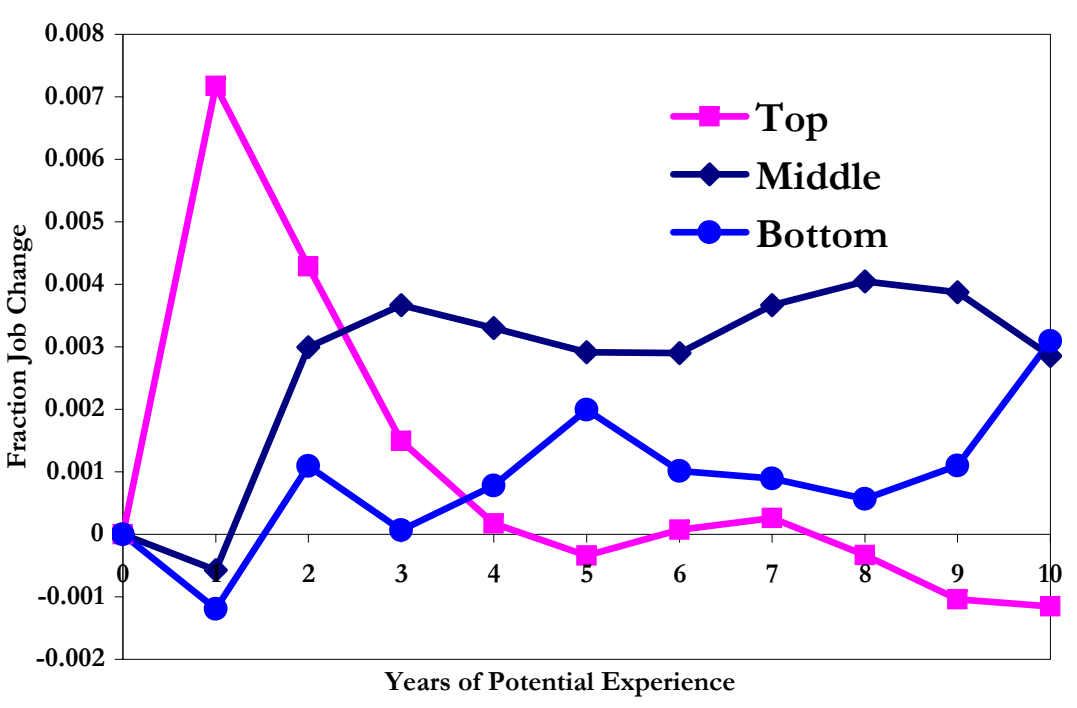

Panel D: Fraction Filing With Zero Annual Earnings

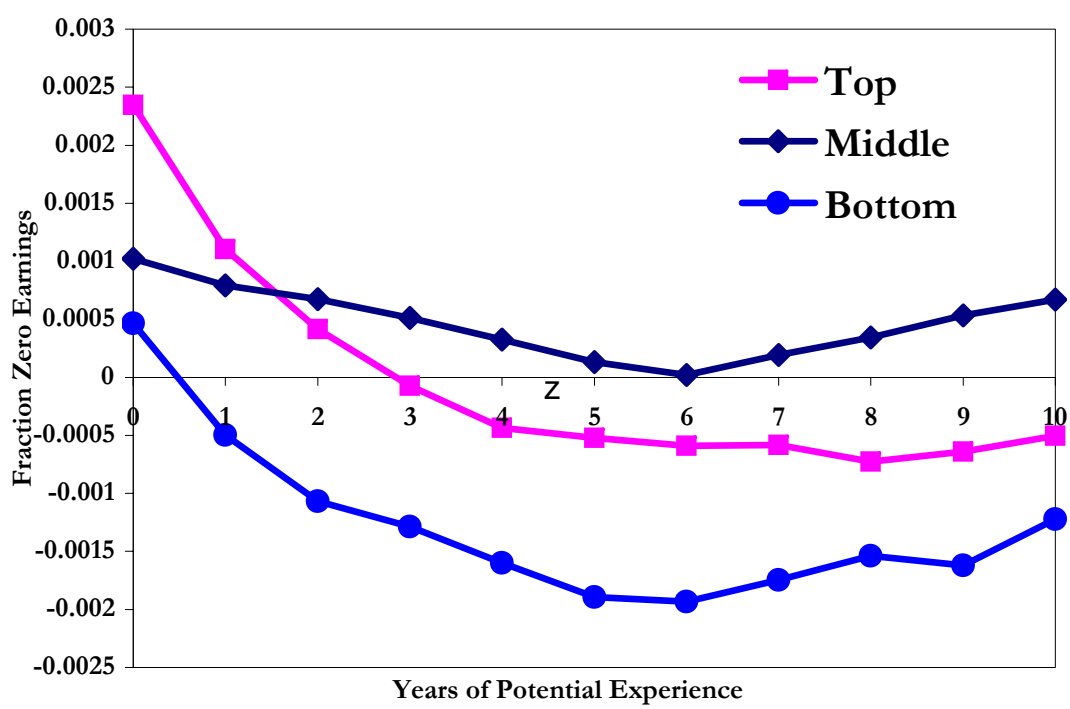


Figure 8: Heterogeneity of Losses from Graduating in a Recession and Channels of Catch-Up by Deciles of Distribution of Predicted Earnings

Panel A: Reversion of Losses After 5 Years in the Labor Market by Decile of Predicted Earning Distribution, College Graduates

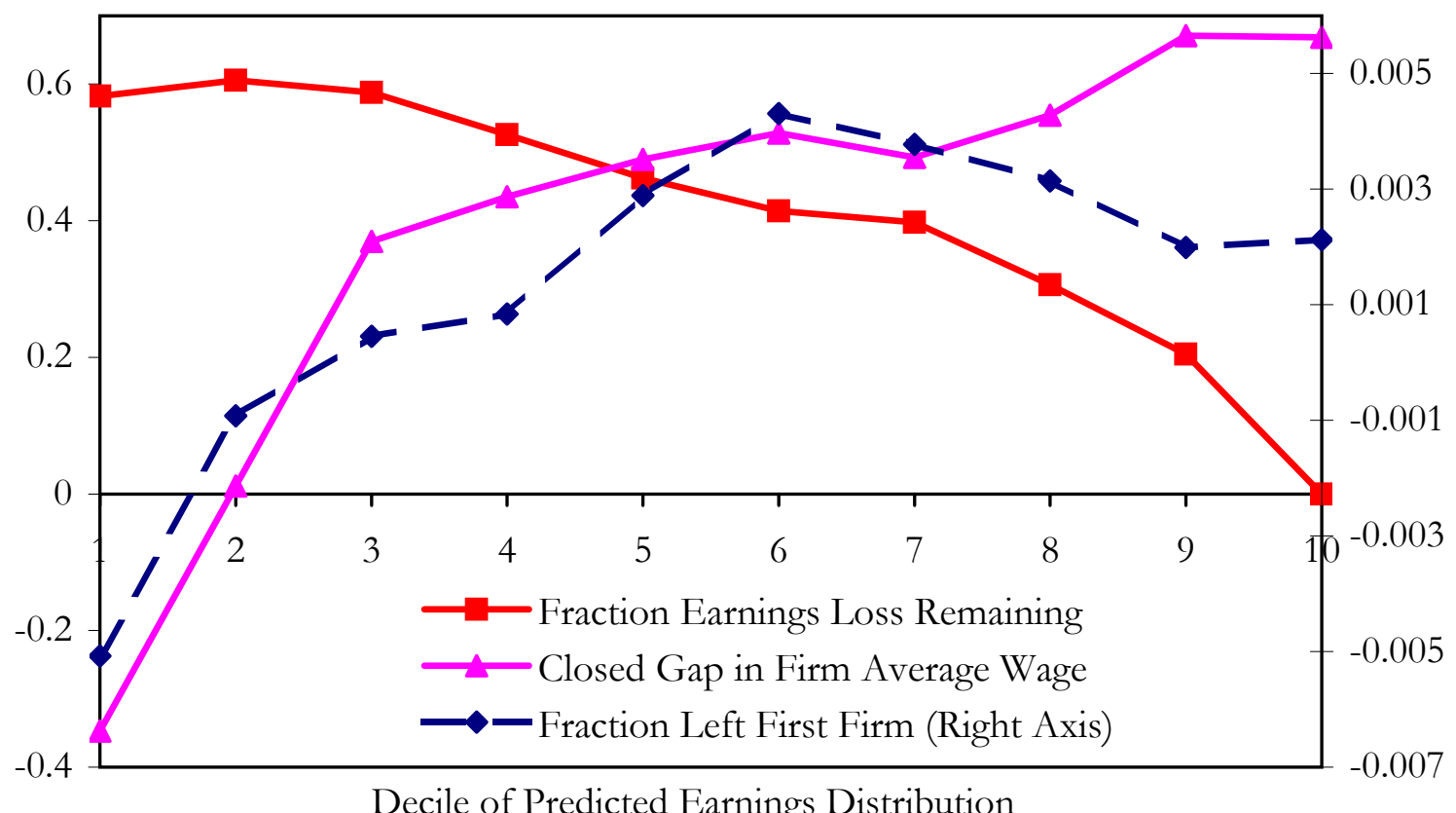

Panel B: Heterogeneity of Losses as Measured by Present Disctounted Value of Earnings or of Utility

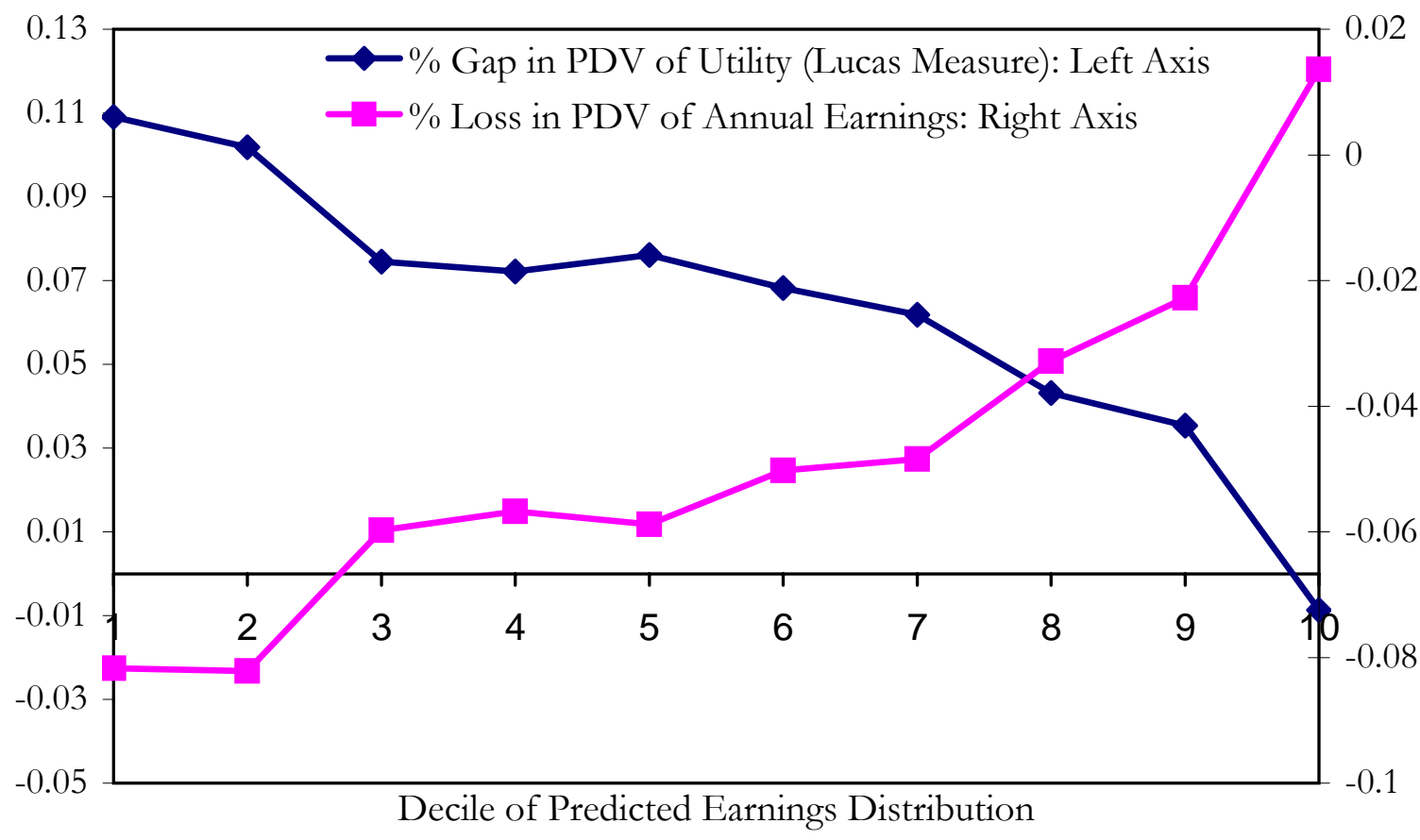


Appendix Table 1: Descriptive Statistics from Administrative College Data 1976-1995

\begin{tabular}{|c|c|c|c|c|c|c|c|c|}
\hline & \multicolumn{4}{|c|}{ Entire Sample (Some College) } & \multicolumn{4}{|c|}{ Graduates (Actual $\geq$ Predicted Year) } \\
\hline \multicolumn{9}{|c|}{ Panel A: Duration of College } \\
\hline & $\begin{array}{c}\text { Years Until } \\
\text { BA }\end{array}$ & $\begin{array}{c}\text { In } \\
\text { Graduate } \\
\text { Sample }\end{array}$ & $\begin{array}{c}\text { Fraction } \\
\text { Above } \\
\text { Grade }\end{array}$ & $\begin{array}{c}\text { Predicted- } \\
\text { Actual BA } \\
\text { Years }\end{array}$ & $\begin{array}{c}\text { Years Until } \\
\text { BA }\end{array}$ & $\begin{array}{c}\text { In } \\
\text { Graduate } \\
\text { Sample }\end{array}$ & $\begin{array}{c}\text { Fraction } \\
\text { Above } \\
\text { Grade }\end{array}$ & $\begin{array}{c}\text { Predicted- } \\
\text { Actual BA } \\
\text { Years }\end{array}$ \\
\hline \multirow{3}{*}{$\begin{array}{l}\text { At Exp. } \\
\text { Zero }\end{array}$} & 3.31 & 0.63 & 0.26 & -0.10 & 4.11 & 0.89 & 0.40 & 0.86 \\
\hline & $(1.29)$ & $(0.38)$ & $(0.37)$ & $(1.69)$ & $(0.59)$ & $(0.11)$ & $(0.39)$ & $(1.08)$ \\
\hline & $\begin{array}{c}\text { Fraction D } \\
\quad>1\end{array}$ & $\begin{array}{l}\text { Fraction D } \\
\quad>2\end{array}$ & $\begin{array}{c}\text { Fraction } \\
D<-1\end{array}$ & $\begin{array}{c}\text { Fraction } \\
D<-2\end{array}$ & $\begin{array}{c}\text { Fraction D } \\
\quad>0\end{array}$ & $\begin{array}{c}\text { Fraction D } \\
>1\end{array}$ & $\begin{array}{c}\text { Fraction D } \\
>2\end{array}$ & -- \\
\hline $\begin{array}{l}\text { At Exp. } \\
\text { Zero }\end{array}$ & 0.13 & 0.06 & 0.23 & 0.10 & 0.52 & 0.20 & 0.09 & -- \\
\hline \multicolumn{9}{|c|}{ Panel B: Unemployment Rates Ages 15-24 } \\
\hline & & & Average & $\begin{array}{c}\text { Standard } \\
\text { Deviation }\end{array}$ & Maximum & Minimum & & \\
\hline National & & & 14.76 & 2.42 & 19.2 & 11.0 & & \\
\hline Province & & & 14.13 & 3.98 & 32.7 & 6.3 & & \\
\hline National 1 & etrended & & 0 & 2.41 & 4.53 & -3.83 & & \\
\hline Province 1 & emeaned & & 0 & 3.01 & 6.53 & -7.12 & & \\
\hline \multirow{2}{*}{\multicolumn{2}{|c|}{ Panel C: Provinces }} & & \multicolumn{2}{|c|}{ Sample Size } & \multicolumn{4}{|c|}{ Unemployment Rate } \\
\hline & & & $\mathbf{N}$ & Fraction & & Average & Std. Dev. & \\
\hline Nova Sco & & & 1,143 & 0.84 & & 18.99 & 2.50 & \\
\hline PEI & & & 109 & 0.08 & & 18.91 & 2.08 & \\
\hline Newfounc & and & & 2,535 & 1.86 & & 27.11 & 3.51 & \\
\hline New Brun & wick & & 7,281 & 5.33 & & 20.07 & 2.13 & \\
\hline Quebec & & & 10,472 & 7.66 & & 17.20 & 2.60 & \\
\hline Ontario & & & 71,995 & 52.69 & & 13.03 & 3.14 & \\
\hline Manitoba & & & 10,308 & 7.54 & & 12.59 & 1.81 & \\
\hline Saskatche & $\operatorname{ran}$ & & 4,557 & 3.34 & & 11.84 & 2.26 & \\
\hline Alberta & & & 11,742 & 8.59 & & 11.68 & 3.08 & \\
\hline British Co & umbia & & 16,493 & 12.07 & & 15.93 & 3.86 & \\
\hline
\end{tabular}

Notes: See text and Data Appendix. D=Actual Graduation Year - Graduation Year Based on Program Duration. 
Appendix Table 2A. Sample Size by Graduation Cohort and Experience

\begin{tabular}{|c|c|c|c|c|c|c|c|c|c|c|c|c|}
\hline \multirow{2}{*}{$\begin{array}{c}\text { Graduation } \\
\text { Year }\end{array}$} & \multicolumn{11}{|c|}{ Years Since Graduation } & \multirow[b]{2}{*}{ Total } \\
\hline & $\mathbf{0}$ & 1 & 2 & 3 & 4 & 5 & 6 & 7 & 8 & 9 & 10 & \\
\hline 1976 & & & & & & & 3732 & 3732 & 3732 & 3732 & 3732 & 18660 \\
\hline 1977 & & & & & & 6875 & 6875 & 6875 & 6875 & 6875 & 6875 & 41250 \\
\hline 1978 & & & & & 7863 & 7863 & 7863 & 7863 & 7863 & 7863 & 7863 & 55041 \\
\hline 1979 & & & & 7780 & 7780 & 7780 & 7780 & 7780 & 7780 & 7780 & 7780 & 62240 \\
\hline 1980 & & & 7869 & 7869 & 7869 & 7869 & 7869 & 7869 & 7869 & 7869 & 7869 & 70821 \\
\hline 1981 & & 7899 & 7899 & 7899 & 7899 & 7899 & 7899 & 7899 & 7899 & 7899 & 7899 & 78990 \\
\hline 1982 & 8033 & 8033 & 8033 & 8033 & 8033 & 8033 & 8033 & 8033 & 8033 & 8033 & 8033 & 88363 \\
\hline 1983 & 9146 & 9146 & 9146 & 9146 & 9146 & 9146 & 9146 & 9146 & 9146 & 9146 & 9146 & 100606 \\
\hline 1984 & 8746 & 8746 & 8746 & 8746 & 8746 & 8746 & 8746 & 8746 & 8746 & 8746 & 8746 & 96206 \\
\hline 1985 & 9584 & 9584 & 9584 & 9584 & 9584 & 9584 & 9584 & 9584 & 9584 & 9584 & 9584 & 105424 \\
\hline 1986 & 9379 & 9379 & 9379 & 9379 & 9379 & 9379 & 9379 & 9379 & 9379 & 9379 & 9379 & 103169 \\
\hline 1987 & 9307 & 9307 & 9307 & 9307 & 9307 & 9307 & 9307 & 9307 & 9307 & 9307 & 9307 & 102377 \\
\hline 1988 & 9621 & 9621 & 9621 & 9621 & 9621 & 9621 & 9621 & 9621 & 9621 & 9621 & 9621 & 105831 \\
\hline 1989 & 9391 & 9391 & 9391 & 9391 & 9391 & 9391 & 9391 & 9391 & 9391 & 9391 & 9391 & 103301 \\
\hline 1990 & 9408 & 9408 & 9408 & 9408 & 9408 & 9408 & 9408 & 9408 & 9408 & 9408 & & 94080 \\
\hline 1991 & 9288 & 9288 & 9288 & 9288 & 9288 & 9288 & 9288 & 9288 & 9288 & & & 83592 \\
\hline 1992 & 9770 & 9770 & 9770 & 9770 & 9770 & 9770 & 9770 & 9770 & & & & 78160 \\
\hline 1993 & 10429 & 10429 & 10429 & 10429 & 10429 & 10429 & 10429 & & & & & 73003 \\
\hline 1994 & 14416 & 14416 & 14416 & 14416 & 14416 & 14416 & & & & & & 86496 \\
\hline 1995 & 10117 & 10117 & 10117 & 10117 & 10117 & & & & & & & 50585 \\
\hline Total & 136,635 & 144,534 & 152,403 & 160,183 & 168,046 & 164,804 & 154,120 & 143,691 & 133,921 & 124,633 & 115,225 & \\
\hline
\end{tabular}

Appendix Table 2B. Sample with Non-Missing Earnings by Graduation Cohort and Experience

\begin{tabular}{|c|c|c|c|c|c|c|c|c|c|c|c|c|}
\hline \multirow{2}{*}{$\begin{array}{c}\text { Graduation } \\
\text { Year }\end{array}$} & \multicolumn{11}{|c|}{ Years Since Graduation } & \multirow[b]{2}{*}{ Total } \\
\hline & 0 & 1 & 2 & 3 & 4 & 5 & 6 & 7 & 8 & 9 & 10 & \\
\hline 1976 & & & & & & & 3416 & 3364 & 3387 & 3367 & 3429 & 16963 \\
\hline 1977 & & & & & & 6320 & 6263 & 6322 & 6227 & 6303 & 6233 & 37668 \\
\hline 1978 & & & & & 7284 & 7199 & 7199 & 7073 & 7173 & 7050 & 7168 & 50146 \\
\hline 1979 & & & & 7119 & 7058 & 7088 & 6934 & 7026 & 6937 & 7032 & 7097 & 56291 \\
\hline 1980 & & & 7226 & 7134 & 7208 & 7073 & 7139 & 7041 & 7135 & 7194 & 7138 & 64288 \\
\hline 1981 & & 7166 & 7115 & 7160 & 7069 & 7097 & 7004 & 7102 & 7139 & 7131 & 7096 & 71079 \\
\hline 1982 & 7083 & 7204 & 7274 & 7170 & 7214 & 7131 & 7209 & 7287 & 7218 & 7201 & 7288 & 79279 \\
\hline 1983 & 7863 & 8144 & 8130 & 8249 & 8201 & 8221 & 8284 & 8221 & 8214 & 8221 & 8351 & 90099 \\
\hline 1984 & 7723 & 7796 & 7896 & 7763 & 7858 & 7906 & 7876 & 7774 & 7835 & 7895 & 7899 & 86221 \\
\hline 1985 & 8422 & 8637 & 8561 & 8637 & 8689 & 8672 & 8599 & 8616 & 8689 & 8693 & 8742 & 94957 \\
\hline 1986 & 8443 & 8456 & 8512 & 8557 & 8524 & 8440 & 8457 & 8475 & 8476 & 8560 & 8571 & 93471 \\
\hline 1987 & 8308 & 8428 & 8453 & 8375 & 8318 & 8311 & 8364 & 8383 & 8453 & 8473 & 8672 & 92538 \\
\hline 1988 & 8790 & 8776 & 8717 & 8661 & 8670 & 8658 & 8668 & 8746 & 8773 & 8854 & 9029 & 96342 \\
\hline 1989 & 8621 & 8530 & 8451 & 8433 & 8460 & 8411 & 8440 & 8557 & 8666 & 8785 & 9391 & 94745 \\
\hline 1990 & 8532 & 8454 & 8427 & 8421 & 8445 & 8452 & 8532 & 8658 & 8742 & 9408 & & 86071 \\
\hline 1991 & 8325 & 8300 & 8294 & 8302 & 8392 & 8410 & 8510 & 8632 & 9288 & & & 76453 \\
\hline 1992 & 8650 & 8707 & 8737 & 8806 & 8814 & 8895 & 9044 & 9770 & & & & 71423 \\
\hline 1993 & 9284 & 9389 & 9410 & 9371 & 9462 & 9650 & 10429 & & & & & 66995 \\
\hline 1994 & 12756 & 12863 & 12941 & 13160 & 13376 & 14416 & & & & & & 79512 \\
\hline 1995 & 9149 & 9152 & 9291 & 9403 & 10117 & & & & & & & 47112 \\
\hline Total & 121949 & 130002 & 137435 & 144721 & 153159 & 150350 & 140367 & 131047 & 122352 & 114167 & 106104 & \\
\hline
\end{tabular}


Appendix Table 3: Experience Profiles in Wages, Participation, and Job Change, Canada and USA

Entire Sample (Some College)

Graduates (Actual $\geq$ Predicted Year)

Panel A: Average Experience Profile Canada (Income Tax Records, 1982-1999)

\begin{tabular}{ccccccccc}
\hline $\begin{array}{c}\text { Year } \\
\text { of } \\
\text { Exp. }\end{array}$ & $\begin{array}{c}\text { Average } \\
\text { Log }\end{array}$ & $\begin{array}{c}\text { Fraction } \\
\text { En UI }\end{array}$ & $\begin{array}{c}\text { Frac. Not } \\
\text { in Labor } \\
\text { Force }\end{array}$ & $\begin{array}{c}\text { Fraction } \\
\text { Changed } \\
\text { Firm }\end{array}$ & $\begin{array}{c}\text { Average } \\
\text { Log } \\
\text { Earnings }\end{array}$ & $\begin{array}{c}\text { Fraction } \\
\text { on UI }\end{array}$ & $\begin{array}{c}\text { Frac. Not } \\
\text { in Labor } \\
\text { Force }\end{array}$ & $\begin{array}{c}\text { Fraction } \\
\text { Changed } \\
\text { Firm }\end{array}$ \\
\hline $\mathbf{0}$ & 8.83 & 0.016 & 0.111 & - & 8.93 & 0.020 & 0.102 & - \\
$\mathbf{1}$ & 9.30 & 0.023 & 0.103 & 0.42 & 9.49 & 0.020 & 0.094 & 0.40 \\
$\mathbf{2}$ & 9.51 & 0.023 & 0.100 & 0.35 & 9.71 & 0.020 & 0.093 & 0.31 \\
$\mathbf{3}$ & 9.69 & 0.021 & 0.099 & 0.31 & 9.87 & 0.016 & 0.093 & 0.28 \\
$\mathbf{4}$ & 9.84 & 0.017 & 0.091 & 0.28 & 9.99 & 0.013 & 0.085 & 0.25 \\
$\mathbf{5}$ & 9.96 & 0.016 & 0.090 & 0.25 & 10.10 & 0.012 & 0.085 & 0.22 \\
$\mathbf{6}$ & 10.05 & 0.015 & 0.092 & 0.22 & 10.18 & 0.011 & 0.086 & 0.20 \\
$\mathbf{7}$ & 10.13 & 0.013 & 0.090 & 0.20 & 10.25 & 0.009 & 0.084 & 0.18 \\
$\mathbf{8}$ & 10.20 & 0.012 & 0.089 & 0.18 & 10.30 & 0.008 & 0.082 & 0.17 \\
$\mathbf{9}$ & 10.25 & 0.011 & 0.086 & 0.17 & 10.36 & 0.007 & 0.082 & 0.16 \\
$\mathbf{1 0}$ & 10.30 & 0.010 & 0.081 & 0.17 & 10.40 & 0.007 & 0.077 & 0.16 \\
\hline
\end{tabular}

Panel B: Average Experience Profile USA (Current Population Survey 1994-1996)

\begin{tabular}{ccccccccc}
\hline $\begin{array}{c}\text { Year } \\
\text { of } \\
\text { Exp. }\end{array}$ & $\begin{array}{c}\text { Average } \\
\text { Log } \\
\text { Earnings }\end{array}$ & $\begin{array}{c}\text { Fraction } \\
\text { Unem- } \\
\text { ployed }\end{array}$ & $\begin{array}{c}\text { Frac. Not } \\
\text { in Labor } \\
\text { Force }\end{array}$ & $\begin{array}{c}\text { Fraction } \\
\text { Changed } \\
\text { Firm }^{\mathbf{a}}\end{array}$ & $\begin{array}{c}\text { Average } \\
\text { Log } \\
\text { Earnings }\end{array}$ & $\begin{array}{c}\text { Fraction } \\
\text { Unem- } \\
\text { ployed }\end{array}$ & $\begin{array}{c}\text { Frac. Not } \\
\text { in Labor } \\
\text { Force }\end{array}$ & $\begin{array}{c}\text { Fraction } \\
\text { Changed } \\
\text { Firm }^{\mathbf{a}}\end{array}$ \\
\hline $\mathbf{1}$ & 8.94 & 0.047 & 0.150 & 0.349 & 8.91 & 0.044 & 0.144 & 0.386 \\
$\mathbf{2}$ & 9.21 & 0.068 & 0.132 & 0.310 & 9.30 & 0.064 & 0.128 & 0.326 \\
$\mathbf{3}$ & 9.49 & 0.045 & 0.120 & 0.267 & 9.57 & 0.041 & 0.119 & 0.258 \\
$\mathbf{4}$ & 9.59 & 0.038 & 0.054 & 0.216 & 9.62 & 0.036 & 0.054 & 0.208 \\
$\mathbf{5}$ & 9.79 & 0.028 & 0.055 & 0.202 & 9.84 & 0.025 & 0.059 & 0.198 \\
$\mathbf{6}$ & 9.87 & 0.040 & 0.052 & 0.190 & 9.91 & 0.032 & 0.055 & 0.180 \\
$\mathbf{7}$ & 9.81 & 0.030 & 0.048 & 0.171 & 9.89 & 0.024 & 0.048 & 0.183 \\
$\mathbf{8}$ & 9.92 & 0.028 & 0.039 & 0.170 & 9.98 & 0.019 & 0.036 & 0.169 \\
$\mathbf{9}$ & 9.98 & 0.015 & 0.037 & 0.155 & 10.05 & 0.012 & 0.037 & 0.146 \\
$\mathbf{1 0}$ & 10.03 & 0.023 & 0.034 & 0.142 & 10.12 & 0.021 & 0.035 & 0.133 \\
\hline
\end{tabular}

Notes: See text and Data Appendix.

aThese figures are calculated as the fraction of workers with one year of tenure from the CPS' tenure, mobility, and pension supplements from 1979 to 2000. 
Appendix Table 4: Experience Profile in Mobility and Firm Characteristics, Canada 1982-1999, Graduates Only

Panel A. Mobility Outcomes by Potential Labor Market Experience

\begin{tabular}{|c|c|c|c|c|c|c|c|c|}
\hline \multirow[b]{2}{*}{$\begin{array}{l}\text { Year } \\
\text { of } \\
\text { Exp. }\end{array}$} & \multicolumn{8}{|c|}{ Difference $>=0$ (Graduates) } \\
\hline & $\begin{array}{l}\text { Fraction } \\
\text { Changed } \\
\text { Industry } 1\end{array}$ & $\begin{array}{c}\text { Fraction } \\
\text { Changed } \\
\text { Industry } 2\end{array}$ & $\begin{array}{c}\text { Fraction } \\
\text { Changed } \\
\text { Industry } 3\end{array}$ & $\begin{array}{l}\text { Fraction } \\
\text { Changed } \\
\text { Province }\end{array}$ & $\begin{array}{c}\text { Fraction } \\
\text { Left 1st } \\
\text { Firm }\end{array}$ & $\begin{array}{c}\text { Fraction } \\
\text { Left 1st } \\
\text { Industry } 1\end{array}$ & $\begin{array}{c}\text { Fraction } \\
\text { Left 1st } \\
\text { Industry } 2\end{array}$ & $\begin{array}{c}\text { Fraction } \\
\text { Left 1st } \\
\text { Province }\end{array}$ \\
\hline 0 & -- & -- & -- & -- & -- & -- & -- & -- \\
\hline 1 & 0.308 & 0.352 & 0.365 & 0.040 & 0.399 & 0.31 & 0.35 & 0.052 \\
\hline 2 & 0.220 & 0.257 & 0.270 & 0.029 & 0.558 & 0.42 & 0.48 & 0.086 \\
\hline 3 & 0.186 & 0.220 & 0.233 & 0.027 & 0.65 & 0.48 & 0.56 & 0.104 \\
\hline 4 & 0.163 & 0.194 & 0.207 & 0.024 & 0.709 & 0.52 & 0.61 & 0.115 \\
\hline 5 & 0.141 & 0.169 & 0.181 & 0.021 & 0.745 & 0.55 & 0.64 & 0.124 \\
\hline 6 & 0.126 & 0.151 & 0.163 & 0.020 & 0.769 & 0.56 & 0.66 & 0.133 \\
\hline 7 & 0.113 & 0.135 & 0.146 & 0.015 & 0.784 & 0.57 & 0.67 & 0.138 \\
\hline 8 & 0.104 & 0.124 & 0.134 & 0.012 & 0.799 & 0.58 & 0.68 & 0.143 \\
\hline 9 & 0.098 & 0.118 & 0.128 & 0.011 & 0.813 & 0.59 & 0.69 & 0.147 \\
\hline 10 & 0.098 & 0.116 & 0.126 & 0.009 & 0.827 & 0.61 & 0.71 & 0.150 \\
\hline
\end{tabular}

Panel B. Firm Outcomes by Potential Labor Market Experience

\begin{tabular}{|c|c|c|c|c|c|c|c|c|}
\hline \multirow[b]{2}{*}{$\begin{array}{l}\text { Year } \\
\text { of } \\
\text { Exp. }\end{array}$} & \multicolumn{8}{|c|}{ Difference $>=0$ (Graduates) } \\
\hline & $\begin{array}{c}\text { Mean Log } \\
\text { Firm Size }\end{array}$ & $\begin{array}{c}\text { Actual } \\
\text { Mean Firm } \\
\text { Size }\end{array}$ & $\begin{array}{c}\text { Fraction } \\
\text { Firm }>100\end{array}$ & $\begin{array}{c}\text { Fraction } \\
\text { Firm }>500\end{array}$ & $\begin{array}{c}\text { Fraction } \\
\text { Firm }> \\
1000\end{array}$ & $\begin{array}{c}\text { Fraction } \\
\text { Firm }> \\
5000\end{array}$ & $\begin{array}{l}\text { Avg. Log } \\
\text { Med. Firm } \\
\text { Earnings }\end{array}$ & $\begin{array}{c}\text { Avg. Log } \\
\text { Firm } \\
\text { Payroll }\end{array}$ \\
\hline 0 & 6.94 & 27705 & 0.73 & 0.59 & 0.53 & 0.34 & 0.62 & 5.94 \\
\hline 1 & 6.95 & 26563 & 0.74 & 0.59 & 0.53 & 0.33 & 0.70 & 6.00 \\
\hline 2 & 7.03 & 28549 & 0.75 & 0.60 & 0.54 & 0.33 & 0.76 & 6.14 \\
\hline 3 & 7.07 & 29701 & 0.75 & 0.61 & 0.55 & 0.34 & 0.81 & 6.22 \\
\hline 4 & 7.08 & 30210 & 0.75 & 0.61 & 0.55 & 0.34 & 0.84 & 6.26 \\
\hline 5 & 7.13 & 31429 & 0.76 & 0.62 & 0.55 & 0.35 & 0.87 & 6.34 \\
\hline 6 & 7.17 & 33207 & 0.76 & 0.62 & 0.56 & 0.36 & 0.89 & 6.41 \\
\hline 7 & 7.20 & 34164 & 0.76 & 0.63 & 0.56 & 0.36 & 0.91 & 6.45 \\
\hline 8 & 7.21 & 34981 & 0.76 & 0.63 & 0.56 & 0.37 & 0.92 & 6.48 \\
\hline 9 & 7.21 & 35286 & 0.76 & 0.63 & 0.57 & 0.37 & 0.93 & 6.50 \\
\hline 10 & 7.20 & 35810 & 0.76 & 0.63 & 0.57 & 0.37 & 0.94 & 6.50 \\
\hline
\end{tabular}

Notes: See text and Data Appendix. 
Appendix Table 5: Firm Size and Average Firm Wages Experience -- USA

\begin{tabular}{|c|c|c|c|c|c|c|c|c|}
\hline \multirow[b]{2}{*}{$\begin{array}{c}\text { Year of } \\
\text { Experience }\end{array}$} & \multicolumn{4}{|c|}{ All Workers (Some College) } & \multicolumn{4}{|c|}{ At Least 16 Years of Schooling } \\
\hline & $\begin{array}{l}\text { Log Firm } \\
\text { Size }\end{array}$ & $\begin{array}{l}\text { Fraction } \\
\text { Firm Size } \\
\quad>100\end{array}$ & $\begin{array}{l}\text { Fraction } \\
\text { Firm Size } \\
\quad>500\end{array}$ & $\begin{array}{c}\text { Fraction } \\
\text { Firm Size } \\
>1000\end{array}$ & $\begin{array}{l}\text { Log Firm } \\
\text { Size }\end{array}$ & $\begin{array}{c}\text { Fraction } \\
\text { Firm Size } \\
>100\end{array}$ & $\begin{array}{l}\text { Fraction } \\
\text { Firm Size } \\
\quad>500\end{array}$ & $\begin{array}{c}\text { Fraction } \\
\text { Firm Size } \\
>1000\end{array}$ \\
\hline 0 & 5.30 & 0.58 & 0.42 & 0.33 & 5.70 & 0.62 & 0.49 & 0.40 \\
\hline 1 & 5.16 & 0.52 & 0.40 & 0.33 & 5.65 & 0.61 & 0.47 & 0.40 \\
\hline 2 & 5.58 & 0.62 & 0.46 & 0.37 & 5.86 & 0.66 & 0.51 & 0.41 \\
\hline 3 & 5.43 & 0.59 & 0.42 & 0.34 & 5.52 & 0.59 & 0.44 & 0.36 \\
\hline 4 & 5.32 & 0.58 & 0.39 & 0.33 & 5.52 & 0.60 & 0.42 & 0.36 \\
\hline 5 & 5.65 & 0.61 & 0.47 & 0.36 & 5.89 & 0.64 & 0.50 & 0.40 \\
\hline 6 & 5.79 & 0.64 & 0.48 & 0.39 & 5.89 & 0.64 & 0.50 & 0.42 \\
\hline 7 & 5.70 & 0.63 & 0.48 & 0.38 & 5.80 & 0.65 & 0.50 & 0.39 \\
\hline 8 & 5.56 & 0.59 & 0.45 & 0.37 & 5.68 & 0.63 & 0.47 & 0.39 \\
\hline 9 & 5.96 & 0.67 & 0.51 & 0.44 & 6.18 & 0.71 & 0.54 & 0.46 \\
\hline 10 & 5.73 & 0.63 & 0.48 & 0.40 & 5.88 & 0.67 & 0.50 & 0.40 \\
\hline
\end{tabular}

Notes: Pension and Benefit Supplements to The Current Population Survey, 1979, 1983, 1988. Sample size is 4607

for all workers with 13 to 18 years of schooling and 2987 for workers with at least 16 years of schooling. 
Appendix Figure 1: Effect of Unemployment Rate at Time of Graduation on Log Real Earnings: Regional Graduate Models for Cohort 1982-1995 (Unless Otherwise Noted)

Panel A: Different Early Labor Market Conditions (2 Std.Dev. Shock)

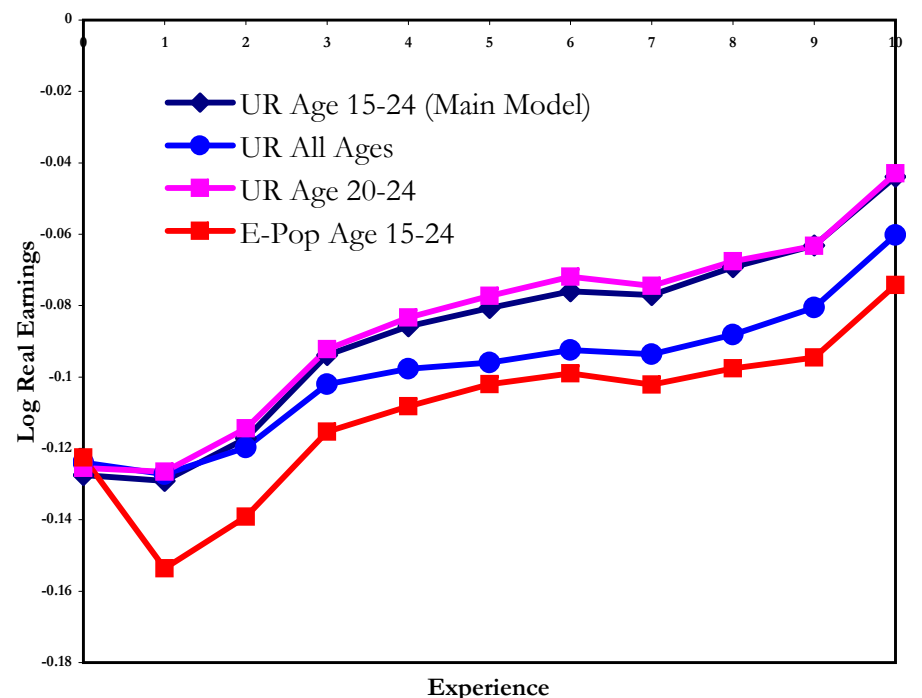

Panel C: Shock in Region of College vs. Region of First Residence

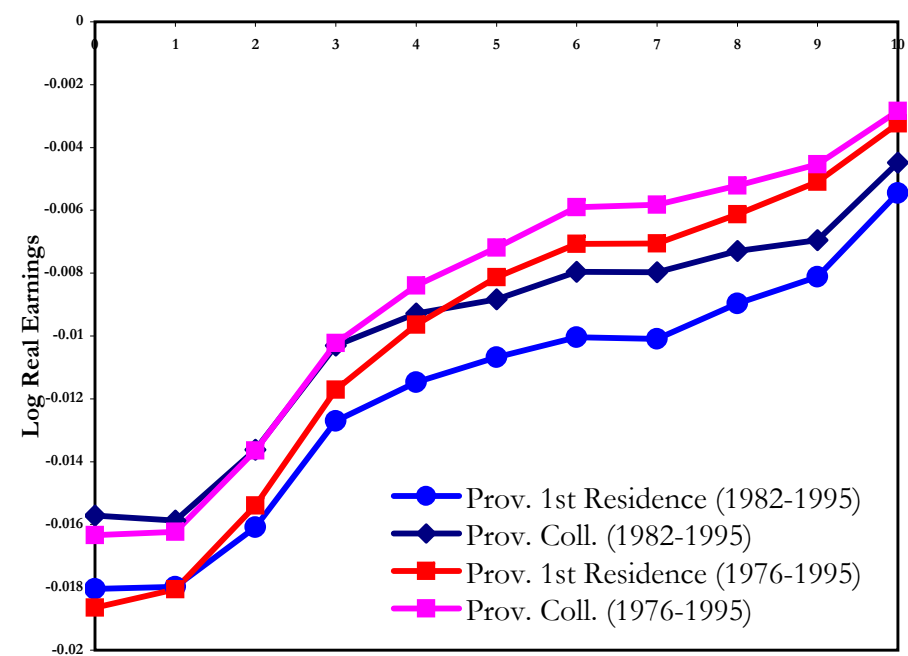

Experience
Panel B: Different Early Labor Market Horizons (Average UR)

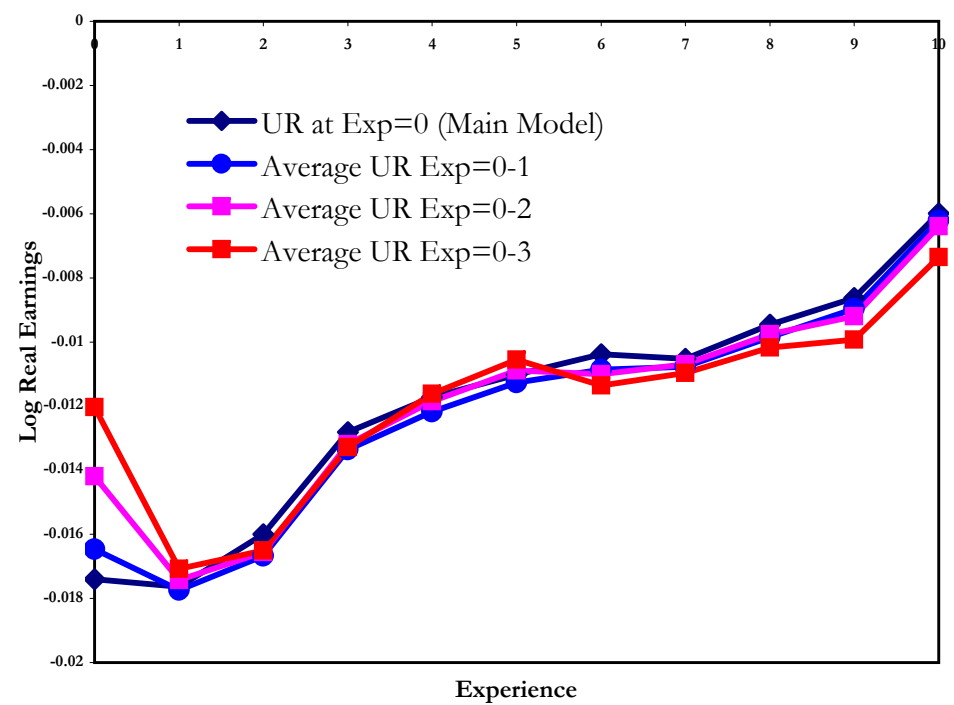

Panel D: Current Province and Current Province-Year Controls

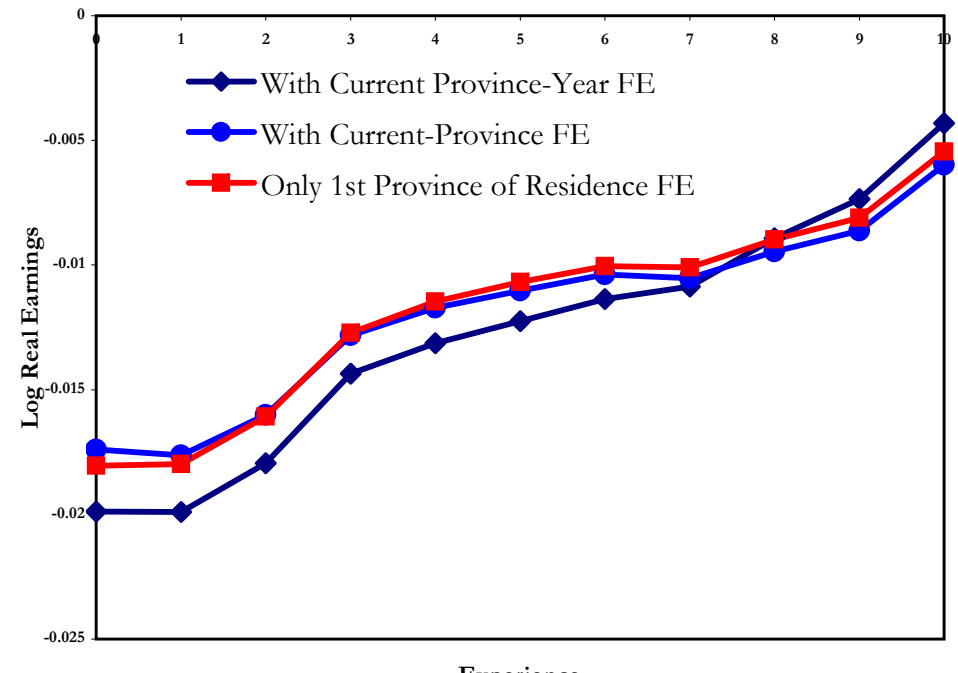

Experience 
Appendix Figure 2: Residuals of Separate Regressions of Earnings and Unemployment Rates including Year, First Province, and Graduation Cohort Dummies, Plotted by Experience Year with Corresponding Regression Line
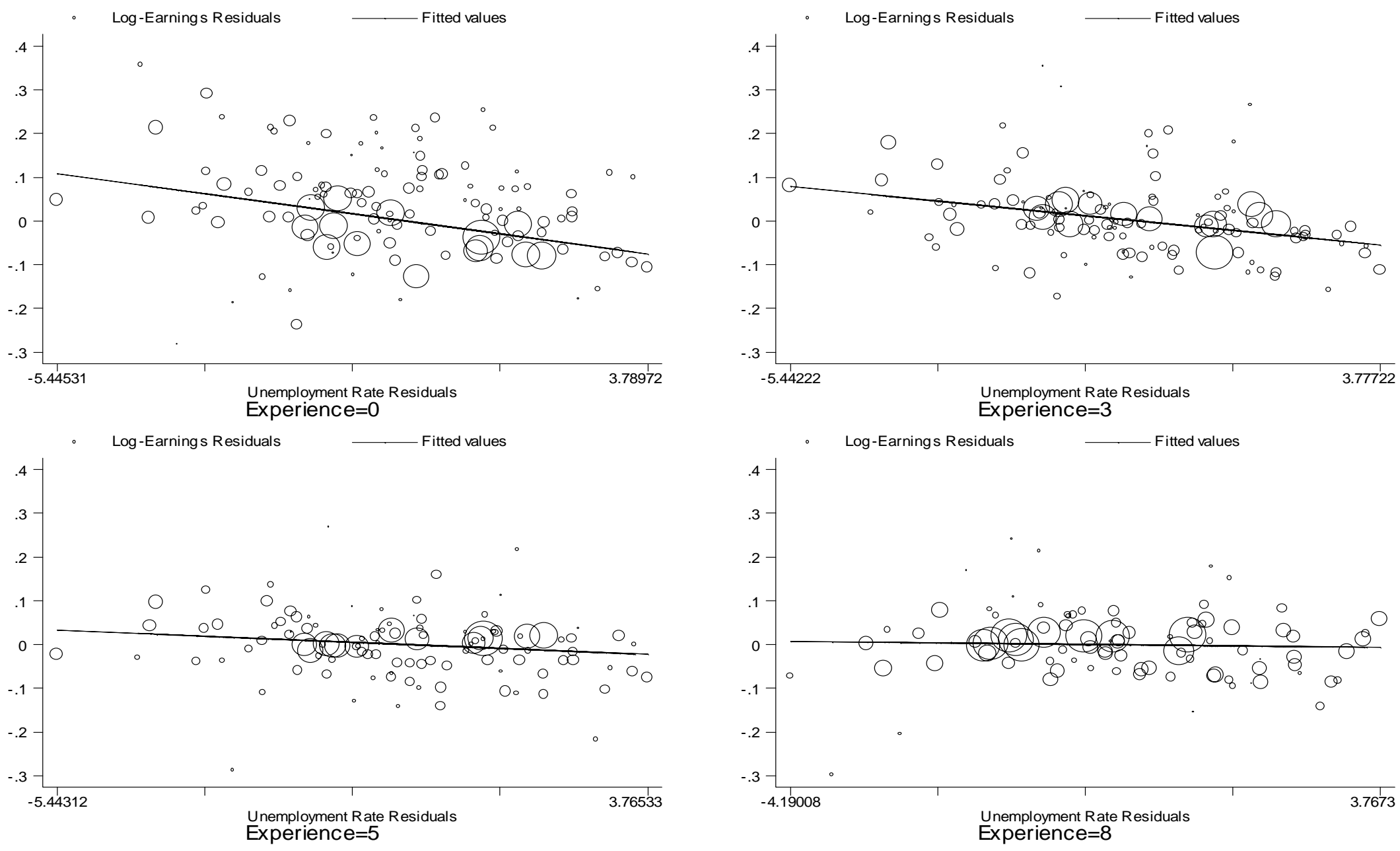

Notes: Circles correspond to cell sizes. 
Appendix Figure 3: Effect of Unemployment Rate at Time of Graduation on Log Real Earnings for Different Samples: Regional Models, Some College (All) and Graduate Sample, All Cohorts

Panel A: Including Workers Who Stop Filing

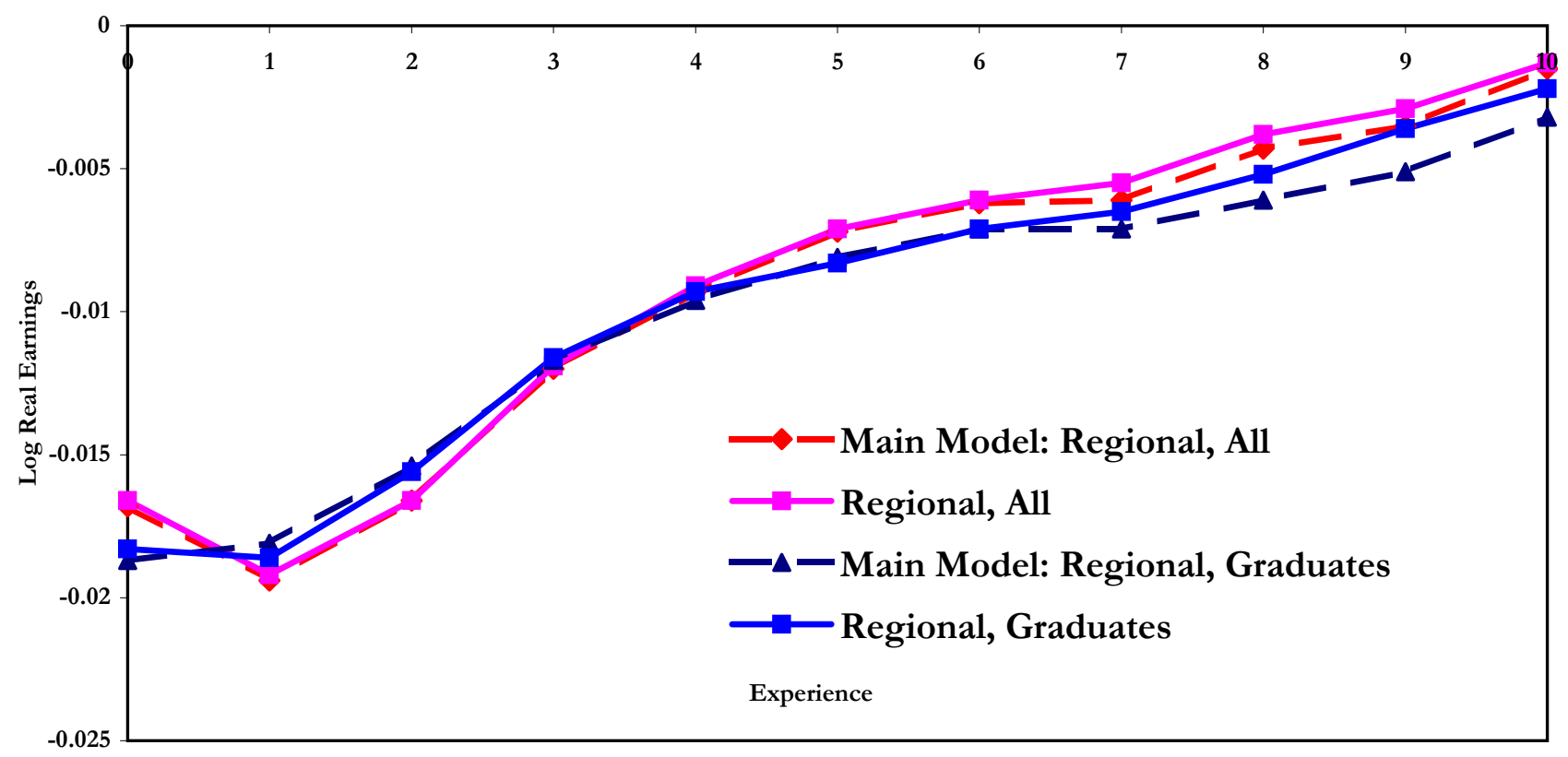

Panel B: Estimates for Sample Including Graduate Degrees

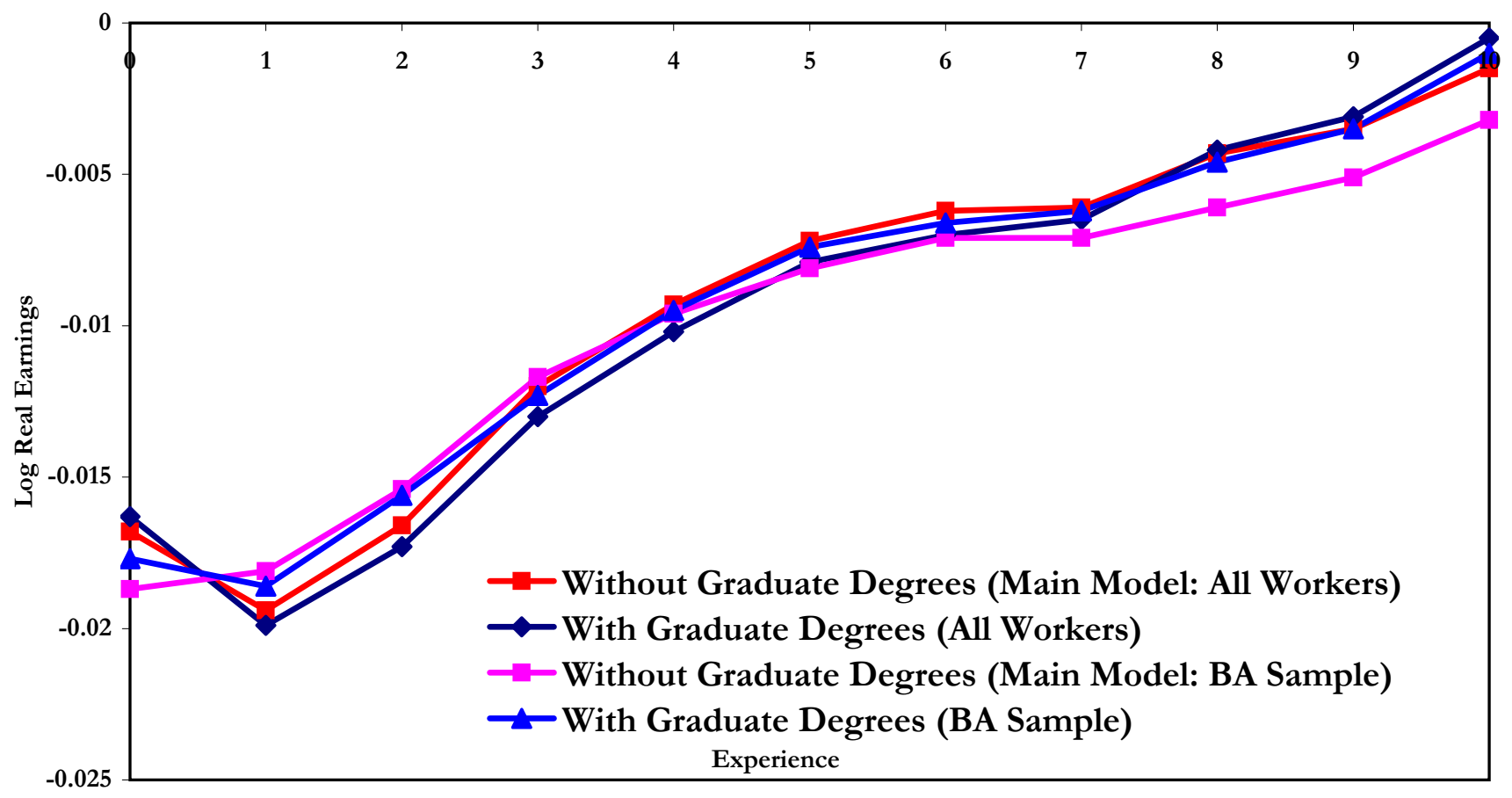




\begin{tabular}{|c|c|c|c|c|c|c|}
\hline & \multicolumn{6}{|c|}{ Specification } \\
\hline & \multirow{2}{*}{\multicolumn{2}{|c|}{$\begin{array}{l}\text { Fixed Effects for First } \\
\text { Firm/ Industry }\end{array}$}} & \multicolumn{2}{|c|}{$\begin{array}{c}\text { By Average Median Firm } \\
\text { Wage }\end{array}$} & \multicolumn{2}{|c|}{ By Average Log Firm Payrol } \\
\hline & & & Main Effect & Difference & Main Effect & Difference \\
\hline & Firm & Industry & $\begin{array}{c}<75 \text { th } \\
\text { Percentile }\end{array}$ & $\begin{array}{c}>=75 \text { th } \\
\text { Percentile }\end{array}$ & $\begin{array}{c}<75 \text { th } \\
\text { Percentile }\end{array}$ & $\begin{array}{c}>=75 \text { th } \\
\text { Percentile }\end{array}$ \\
\hline & (1) & (2) & (3) & (4) & (5) & (6) \\
\hline \multicolumn{7}{|c|}{ Experience Year } \\
\hline \multirow[t]{2}{*}{0} & -0.0091 & -0.0091 & -0.0146 & -0.0021 & -0.0157 & -0.0025 \\
\hline & {$[0.0033]^{* * *}$} & {$[0.0033]^{* * *}$} & {$[0.0028]^{* * *}$} & [0.0022] & {$[0.0028]^{* * *}$} & {$[0.0020]$} \\
\hline \multirow[t]{2}{*}{1} & -0.0111 & -0.0111 & -0.0159 & -0.0036 & -0.0159 & -0.0038 \\
\hline & {$[0.0028]^{* * *}$} & {$[0.0028]^{* * *}$} & {$[0.0026]^{* * *}$} & {$[0.0023]$} & {$[0.0024]^{* * *}$} & {$[0.0021]^{*}$} \\
\hline \multirow[t]{2}{*}{2} & -0.009 & -0.009 & -0.0134 & -0.0053 & -0.0136 & -0.0058 \\
\hline & {$[0.0027]^{* * *}$} & {$[0.0027]^{* * *}$} & {$[0.0024]^{* * *}$} & {$[0.0022]^{* *}$} & {$[0.0024]^{* * *}$} & {$[0.0021]^{* * *}$} \\
\hline \multirow[t]{2}{*}{3} & -0.0069 & -0.0069 & -0.0109 & -0.0051 & -0.0101 & -0.0068 \\
\hline & {$[0.0025]^{* * *}$} & {$[0.0025]^{* * *}$} & {$[0.0025]^{* * *}$} & {$[0.0023]^{* *}$} & {$[0.0023]^{* * *}$} & {$[0.0023]^{* * *}$} \\
\hline \multirow[t]{2}{*}{4} & -0.0051 & -0.0051 & -0.0096 & -0.0039 & -0.0096 & -0.0044 \\
\hline & {$[0.0027]^{*}$} & {$[0.0027]^{*}$} & {$[0.0020]^{* * *}$} & {$[0.0019]^{* *}$} & {$[0.0021]^{* * *}$} & {$[0.0018]^{* *}$} \\
\hline \multirow[t]{2}{*}{5} & -0.0032 & -0.0032 & -0.0082 & -0.0026 & -0.0088 & -0.0026 \\
\hline & [0.0024] & {$[0.0024]$} & {$[0.0018]^{* * *}$} & {$[0.0016]^{*}$} & {$[0.0020]^{* * *}$} & {$[0.0017]$} \\
\hline \multirow[t]{2}{*}{6} & -0.0031 & -0.0031 & -0.0067 & -0.0043 & -0.007 & -0.0041 \\
\hline & [0.0025] & {$[0.0025]$} & {$[0.0021]^{* * *}$} & {$[0.0017]^{* * *}$} & {$[0.0020]^{* * *}$} & {$[0.0017]^{* *}$} \\
\hline \multirow[t]{2}{*}{7} & -0.0027 & -0.0027 & -0.0052 & -0.0058 & -0.0069 & -0.0039 \\
\hline & [0.0027] & [0.0027] & {$[0.0019]^{* * *}$} & {$[0.0016]^{* * *}$} & {$[0.0019]^{* * *}$} & {$[0.0014]^{* * *}$} \\
\hline \multirow[t]{2}{*}{8} & -0.0005 & -0.0005 & -0.005 & -0.0033 & -0.0073 & -0.0006 \\
\hline & [0.0023] & [0.0023] & {$[0.0020]^{* *}$} & {$[0.0018]^{*}$} & {$[0.0021]^{* * *}$} & [0.0016] \\
\hline \multirow[t]{2}{*}{9} & -0.0013 & -0.0013 & -0.0036 & -0.006 & -0.0061 & -0.0013 \\
\hline & [0.0027] & [0.0027] & [0.0023] & {$[0.0017]^{* * *}$} & {$[0.0022]^{* * *}$} & [0.0020] \\
\hline \multirow[t]{2}{*}{10} & 0.0028 & 0.0028 & -0.0011 & -0.0049 & -0.0022 & -0.0034 \\
\hline & {$[0.0030]$} & {$[0.0030]$} & {$[0.0026]$} & {$[0.0016]^{* * *}$} & [0.0025] & [0.0021] \\
\hline \multirow[t]{2}{*}{ Constant } & 15.3696 & 15.3696 & 8.9546 & -- & 8.8768 & -- \\
\hline & {$[]$.} & [.] & {$[0.0908]^{* * *}$} & -- & {$[0.0664]^{* * *}$} & -- \\
\hline $\mathbf{N}$ & 418600 & 418600 & 12700 & -- & 14614 & -- \\
\hline R-squared & 0.8 & 0.8 & 0.93 & -- & 0.93 & -- \\
\hline
\end{tabular}

Note: First two columns indicate models with firm or industry fixed effects. The remainign columns display coefficients from two interacted regression models, respectively. Each columns shows the unemployment rate and experience interactions from regressing log annual earnings on the youth unemployment rate in the youth unemployment rate in the province of first residence, interacted with experience years 0 to 10, plus province of residence fixed effects, experience fixed effects, and year of graduation fixed effects. One, two, and three asterix indicates statistical significance at the 10 percent, 5 percent, and 1 percent levels respectively. See text for more details. 
Appendix Figure 4: Effect of Graduating in Recession on Annual Earnings by Major of Study (Graduates Only)

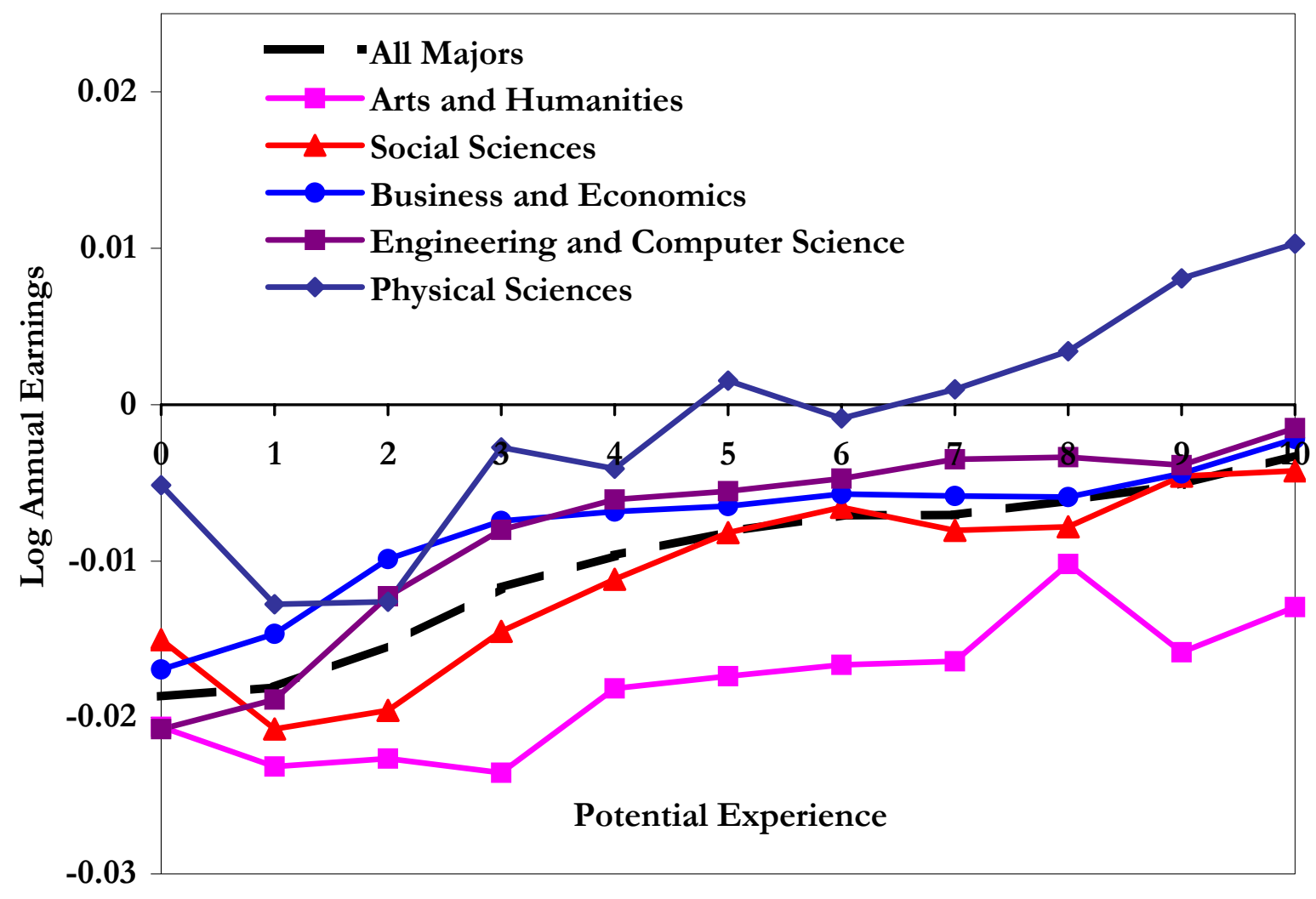


Appendix Table 7: Effect of Unemployment Rate on Duration of College -- National, Regional, and Predicted

\begin{tabular}{|c|c|c|c|c|c|c|}
\hline & $\begin{array}{c}\text { Years Until } \\
\text { BA }\end{array}$ & $\begin{array}{c}\text { Fraction } \\
\text { Above } \\
\text { Grade }\end{array}$ & $\begin{array}{c}\text { Fraction }<4 \\
\text { Years }\end{array}$ & $\begin{array}{c}\text { Fraction }>4 \\
\text { Years }\end{array}$ & $\begin{array}{c}\text { In Graduate } \\
\text { Sample }\end{array}$ & $\begin{array}{c}\text { Difference } \\
\text { (D) }\end{array}$ \\
\hline \multicolumn{7}{|c|}{ Panel A: National, All Workers } \\
\hline Unemployment Rate & $\begin{array}{c}0.007 \\
{[0.0138]}\end{array}$ & $\begin{array}{l}-0.0019 \\
{[0.0039]}\end{array}$ & $\begin{array}{l}-0.0018 \\
{[0.0039]}\end{array}$ & $\begin{array}{c}0.001 \\
{[0.0025]}\end{array}$ & $\begin{array}{c}0.0012 \\
{[0.0043]}\end{array}$ & $\begin{array}{l}-0.0006 \\
{[0.0157]}\end{array}$ \\
\hline $\mathbf{N}$ & 1591 & 1591 & 1591 & 1591 & 1591 & 1591 \\
\hline $\mathbf{R}^{2}$ & 0.01 & 0.02 & 0.01 & 0.02 & 0.01 & 0.02 \\
\hline
\end{tabular}

Panel B: Regional, All Workers

\begin{tabular}{ccccccc}
\hline Unemployment Rate & 0.0072 & 0.0046 & 0.0003 & 0.0041 & -0.0032 & 0.0034 \\
& {$[0.0074]$} & {$[0.0028]$} & {$[0.0024]$} & {$[0.0020]^{* *}$} & {$[0.0028]$} & {$[0.0108]$} \\
$\mathbf{N}$ & 1591 & 1591 & 1591 & 1591 & 1591 & 1591 \\
$\mathbf{R}^{2}$ & 0.08 & 0.05 & 0.06 & 0.09 & 0.09 & 0.06
\end{tabular}

Panel C: Regional, Predicted UR, All Workers

\begin{tabular}{cccccccc}
\hline Unemployment Rate & 0.0001 & -0.0003 & 0.0019 & 0.0025 & -0.0048 & -0.0042 \\
& {$[0.0410]$} & {$[0.0101]$} & {$[0.0115]$} & {$[0.0081]$} & {$[0.0112]$} & {$[0.0523]$} \\
$\mathbf{N}$ & 1566 & 1566 & 1566 & 1566 & 1566 & 1566 \\
$\mathbf{R}^{2}$ & 0.14 & 0.07 & 0.15 & 0.1 & 0.16 & 0.11
\end{tabular}

Panel D: National, D $>=0$

\begin{tabular}{ccccccc}
\hline Unemployment Rate & 0.0062 & -0.0025 & -0.0012 & 0.0017 & 0.0001 & -0.0052 \\
& {$[0.0063]$} & {$[0.0043]$} & {$[0.0010]$} & {$[0.0025]$} & {$[0.0014]$} & {$[0.0082]$} \\
$\mathbf{N}$ & 955 & 955 & 955 & 955 & 955 & 955 \\
$\mathbf{R}^{2}$ & 0.01 & 0.02 & 0.04 & 0.01 & 0 & 0.01
\end{tabular}

Panel E: Regional, D $>=0$

\begin{tabular}{cccccccc}
\hline Unemployment Rate & 0.011 & 0.0083 & -0.0002 & 0.0061 & -0.0007 & 0.0157 \\
& {$[0.0052]^{* *}$} & {$[0.0035]^{* *}$} & {$[0.0009]$} & {$[0.0027]^{* *}$} & {$[0.0015]$} & {$[0.0065]^{* *}$} \\
$\mathbf{N}$ & 955 & 955 & 955 & 955 & 955 & 955 \\
$\mathbf{R}^{2}$ & 0.22 & 0.04 & 0.27 & 0.15 & 0.38 & 0.04
\end{tabular}

Panel F: Regional, Predicted UR, D $>=0$

\begin{tabular}{ccccccc}
\hline Unemployment Rate & 0.006 & 0.0024 & -0.0001 & 0.0042 & -0.0002 & 0 \\
& {$[0.0042]$} & {$[0.0038]$} & {$[0.0008]$} & {$[0.0026]$} & {$[0.0016]$} & {$[0.0000]^{* * *}$} \\
$\mathbf{N}$ & 930 & 930 & 930 & 930 & 930 & 930 \\
$\mathbf{R}^{2}$ & 0.83 & 0.64 & 0.46 & 0.71 & 0.54 & 1 \\
\hline
\end{tabular}

Note: The sample includes males in Canada leaving university between 1976 and 1995. 'D' indicates the difference between the actual year left and the predicted year of graduation based on year of entry and program. The dependent variable is indicated in the column heading. The national model regresses the dependent variable on the youth unemployment rate in the country at the year of college exit, plus province of residence fixed effects, and a linear or quadratic graduation cohort trend. The regional model regresses log annual earnings on the youth unemployment rate in the province of first residence, plus province of residence fixed effects, and year of graduation fixed effects. One, two, and three asterix indicates statistical significance at the 10 percent, 5 percent, and 1 percent levels respectively. See text for more details. 
Appendix Table 8: Effect of Unemployment Rate at Time of Predicted Graduation on Log Real Earnings by Potential Experience (Reduced Form) and Instrumental Variable Estimates, Regional Model

\begin{tabular}{|c|c|c|c|c|}
\hline \multirow{4}{*}{$\begin{array}{l}\text { Model } \\
\mathrm{D}>=0 \text { ? }\end{array}$} & \multicolumn{4}{|c|}{ Specification } \\
\hline & \multicolumn{2}{|c|}{ Reduced Form } & \multicolumn{2}{|c|}{ Instrumental Variables } \\
\hline & No & Yes & No & Yes \\
\hline & (1) & (2) & (3) & (4) \\
\hline \multirow[t]{2}{*}{ First Stage Coefficient } & --- & --- & 0.8841 & 0.8984 \\
\hline & --- & --- & {$[0.0502]^{* * *}$} & {$[0.0391]^{* * *}$} \\
\hline \multicolumn{5}{|l|}{ Experience Year } \\
\hline \multirow[t]{2}{*}{$\mathbf{0}$} & -0.0119 & -0.0134 & -0.0162 & -0.0186 \\
\hline & {$[0.0023]^{* * *}$} & {$[0.0023]^{* * *}$} & {$[0.0030]^{* * *}$} & {$[0.0034]^{* * *}$} \\
\hline \multirow[t]{2}{*}{1} & -0.0154 & -0.0134 & -0.0215 & -0.0179 \\
\hline & {$[0.0030]^{* * *}$} & {$[0.0024]^{* * *}$} & {$[0.0041]^{* * *}$} & {$[0.0033]^{* * *}$} \\
\hline \multirow[t]{2}{*}{2} & -0.0145 & -0.0114 & -0.0204 & -0.0147 \\
\hline & {$[0.0030]^{* * *}$} & {$[0.0021]^{* * *}$} & {$[0.0042]^{* * *}$} & {$[0.0028]^{* * *}$} \\
\hline \multirow[t]{2}{*}{3} & -0.0117 & -0.0086 & -0.0165 & -0.0106 \\
\hline & {$[0.0027]^{* * *}$} & {$[0.0019]^{* * *}$} & {$[0.0038]^{* * *}$} & {$[0.0024]^{* * *}$} \\
\hline \multirow[t]{2}{*}{4} & -0.0093 & -0.0072 & -0.013 & -0.0086 \\
\hline & {$[0.0025]^{* * *}$} & {$[0.0019]^{* * *}$} & {$[0.0035]^{* * *}$} & {$[0.0023]^{* * *}$} \\
\hline \multirow[t]{2}{*}{5} & -0.0068 & -0.0059 & -0.0093 & -0.0069 \\
\hline & {$[0.0024]^{* * *}$} & {$[0.0017]^{* * *}$} & {$[0.0034]^{* * *}$} & {$[0.0021]^{* * *}$} \\
\hline \multirow[t]{2}{*}{6} & -0.0054 & -0.0045 & -0.0072 & -0.0053 \\
\hline & {$[0.0027]^{* *}$} & {$[0.0019]^{* *}$} & {$[0.0038]^{*}$} & {$[0.0024]^{* *}$} \\
\hline \multirow[t]{2}{*}{7} & -0.0059 & -0.0046 & -0.0079 & -0.0058 \\
\hline & {$[0.0026]^{* *}$} & {$[0.0018]^{* *}$} & {$[0.0036]^{* *}$} & {$[0.0023]^{* *}$} \\
\hline \multirow[t]{2}{*}{8} & -0.0053 & -0.0045 & -0.0073 & -0.0061 \\
\hline & {$[0.0024]^{* *}$} & {$[0.0018]^{* *}$} & {$[0.0034]^{* *}$} & {$[0.0023]^{* * *}$} \\
\hline \multirow[t]{2}{*}{9} & -0.0046 & -0.0041 & -0.0065 & -0.0056 \\
\hline & {$[0.0024]^{*}$} & {$[0.0020]^{* *}$} & {$[0.0034]^{*}$} & {$[0.0024]^{* *}$} \\
\hline \multirow[t]{2}{*}{10} & -0.0027 & -0.003 & -0.0043 & -0.0044 \\
\hline & {$[0.0025]$} & {$[0.0020]$} & {$[0.0034]$} & {$[0.0024]^{*}$} \\
\hline \multirow[t]{2}{*}{ Constant } & 6.9933 & 8.7117 & 7.0555 & 8.7857 \\
\hline & {$[0.1012]^{* * *}$} & {$[0.0668]^{* * *}$} & {$[0.0981]^{* * *}$} & {$[0.1075]^{* * *}$} \\
\hline $\mathbf{N}$ & 14223 & 8495 & 14223 & 8495 \\
\hline R-squared & 0.92 & 0.95 & 0.92 & 0.95 \\
\hline
\end{tabular}

Note: The sample includes males in Canada leaving university between 1976 and 1995. 'D' indicates the difference between the actual year left and the predicted year of graduation based on year of entry and program. The reduced form model regresses $\log$ annual earnings on the predicted youth unemployment rate in the province of first residence when $\mathrm{D}=0$, interacted with experience years 0 to 10 , plus province of residence fixed effects, experience fixed effects, and year of graduation fixed effects. The instrumental variable model regresses log annual earnings on the instrumented youth unemployment rate in the province of first residence, interacted with experience years 0 to 10 , plus province of residence fixed effects, experience fixed effects, and year of graduation fixed effects. One, two, and three asterix indicates statistical significance at the 10 percent, 5 percent, and 1 percent levels respectively. See text for more details. 